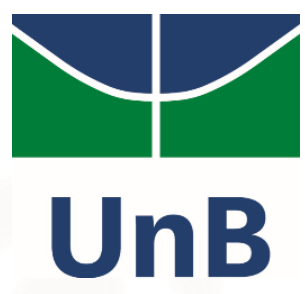

Universidade de Brasília - UnB Instituto de Ciências Humanas - IH Departamento de Geografia - GEA

Programa de Pós-Graduação em Geografia - PPGGEA Centro de Cartografia Aplicada e Informação Geográfica - CIGA

\title{
CARTOGRAFIA DA FORMAÇÃO TERRITORIAL DE ARAXÁ - MINAS GERAIS - DO SERTÃO KAYAPÓ AO TRIÂNGULO MINEIRO E ALTO PARANAÍBA - HERANÇAS HISTORIOGRÁFICAS E BASES DA GÊNESE NO TERRITÓRIO DE CONFLITO.
}

ROBERTA MARIA PORFÍRIO DE OLIVEIRA BORGES LEAL SANTOS Orientador: RAFAEL SANZIO ARAÚJO DOS ANJOS

Mestrado Acadêmico em Geografia 


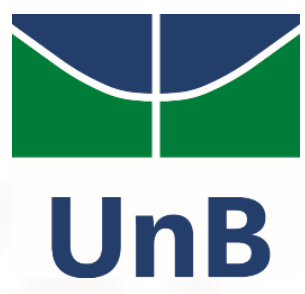

Universidade de Brasília - UnB Instituto de Ciências Humanas - IH

Departamento de Geografia - GEA

Programa de Pós-Graduação em Geografia - PPGGEA

Centro de Cartografia Aplicada e Informação Geográfica - CIGA

\section{CARTOGRAFIA DA FORMAÇÃO TERRITORIAL DE ARAXÁ - MINAS GERAIS - DO SERTÃO KAYAPÓ AO TRIÂNGULO MINEIRO E ALTO PARANAÍBA - HERANÇAS HISTORIOGRÁFICAS E BASES DA GÊNESE NO TERRITÓRIO DE CONFLITO.}

ROBERTA MARIA PORFÍRIO DE OLIVEIRA BORGES LEAL SANTOS Orientador: RAFAEL SANZIO ARAÚJO DOS ANJOS

Mestrado Acadêmico em Geografia Área de Concentração: Gestão Ambiental e Territorial Linha de Pesquisa 3: Produção do Espaço Urbano, Rural e Regional

DisSERTAÇÃo

Brasília - DF: Fevereiro/ 2018 


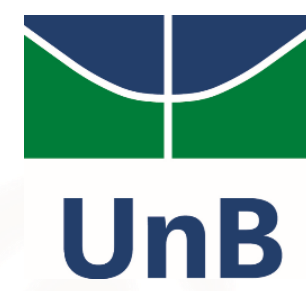

Universidade de Brasília - UnB Instituto de Ciências Humanas - IH

Departamento de Geografia - GEA

Programa de Pós-Graduação em Geografia - PPGGEA

Centro de Cartografia Aplicada e Informação Geográfica - CIGA

\section{CARTOGRAFIA DA FORMAÇÃO TERRITORIAL DE ARAXÁ - MINAS GERAIS - DO SERTÃo KAYAPÓ AO TRIÂNGULO MINEIRO E ALTO PARANAÍBA - HERANÇAS HISTORIOGRÁFICAS E BASES DA GÊNESE NO TERRITÓRIO DE CONFLITO.}

ROBERTA MARIA PORFÍRIO DE OLIVEIRA BORGES LEAL SANTOS

Dissertação de Mestrado submetida ao Departamento de Geografia da Universidade de Brasília, como parte dos requisitos necessários para a obtenção do Grau de Mestre em Geografia, área de concentração Gestão Ambiental e Territorial, opção Acadêmica.

Aprovado por:

Dr. Rafael Sanzio Araújo dos Anjos, Professor Titular do Departamento de Geografia da Universidade de Brasília - UnB (Orientador)

Dr. Neio Lúcio de Oliveira Campos, Professor do Departamento de Geografia da Universidade de Brasília - UnB (Examinador Interno)

Dra. Valéria Nely Cézar de Carvalho, Pós-Doutora em História pela Universidade de São Paulo - USP

(Examinador Externo)

Brasília-DF, 01 de fevereiro de 2018. 


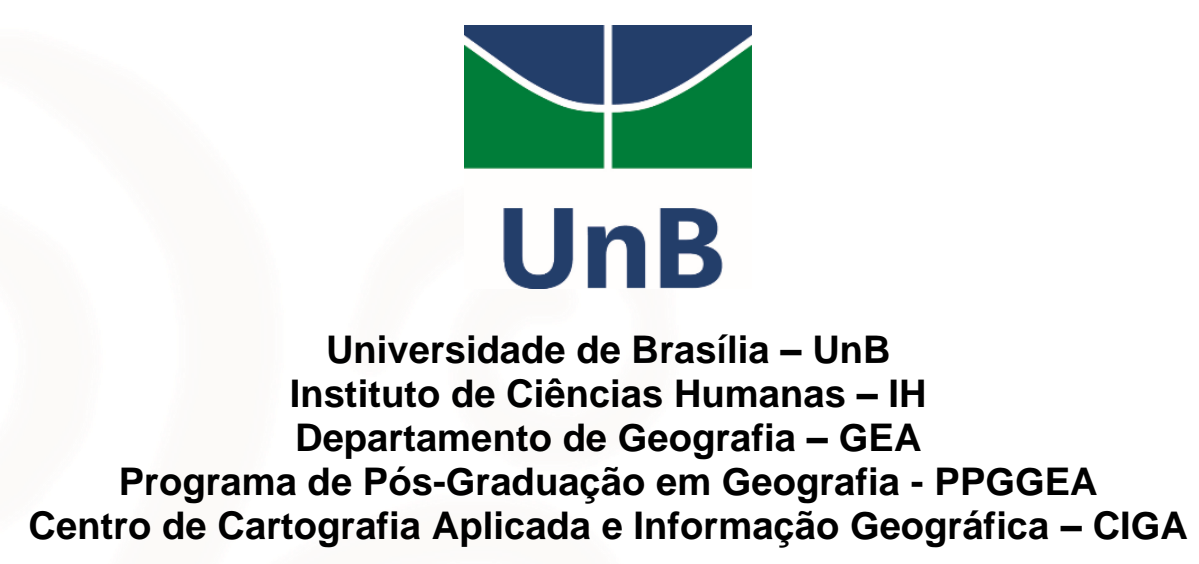

BORGES, ROBERTA MARIA PORFIRIO DE OLIVEIRA

Cartografia da Formação Territorial de Araxá - Minas Gerais - do Sertão Kayapó ao Triângulo Mineiro e Alto Paranaíba - Heranças Historiográficas e Bases da Gênese no Território de Conflito, 145 p., 297 mm, (UnB-GEA, Mestre, Gestão Ambiental e Territorial, 2018).

Dissertação de Mestrado - Universidade de Brasília. Departamento de Geografia.
1. Cartografia
2. Formação Territorial
3. Conflitos
4. Território
I. UnB-GEA
II. Título (série)

É concedida à Universidade de Brasília permissão para reproduzir cópias desta dissertação e emprestar ou vender tais cópias somente para propósitos acadêmicos e científicos. $O$ autor reserva outros direitos de publicação e nenhuma parte desta dissertação de mestrado pode ser reproduzida sem a autorização por escrito do autor. 
Dedico esta pesquisa primeiramente a Deus, meu Senhor, a quem louvo e glorifico com esta realização.

Ao meu Marido, Vitor Laércio de Sá Leal Santos, que com tanto carinho e paciência esteve ao meu lado nesta jornada.

À minha Mamãe, Maria Luzia Borges, que me deu todo o apoio, amor e não mediu esforços para que eu chegasse nesta etapa de minha vida. 


\section{Agradecimentos}

Ao Centro de Cartografia Aplicada e Informação Geográfica - CIGA/GEA/UnB e toda a equipe CIGA e de orientandos do Professor Rafael por todo o apoio, suporte e aprendizado.

Ao Professor Rafael Sanzio Araújo dos Anjos, pela orientação, pela generosidade acadêmica, pelo apoio, pelo suporte do CIGA, pelo apoio técnico, pela atenção, pela ajuda, pela paciência e por ter confiado em mim e na minha pesquisa.

À minha Banca de Qualificação, Professoras Valéria Nely Cezar Carvalho e Glória Maria Vargas pelos valiosos apontamentos e considerações.

Ao Professor Neio Lúcio de Oliveira Campos pelo incentivo, pelos esclarecimentos e considerações.

Ao meu Marido, Vitor Laércio de Sá Leal Santos, pelos cafés da manhã na cama, pelas vitaminas de frutas, pelos lanches e refeições que fizeram toda a diferença na minha rotina de pesquisa. Agradeço também pelas inúmeras refeições que fez comigo no Restaurante Universitário me apoiando e me fazendo companhia. Agradeço ainda pela ajuda nas traduções para a língua inglesa e pela serenidade e racionalidade nos momentos críticos de realização da pesquisa.

A minha Mamãe, Maria Luzia Borges, pelo apoio, pela torcida, pela proteção, pelo incentivo constante e por ter viabilizado que eu fosse em frente ao ter me dado tanta força nas tarefas domésticas quando eu não conseguia concilia-las com a pesquisa.

A minha Titia Lena, Helena de Oliveira Borges, que me deu o computador e a licença do pacote Office que utilizei na realização desta pesquisa.

Ao meu Tio Renato, Aluyzio Renato Porfírio Borges (in memoriam) que me deixou recursos para os suprimentos finais desta pesquisa.

A todos os familiares, parentes e amigos que, estando geograficamente perto ou longe, sempre torceram por mim.

A Deus por ter me abençoado colocando essas pessoas em minha vida. 
“A geograficidade se impõe como condição histórica, na medida em que nada considerado essencial hoje se faz no mundo que não seja a partir do conhecimento do que é o Território".

(SANTOS, Milton. 1999) 


\section{RESUMO}

A Formação Territorial de Araxá é processo que reflete e representa uma referência pragmática ao grande processo de formação territorial brasileiro em dialética com os processos, ciclos e sistemas que, de forma multiescalar, representam o mundo no movimento do espaço que define o território e as dinâmicas territoriais ao longo do tempo. Pesquisa tem como objetivo principal analisar o processo de Formação territorial de Araxá - Minas Gerais - no território, com a utilização da Cartografia Histórica, além dos dados históricos e da historiografia, para a construção da base de dados da pesquisa e para a construção da Cartografia da Formação Territorial de Araxá. O objeto é tratado em dialética com a estrutura do contexto global. A partir da definição do Referencial da Área de Estudo na Cartografia Histórica e o levantamento e utilização da Cartografia Histórica como referência e fonte de dados para a pesquisa, foi realizada a reconstrução do contexto histórico, político, geográfico e bélico que permeava a Região de Araxá desde o período em que a região era parte do Sertão do Gentio Kayapó, antes de neste território passar a funcionar o colonial Sertão da Farinha Podre, hoje Triângulo Mineiro, até o início do Núcleo Urbano de Araxá neste território de conflito. Então é realizada uma reconstrução, projeção e representação cartográfica da evolução administrativa da região de Araxá desde o "Antigo Município de Araxá" até a atualidade, com a identificação de todos os municípios oriundos do seu território. O produto principal da pesquisa é a Cartografia da Formação Territorial de Araxá, realizada em documentos articulados, mas independentes, sendo, portanto, cada um capaz de isoladamente prestar o entendimento as informações nele tratadas. Os produtos cartográficos desta pesquisa apresentam a espacialização de elementos do processo que possibilitam a visualização, ao longo do tempo histórico, de fases, dinâmicas e processos da Formação Territorial de Araxá e de outras unidades territoriais envolvidas, como por exemplo, os 76 municípios oriundos do Território do Antigo Araxá (todo o território da Mesorregião do Triângulo Mineiro e Alto Paranaíba - 66 Municípios - além de partes das Mesorregiões do Noroeste de Minas - Presidente Olegário, São Gonçalo do Abaeté, Lagamar, Lagoa Grande e Varjão de Minas - e Central Mineira - Abaeté, Morada Nova de Minas, Biquinhas, Paineiras e Cedro do Abaeté) ou ainda de núcleos urbanos de gênese colonial oriundos do território da Comarca do Rio das Mortes. 
PALAVRAS-CHAVE: Cartografia, Formação Territorial, Araxá, Triângulo Mineiro, Cartografia Histórica, Território, Conflito, Dinâmica Territorial, Colonização.

\section{ABStrACT}

The Territorial Formation of Araxá is a process that reflects and represents a pragmatic reference to the great process of Brazilian territorial formation in dialectics with processes, cycles and systems that, in a multi-scale way, represent the world in the movement of space that defines territory and dynamics in the course of historical time. The main objective of this research is to analyze the process of Territorial Formation of Araxá - Minas Gerais - in the territory, with the use of Historical Cartography, as well as historical data and historiography, for the construction of the research database and for the construction of Cartography of the Territorial Formation of Araxá. The object is treated in dialectic with the global contexto structure. From the definition of the Reference Area of the Study Area in Historical Cartography and the survey and use of Historical Cartography as a reference and data source for the research, the historical, political, geographic and war context that permeated the Region of Araxá from the period when the region was part of the Gentile Kayapó Sertão, before in this territory the colonial Sertão do Farinha Podre, now known as Triângulo Mineiro, began to function until the beginning of the Urban Nucleus of Araxá in this territory of conflict. Then a reconstruction, projection and cartographic representation of the administrative evolution of the region of Araxá from the "Old Municipality of Araxá" is carried out until today, with the identification of all the municipalities coming from its territory. The main product of the research is the Cartography of the Territorial Formation of Araxá, carried out in articulated but independent documents, and therefore, each one is capable of providing the information in isolation. The cartographic products of this research present the spatialisation of elements of the process that make it possible to visualize, during historical time, the phases, dynamics and processes of the Territorial Formation of Araxá and other territorial units involved, such as the 76 municipalities originating in Territory of the Ancient Araxá (all the territory of the Mesoregion of the Triângulo Mineiro and Alto Paranaíba - 66 Municipalities - in addition to parts of the Mesoregions of the Noroeste de Minas - Presidente Olegário, São Gonçalo do Abaeté, Lagamar, Lagoa Grande and Varjão de Minas - and Central Mineira - Abaeté, Morada Nova de 
Minas, Biquinhas, Paineiras and Cedro do Abaeté) or of urban nuclei of colonial genesis originating from the territory of the Comarca of Rio das Mortes.

KEYWORDS: Cartography, Territorial Formation, Araxá, Triângulo Mineiro, Historical Cartography, Territory, Conflict, Territorial Dynamics, Colonization 


\section{SUMÁRIO}

INTRODUÇÃO

Capítulo I - Procedimentos Metodológıcos e FundamentaÇão Teórica.................................18

PROCEDIMENTOS METODOLÓGICOS .............................................................................

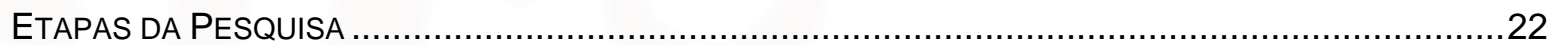

FUNDAMENTAÇÃO TEÓRICA E PRINCIPAIS CONCEITOS ............................................................27

PRINCIPAIS REFERÊNCIAS CARTOGRÁFICAS COLONIAIS E IMPERIAIS..........................................38

A CARTOGRAFIA HISTÓRICA COMO REFERÊNCIA E FONTE DE DADOS NA PESQUISA .........................49

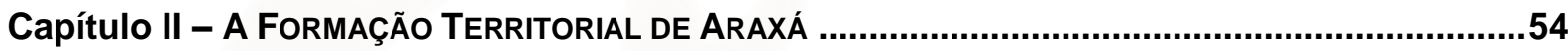

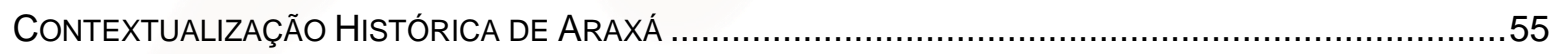

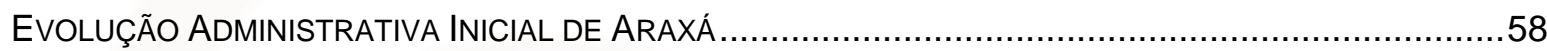

Capítulo III - TERRITORIALIdAdES SOBREPOStAS E RESISTÊnCIAS No CAMINHO ............................61

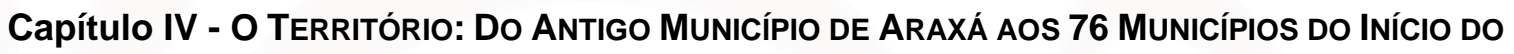

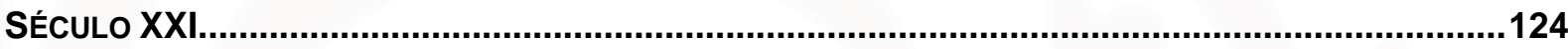

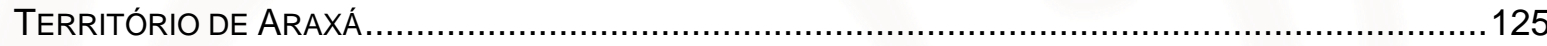

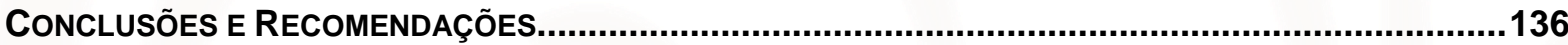

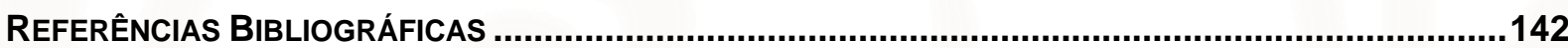




\section{ÍNDICE DE FIGURAS}

Figura 1 - Identificação Cartográfica da Área de Estudo ......................................24

Figura 2 - Encadeamento das Etapas de Realização da Pesquisa ..........................27

Figura 3 - O Espaço, a Região, o Campo e a Cidade - Conforme o entendimento de

Milton Santos

Figura 4 - Relações entre o Espaço e o Território Usado e entre as suas respectivas frações.

Figura 5 - Relações entre o Espaço e o Território Usado e Aplicação do Conceito de

Região.

Figura 9 - Zee en Land Reyse na Bresil, Rio de la Plata en de Zuyd Zee - 1706.....41

Figura 10 - - A Map of Terra Firma, Peru, Amazone-land, Brasil \& The North P. of La

Plata - 1729.

Figura 11 - Carte de la Terre Ferme, du Peru, du Bresil, et du Pays des Amazones

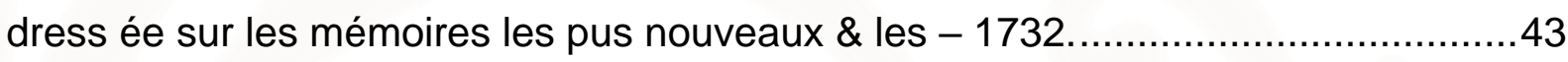

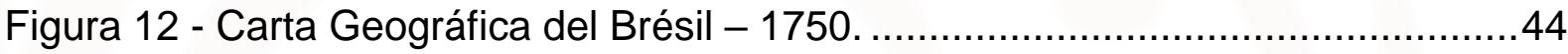

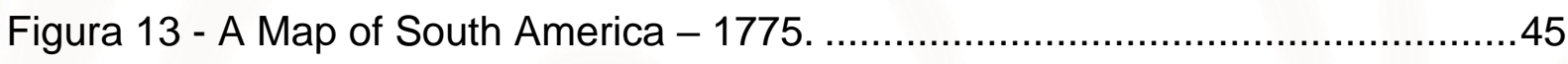

Figura 14 - General Map of South America From the Best Surveys - 1796..............46

Figura 15 - Mostrace neste mapa o Julgado das Cabeceiras do Rio das Velhas e parte da Capitania de Minas Geraes - 1796.

Figura 16 - Carta Corografica Plana da Provincia de Goyaz e dos Julgados de ARAXÁ e DESEMBOQUE da Provincia de Minas Gerais - 1826.

Figura 17 - Cartografia Histórica para aferir localização de Povos e Nações

Indígenas.

Figura 18 - Detalhe da Cartografia Histórica para aferir localização de Povos e

Nações Indígenas.

Figura 19 - Cartografia Histórica para aferir Estradas, Picadas e Caminhos.

Figura 20 - Detalhe da Cartografia Histórica para aferir Estradas, Picadas e

Caminhos.

Figura 6 - Destaque da Toponímia Sertão Kayapó na Cartografia Histórica.............56

Figura 7 - Localização do Sertão Kayapó na Cartografia Histórica.

Figura 8 - Município de Araxá. Municípios da Microrregião de Araxá 2015 - Minas

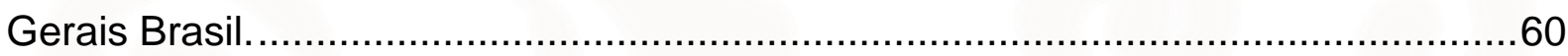

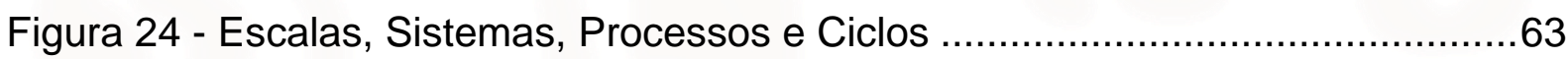

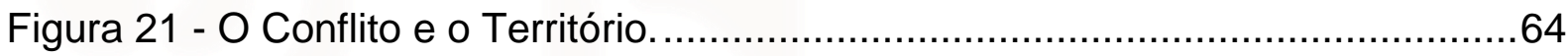

Figura 22 - Dinâmica Territorial da Colonização - Dinâmica da Resistência..............65

Figura 23 - Dinâmica Territorial da Colonização - Replicação da Dinâmica da

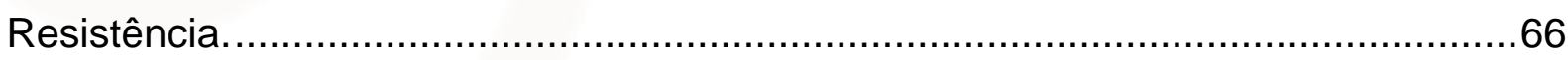

Figura 25 - Poder Central e Dinâmica Territorial no Contexto do Sistema Colonial. .70

BORGES, Roberta Maria Porfírio de Oliveira. 2018. 


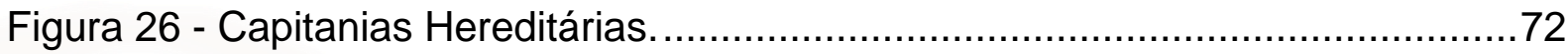

Figura 27 - Principais Nações Indígenas e Tratado de Tordesilhas. ........................74

Figura 28 - Expansão Jesuíta no século XVI.................................................... 81

Figura 29 - Visualização do significado de Sertão na Cartografia Histórica: Nova et

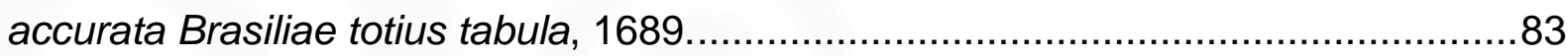

Figura 30 - Reflexão sobre a colonização do Território na Cartografia Histórica:

Amerique Meridionale 1669

Figura 31 - Ilustração da Configuração Espacial na Cartografia Histórica: Amerique Meridionale 1696

Figura 32 - Análise da Cartografia Histórica - Fraturas do Território em America Meridionalis in suas Praecipuas Partes Accuratè Divisa, ad Usum Serenissini Burgundiae Ducis 'L'Amerique Meridionale Divisée em Ses Principales Partes. Hlaillat. 1696.

Figura 33 - O Século das Bandeiras.

Figura 34 - Visualização da Configuração Territorial na Cartografia Histórica:

L'Amerique Meridionale 1700

Figura 35 - Da criação da Capitania de Minas Gerais à Capitação........................103

Figura 36 - Configuração Territorial pós-Capitação...........................................104

Figura 37 - Os Primeiros Ataques à Confederação Quilombola do Campo Grande 1741. 106

Figura 38 - Vários Ataques à Confederação Quilombola do Campo Grande - 1743.

Figura 39 - Grande Ataque - 1746 .........................................................108

Figura 40 - Análise da Cartografia Histórica - Sertão Cayapó I - Século XVII-XVIII.

Figura 41 - Análise da Cartografia Histórica - Sertão Cayapó - 1828......................111

Figura 42 - Detalhe do Arraial dos Bororós na Cartografia Histórica.

Figura 43 - Ambrósio II no mapa do Capitão Antônio Francisco França com os destaques feitos por MARTINS (2018). Detalhe da Cartografia Histórica: Mapa de Todo o Campo Grande 1760.

Figura 44 - Identificação da Primeira Povoação do Ambrósio feita por MARTINS (2018). Detalhe da Cartografia Histórica: Mapa de Todo o Campo Grande 1760...116 Figura 45 - Grande Guerra do Campo Grande e Guerra do Gentio Kayapó.

Figura 46 - Ataques ao Quilombo do Campo Grande.

Figura 47 - Gênese no Território de Conflito.

Figura 48 - Processo de desmembramento dos municípios oriundos do território do Município de Araxá - Minas Gerais - Brasil.....

Figura 49 - Processo de desmembramento dos municípios oriundos do território do Município de Araxá - Minas Gerais - Brasil - Linha do tempo da Área Aproximada dos municípios no respectivo ano de criação e área atual $\left(\mathrm{km}^{2}\right)$. 
Figura 50 - Distribuição do Território do Antigo Município de Araxá ao longo do tempo histórico.

\section{ÍNDICE DE QUADROS}

Quadro 1 - Principais Obras Cartográficas Coloniais e Imperiais Relacionadas ao Território de Araxá - 1706 a 1826.

Quadro 2 - Formação do território do Município de Araxá.

Quadro 3 - Área do Antigo Território de Araxá em relação à outras unidades territoriais nacionais e internacionais.

Quadro 4 - CÓDIGO DE ORIGEM TERRITORIAL DO MUNICÍPIO.

Quadro 5 - Método de Identificação da Origem Territorial, Classificação do Município e Atribuição do CÓDIGO DE ORIGEM TORRITORIAL DO MUNICÍPIO.

Quadro 6 - Território do Município de Araxá - Século XVIII ao Século XXI Municípios do Estado de Minas Gerais originários do território do município de Araxá de 1835.

\section{ÍNDICE DE GRÁFICOS}

Gráfico 1 - Área do Município de Araxá no decorrer do Tempo Histórico. 132

\section{ÍNDice DE TABELAS}

Tabela 1 - Tipos de Colonização 


\section{INTRODUÇÃO}

O reconhecimento e a construção da identidade de um povo, de uma nação começa no encontro com as raízes históricas e o entendimento da dinâmica formadora do território.

A formação de uma nação é o desenrolar de um processo multifacetado, de elementos heterogêneos e ciclos sincrônicos, diacrônicos e alternados, em uma dinâmica que ocorre no espaço, delineando o território em cada momento, deixando marca sobre marca, nas fronteiras, nos lugares, nas pessoas, de geração em geração, em territorialidades, na Formação Territorial.

Tendo como Objeto a Formação Territorial de Araxá - Minas Gerais - a Pesquisa tem como objetivo principal analisar o desenrolar deste processo no território da Região de Araxá. Um recurso metodológico-instrumental adotado para que o objetivo da pesquisa seja alcançado é a utilização da Cartografia Histórica, além dos dados históricos e da historiografia, para a construção da base de dados da pesquisa e para o desenvolvimento da Cartografia da Formação Territorial de Araxá.

A Formação Territorial não é fenômeno instantâneo, nem isolado no espaço.

A Formação Territorial de Araxá decorre do processo de colonização, de expansão territorial e de sobreposições de territorialidades, durante o Período Colonial, e ocorre sincronicamente com os demais processos mundiais, continentais, coloniais e locais da época.

No estudo da Formação Territorial de Araxá, são abordados os processos contextualizadores ou diretamente relacionados que são fundamentais para explicar a dinâmica local que desenvolve o processo objeto da pesquisa.

São contemplados aqui alguns aspectos e questões de períodos relevantes deste processo de Formação Territorial, que envolve importante território brasileiro, visando a melhor compreensão e representação cartográfica possível. 
Os aspectos tratados não foram escolhidos por serem mais importantes em relação a outros, e tão pouco foram esgotados nesta pesquisa, mas foram os possíveis de serem tratados da melhor forma possível neste momento.

Questões como a Guerra do Quilombo do Campo Grande e os Kayapós do Sul são abordadas na Cartografia como aspectos relevantes e determinantes na formação territorial de Araxá, no entanto, trata-se da superfície destas questões, sem contemplar nem mergulhos rasos em uma realidade ainda sombreada da história. Estas são questões tão densas e complexas que demandam pesquisas com foco específico, possibilitando assim que haja o devido aprofundamento para serem abordados em sua totalidade, o que fugiria do foco principal desta pesquisa.

A análise da Cartografia Histórica permite a utilização dos dados provenientes destes documentos na construção da Cartografia da Formação Territorial de Araxá aqui desenvolvida. A Cartografia Histórica é fonte documental norteadora de partes importantes da pesquisa.

A realização da reconstrução da História Territorial é baseada na evolução da unidade administrativa: Município, que engloba Campo e Cidade em unidade Administrativa Oficial. Os núcleos urbanos são a principal unidade territorial de análise da expansão colonial na Dinâmica da Formação Territorial em Territorialidades Sobrepostas e Resistências no Caminho.

O produto principal da pesquisa é a Cartografia da Formação Territorial de Araxá, realizada em documentos articulados, mas independentes, sendo, portanto, cada um capaz de isoladamente prestar o entendimento as informações nele tratadas.

A dissertação está estruturada da seguinte forma: No Capítulo I está o detalhamento da forma como a pesquisa foi desenvolvida, o método utilizado, a sequência metodológica assim como a fundamentação teórica e os principais conceitos utilizados; O Capítulo II traz a delimitação do tema e uma breve apresentação do espaço de investigação; Em seguida, o Capítulo III, trata da análise da Cartografia Histórica da Região de Araxá; Com o título Territorialidades Sobrepostas e Resistências no Caminho, o Capítulo IV apresenta os ciclos, processos e dinâmicas envolvidos na Formação Territorial de Araxá com a representação cartográfica do território em diversos momentos ao longo do tempo histórico com as 
configurações territoriais e espacialização dos eventos que levaram à gênese de Araxá no território de conflito; O Capítulo V começa com a criação do Município de Araxá, e traz o histórico e a representação cartográfica de todo o processo de divisão do Território do Antigo Município de Araxá até a atualidade; Finalizando, o Capítulo VI reúne as principais conclusões e recomendações. 
CARTOGRAFIA DA FORMAÇÃO TERRITORIAL DE ARAXÁ - MINAS GERAIS - DO SERTÃO KAYAPÓ AO TRIÂNGULO

\section{Capítulo I - Procedimentos Metodológicos e} FUNDAMENTAÇÃO TEÓRICA

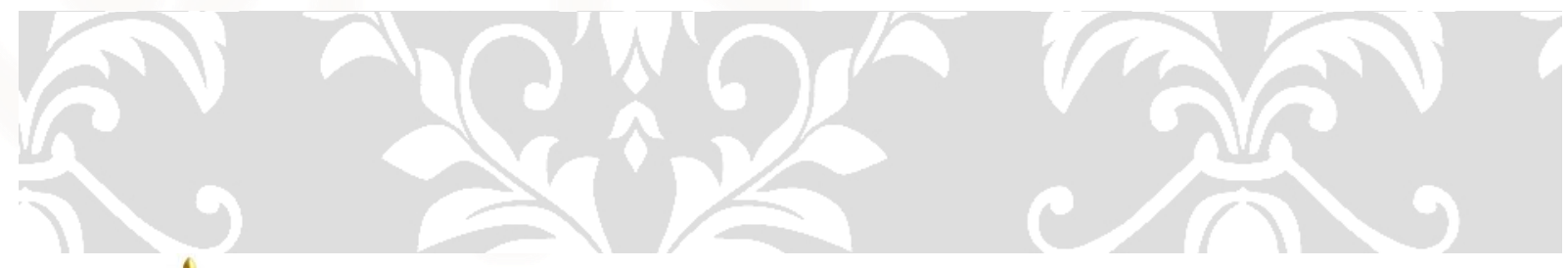




\section{Procedimentos Metodológicos}

A apresentação da pesquisa ocorre de acordo com o processo histórico da Formação territorial de Araxá no espaço, seguindo a linha do tempo, apesar de algumas digressões. Já o desenvolvimento da pesquisa não foi assim. A pesquisa fez um caminho distinto:

Começou no período contemporâneo, tomando o território de Araxá atual como referência. A partir da concretude do presente, procurou a configuração anterior e anterior sucessivamente buscando a gênese do núcleo urbano associado ao território pertencente a este, no decorrer das unidades administrativas vigentes.

Visto que o núcleo urbano nasce pertencendo a um território de outro núcleo urbano, no caso de Araxá, na época, o Julgado das Cabeceiras do Rio das Velhas com sede no núcleo urbano chamado Desemboque, buscou-se esta configuração territorial e a anterior da mesma, e assim, o contexto da formação tornou-se relevante para a compreensão do objeto.

Então, descortinou-se a necessidade de entender o processo de colonização, em uma escala mais ampla, não só do sudeste ou das Minas Gerais, mas dos Ciclos de expansão das fronteiras do Brasil e da ocupação de diferentes territórios "além Tordesilhas", que fizeram o território de Araxá - considerando a configuração territorial do "Antigo Município de Araxá" (BORGES 2015), que foi, em uma perspectiva de política mundial do início da expansão europeia, dividido quase que ao meio pelo Tratado de Tordesilhas - uma região de passagem estratégica, ligando interesses da metrópole ao litoral e ao interior.

Neste momento, buscou-se a Cartografia Histórica Colonial e Imperial para fornecer informações espaciais do território precedentes ao surgimento do núcleo urbano em si.

Em verdade a dinâmica desta pesquisa desenrolou-se como a montagem de um quebra-cabeças composto de muitas e diferentes peças, espalhadas, empoeiradas ou até esquecidas e perdidas em inúmeros lugares, no tempo e no espaço. Nem todas as peças foram encontradas, também várias das encontradas não se encaixaram... ainda. Mas um delineado já pode ser apreciado. Neste percurso, se descobriu como

BORGES, Roberta Maria Porfírio de Oliveira. 2018. 
fazer o que tinha que ser feito, buscando, conhecer para então compreender e fazer saber.

Por isso, a metodologia foi completamente subordinada ao estudo do objeto, ou seja, a metodologia adaptou-se, ajustou-se e reinventou-se para atender ao seu propósito de fazer o conhecimento do objeto acontecer. Não se trata de uma "corda bamba" ou de "laços-frouxos", mas de liberdade para adotar o ou os caminhos, no momento, mais adequados ou mais fascinantes para atingir o objetivo com o melhor resultado possível. É escolher abrir uma nova porta quando uma janela prédeterminada se fecha, é vencer os obstáculos que bloqueiam o caminho e seguir em frente.

O deslanchar da pesquisa só se deu, de fato, quando o que "precisava ser apresentado" (no sentido do rigor de nomear procedimentos e pró-formas), os títulos, as linhas divisórias e conceituais foram deixadas de lado em prol do que "se desejava conhecer", no caso o objeto da pesquisa. Então, a busca por conhecer este objeto tornou-se, novamente, apaixonante, uma encantadora e fascinante aventura de exploração, descobrimento e insights.

Esta forma de 'busca por conhecer' foi fundamental para realmente compreender, representar, cartografar, o que leva a fixar, analisar, apropriar. Assim, o pró-forma tornou-se claro e natural, possível de ser feito conscientemente e não mecanicamente ou apenas tecnicamente. Foi como sair de um "modo Chaplin" e terminar em um “modo Darcy", em alusão à prática de aprendizagem preconizada por este. Para a presente pesquisadora, o verdadeiro ganho foi conseguir, de certo modo, na perspectiva e sensação da mesma, aplicar na realização (de fato) desta pesquisa, o modo de desenvolvimento e aprendizado que tanto é falado e lido durante a formação de professores, na UnB, no campus que leva o nome do próprio Darcy Ribeiro.

Alguns critérios principais adotados para percorrer os caminhos escolhidos:

- Trazer informações da Cartografia Histórica na construção da Cartografia da Formação Territorial de Araxá aqui desenvolvida.

- Fazer da Cartografia Histórica fonte documental norteadora de partes importantes da pesquisa.

- Contar a Formação Territorial de Araxá como um enredo Cartografado.

BORGES, Roberta Maria Porfírio de Oliveira. 2018. 
- Definição da escala da Pesquisa: Multiescalaridade com variação de parâmetro no decorrer do tempo histórico.

- Considerar o recorte temporal e a multiescalaridade andando juntos nesta pesquisa, variando no decorrer do tempo histórico abordado.

- Definição da realização da reconstrução da História Territorial baseada na evolução da unidade administrativa: Município, que engloba Campo e Cidade em unidade Administrativa Oficial.

- Definição dos núcleos urbanos como uma das unidades de análise da expansão das fronteiras na Dinâmica da Formação Territorial em Territorialidades Sobrepostas e Resistências no Caminho.

Visando a viabilidade do estudo, no mestrado, a pesquisa não contempla todos os aspectos, questões e períodos relevantes ao processo de Formação Territorial de Araxá. São contemplados aqui alguns aspectos, questões e períodos deste processo de Formação Territorial, que envolve importante território brasileiro, visando a melhor compreensão e representação cartográfica possível.

Os aspectos tratados não foram escolhidos por serem mais importantes em relação a outros, e tão pouco foram esgotados nesta pesquisa, mas foram os possíveis de serem tratados da melhor forma possível neste momento.

Questões como a Guerra do Quilombo do Campo Grande e os Kayapós do Sul são abordadas na Cartografia como aspectos relevantes e determinantes na formação territorial de Araxá, no entanto, trata-se da superfície destas questões, sem contemplar nem mergulhos rasos em uma realidade ainda sombreada da história e que são questões tão densas e complexas que demandam pesquisas com este foco e que precisam de muito mais aprofundamento para serem abordados em sua totalidade, o que fugiria do foco principal desta pesquisa. 


\section{etapas da Pesquisa}

\section{Etapa 1 - História Territorial Oficial de Araxá - Evolução administrativa do Território de Araxá.}

Considerando o postulado por MORAES (2001) de que a Construção Política/Jurídica é um dos elementos da Formação Territorial, e, entendendo que a história administrativa de Araxá é uma materialização da Construção Política/Jurídica relacionada à Formação Territorial de Araxá, a primeira etapa da pesquisa buscou a história da Evolução administrativa do Território de Araxá.

A partir da Configuração atual do Território de Araxá, utilizando os dados do Instituto Brasileiro de Geografia e Estatística - IBGE (2015), que são as informações oficiais atuais, e os instrumentos legais - leis - de criação dos município, que são as informações jurídicas, foi realizada uma pesquisa da história administrativa de Araxá, visando a reconstrução da História Territorial de Araxá, retroagindo no tempo histórico de acordo com as mudanças e alterações das unidades administrativas próprias e/ou relacionadas à Araxá.

Cada unidade administrativa citada é pesquisada e, se confirmada a relação direta com o território de Araxá, é agregada à história territorial deste.

Esgotadas as unidades administrativas citadas, passou-se à pesquisa das unidades administrativas limítrofes, uma a uma, seguindo a contiguidade territorial das unidades historicamente associadas à Araxá, cada confirmação de história territorial relacionada à Araxá é agregada, conforme a metodologia própria para esta dinâmica (ver Capítulo V).

Desta forma, uma reconstituição da evolução administrativa é realizada, cartografada e analisada. Ao retroagir no tempo histórico, a precisão é satisfatória até a criação do município de Araxá, em 1835, cujo território identificado chamamos de Antigo Município de Araxá, ou simplesmente, o Antigo Araxá. 


\section{Etapa 2 - Espacialização da evolução administrativa do território do Antigo Município de Araxá}

Realização da representação cartográfica utilizando as ferramentas de Sistema de Informação Geográfica (SIG) da evolução administrativa do Antigo Município de Araxá.

\section{Etapa 3 - O referencial da Área de Estudo na Cartografia Histórica.}

Nesta etapa foi identificada a necessidade de definir Referências para identificação da Área de Estudo na Cartografia Histórica e em outras situações em que for necessária esta forma de localização.

Definição de Referências para identificação da Área de Estudo.

Assim, a definição de Referências para identificação geográfica da Área de Estudo se mostrou necessária para viabilizar etapas da pesquisa, como a Análise da Cartografia Histórica em 'Cartografia Histórica: Principais Referências Cartográficas Coloniais e Imperiais' - Capítulo III - onde há documentos cartográficos cuja produção precede a criação do município, do julgado e até mesmo a constituição do núcleo urbano de Araxá.

Reconhecendo a hidrografia como elemento mais adequado para este propósito, foram definidas as seguintes Referências Hidrográficas para identificação da Área de Estudo:

O Rio Grande e o Rio Paranaíba, ambos pertencentes à Bacia do Rio Paraná, que delimitam a área a Norte, a Sul e a Oeste. A leste da área de estudo, a Referência Hidrográfica é o Rio São Francisco e a sudeste da área de estudo, as Cabeceiras do Rio São Francisco. 


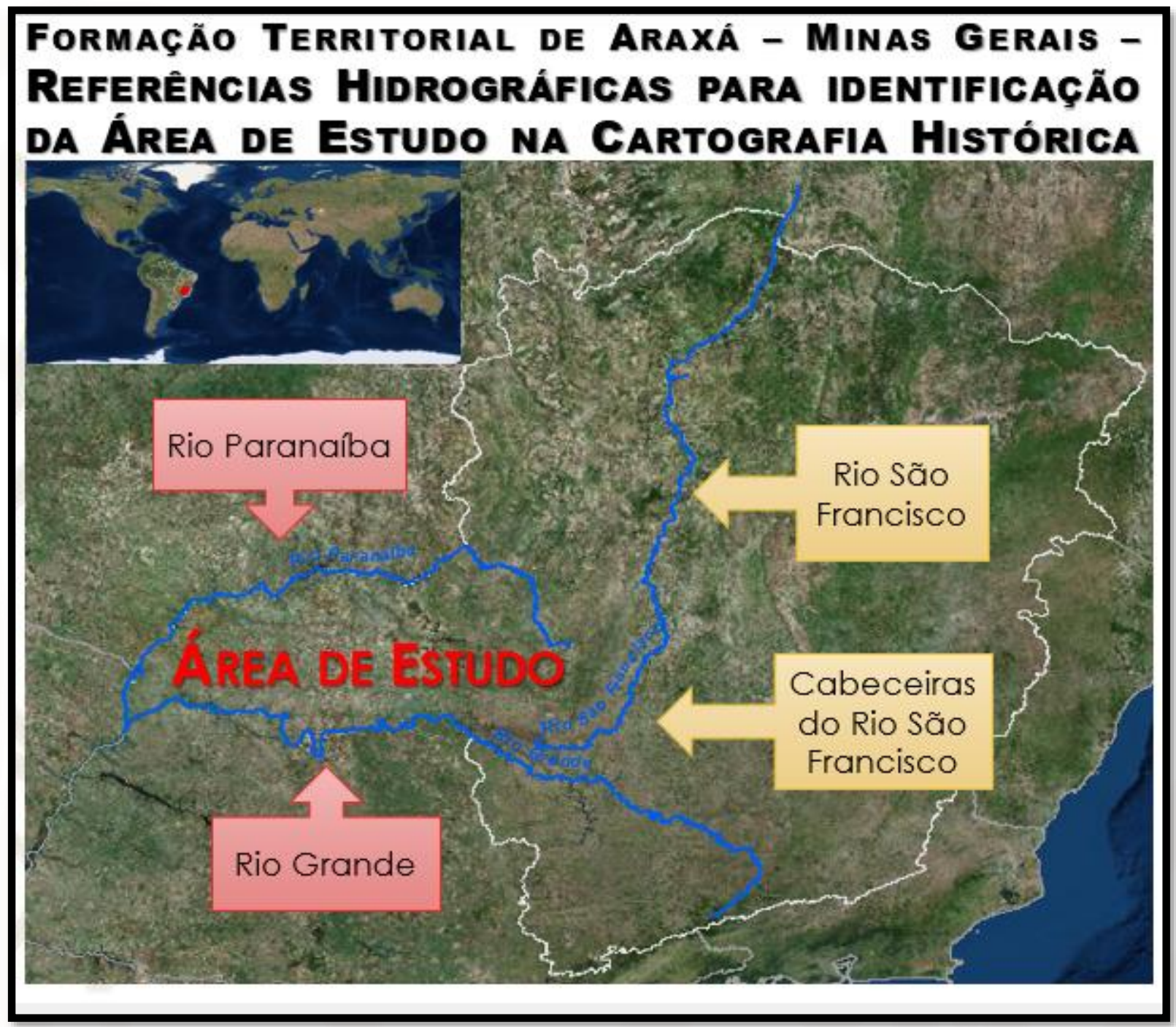

Figura 1 - Identificação Cartográfica da Área de Estudo

Da definição das Referências Hidrográficas para identificação da Área de Estudo, juntamente com a reconstrução da evolução administrativa de Araxá, realizada na etapa anterior, deriva a possibilidade de definição do território que corresponde ao conceito de Região no âmbito da Pesquisa: a Região de Araxá, que corresponde ao território do Antigo Araxá, compreendido na Área de Estudo.

Aferição da correlação da História territorial de Araxá com o contexto Histórico Regional, Nacional e Global.

- Contexto Histórico (Quadro do Contexto Histórico do Território de Araxá)

- Comarca do Rio das Mortes 


\section{Etapa 4 - Levantamento da Cartografia Histórica como referência e fonte de dados na pesquisa.}

Levantamento da Cartografia Histórica mais adequada para obteção de dados para a pesquisa. Foi considerada, principalmente a legibilidade dos dados. As Cartografias Históricas mais legíveis, dos períodos retratados e que forneciam dados sobre os elementos selecionados para serem cartográficamente representados da região a ser trabalhada, foram selecionadas, independente da nação procedente, do idioma em que foi produzida, do título ou do foco da publicação.

\section{Etapa 5 - Reconstrução do contexto histórico, político e geográfico}

Levantamento do contexto histórico da Formação Territorial de Araxá, buscando identificar a relação da evolução da divisão administrativa com o a realidade da unidade territorial em que o território estudado está inserido.

Acreditando que um conflito armado é o ápice de uma situação previamente instalada que se desenvolveu até então de forma conflituosa e que os efeitos de um conflito se propagam ao longo do tempo, nos conflitos relacionados a contextualização, como não são o foco da pesquisa, visando viabilizar uma contextualização mais ampla mas que ao mesmo tempo não concorra com o objetivo principal da pesquisa, são utilizados os dados das fontes que os oferecem da forma mais clara e sistematizada possível, sem preocupação de averiguação de grau de precisão ou discussão dos mesmos, visto que oferecem a referência temporal e espacial que a contextualização demanda.

A mesma lógica é adotada na abordagem dos aspectos legais e políticos da contextualização. Levantamento dos aspectos legais, jurídicos e políticos referentes às dinâmicas territoriais relacionadas, identificando os principais marcos legais.

\section{Etapa 6 - Elementos da Dinâmica da Formação Territorial de Araxá}

Foram definidos os seguintes elementos do processo de colonização para serem espacializados: 
- Ocupação pré-colonial;

- História político-administrativa precedente;

- Jesuítas

- Bandeiras / Entradas;

- Novos Núcleos urbanos no Ciclo do Ouro: de Ibituruna a Rio das Pedras;

- Caminhos / Estradas / Picadas

- Conflitos

- A Comarca do Rio das Mortes

Buscando uma visão integrada do Processo estudado com os elementos que o compõem, estes não terão uma abordagem isolada, o tratamento de cada elemento de colonização se dá durante a Cartografia da Formação Territorial de Araxá.

Dentre os conflitos especializados, os mais importantes, devido à sua relação e proximidade com o objeto da pesquisa, são a Grande Guerra do Quilombo do Campo Grande e a Guerra dos Kayapós do Sul, os quais serão referidos como Kayapós.

A partir de MARTINS (2008), é delineado o enredo da Grande Guerra do Quilombo do Campo Grande.

A espacialização da Guerra dos Kayapós do Sul é feita a partir do trabalho de Mori (2015).

\section{Etapa 7-Espacialização do Contexto Histórico da Formação de Araxá}

Realização de representações cartográficas utilizando as ferramentas de Sistema de Informação Geográfica (SIG) para:

Espacialização da evolução da divisão administrativa e no contexto continental.

Espacialização da Grande Guerra do Quilombo do Campo Grande, como expressão da interação da escala Global com a escala local, que contextualiza a gênese de Araxá. 
Identificação, projeção e análise das principais dinâmicas e conflitos ao longo do processo de formação territorial de Araxá.

\section{Formação Territorial de Araxá - Minas Gerais - Encadeamento das etapas de Realização da Pesquisa}

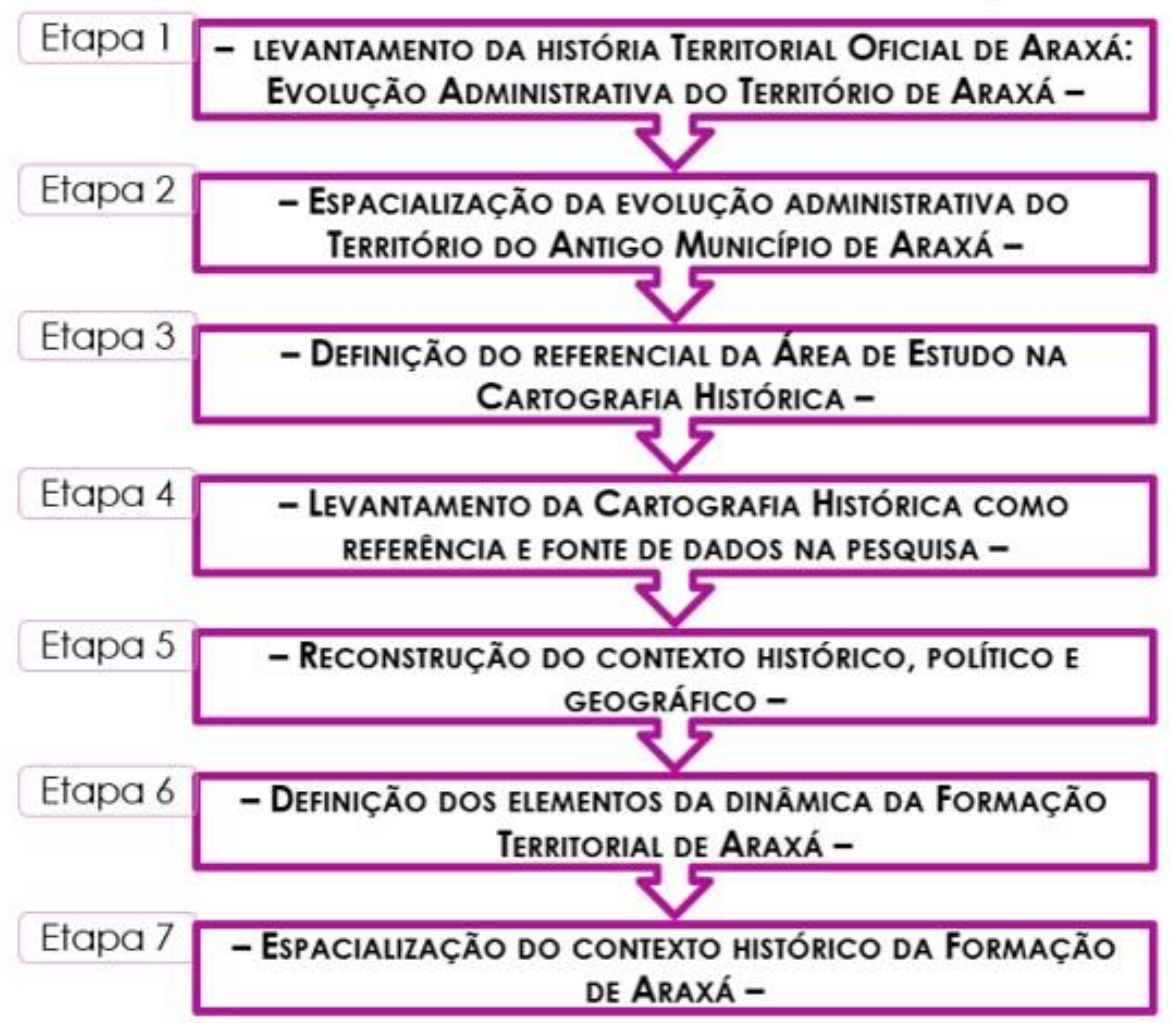

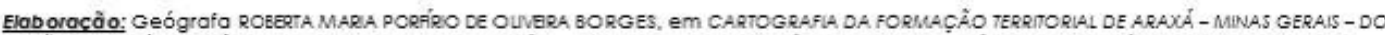
SERTÃO CAYAPÓ AO TRIÂNGULO MINEIRO E ALTO PARANAIGA - MERANCGAS HITORIOGRÁFICAS E BASES DA GÉNESE NO TERRTÓRIO DE CONFLTO, 2018.

Figura 2 - Encadeamento das Etapas de Realização da Pesquisa

\section{Fundamentação Teórica e Principais Conceitos}

Consideramos o entendimento de Santos (1996) de que o Espaço é um "conjunto indissociável de Sistemas de Objetos e Sistemas de Ações".

Os objetos e ações são unidos nos eventos, que são os vetores da metamorfose do espaço. O Evento é um portador de um acontecer histórico que torna o tempo concreto. (SANTOS 1996, p. 15) 
"O espaço seria um conjunto de objetos e de relações que se realizam sobre estes objetos; não entre estes especificamente, mas para as quais eles servem de intermediários. Os objetos ajudam a concretizar uma série de relações. O espaço é resultado da ação dos homens sobre o próprio espaço, intermediados pelos objetos, naturais e artificiais". (SANTOS 1988, p. 25)

Segundo Santos (1994), o Espaço Geográfico é sinônimo de "Território Usado", conceito fundamental para a compreensão do mundo, é uma mediação entre o mundo e a sociedade nacional e local. (SANTOS 1994)

"O espaço é o resultado da soma e da síntese, sempre refeita, da paisagem com a sociedade através da espacialidade. A paisagem tem permanência e a espacialidade é um momento. A paisagem é coisa, a espacialização é funcional e ó espaço é estrutural. A paisagem é coisa relativamente permanente, enquanto a espacialização é mutável, circunstancial, produto de uma mudança estrutural ou funcional. A paisagem precede a história que será escrita sobre ela ou se modifica para acolher uma nova atualidade, uma inovação. A espacialização é sempre o presente, um presente fugindo, enquanto a paisagem é sempre o passado, ainda que recente". (SANTOS 1988, p. 26, grifo nosso)

O Espaço é Movimento, é ação que define a forma-conteúdo do Território Usado (SANTOS 1996), portanto o Território Usado é produto do Espaço e é dinâmico pela natureza do que o forma. 


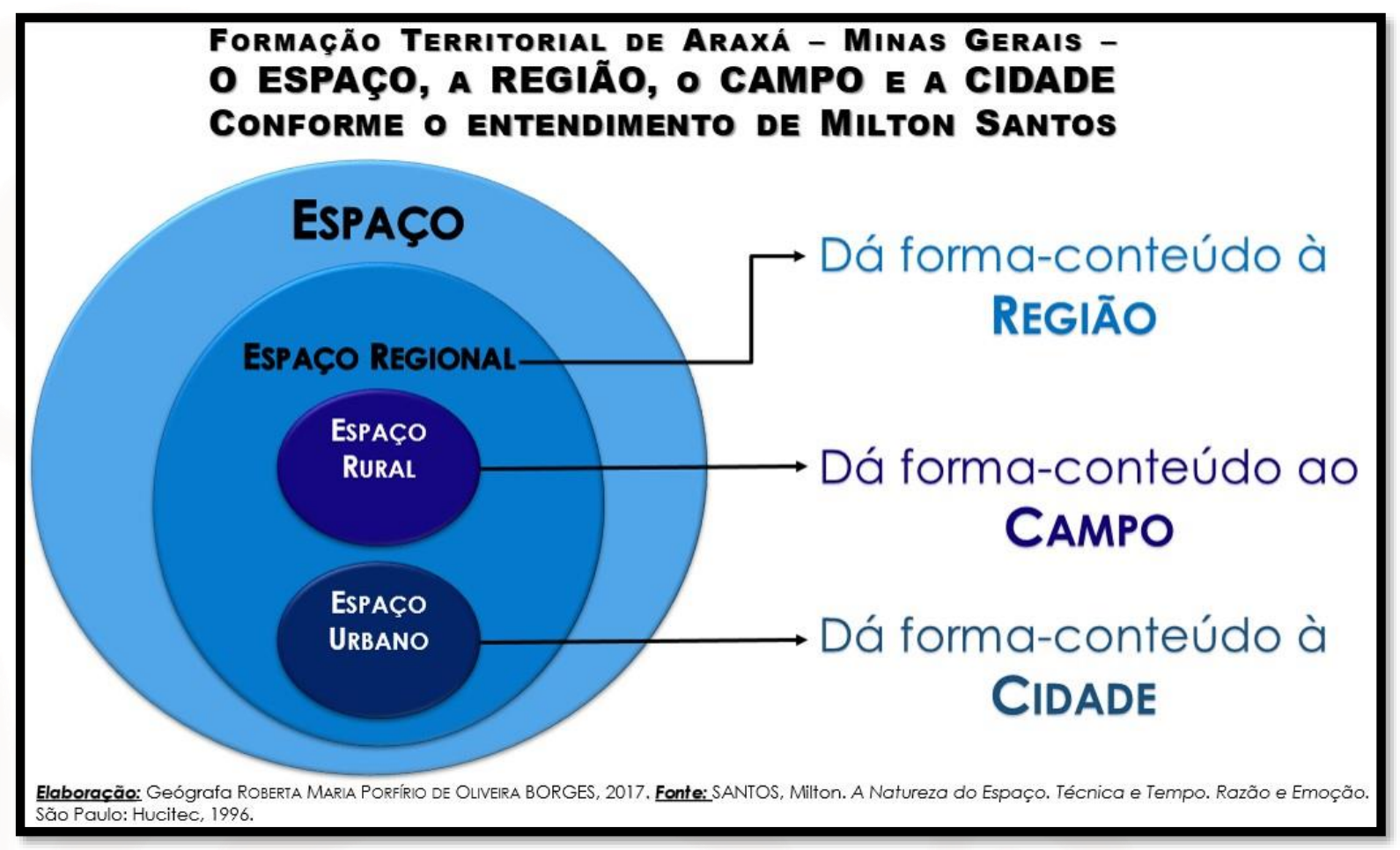

Figura 3 - O Espaço, a Região, o Campo e a Cidade - Conforme o entendimento de Milton Santos

Segundo Santos (1988) a Totalidade é uma unidade da pluralidade ou diversidade, que é "a essência nova ou renovada, cuja vocação consiste em deixar de ser potência para tornar-se ato". Esta essência que é conteúdo, é a sociedade em andamento, em evolução, em movimento, como conteúdo corporificado, ou seja, já transformado em existência, "é a sociedade já embutida nas formas geográficas, a sociedade transformada em espaço. A totalidade é "um movimento permanente, e por esse processo infinito a sociedade e o espaço evoluem contraditoriamente" (SANTOS 1988, p. 5-6; SANTOS 1988, p. 43-46, grifo nosso)

Portanto, se o Espaço define a forma-conteúdo do Território Usado, a relação entre o Espaço e o Território Usado é de definição. Sendo o Espaço um conjunto indissociável de Sistemas de Objetos e Sistemas de Ações, então um conjunto de sistemas define a forma-conteúdo do território. Como sistema é movimento, e movimento é uma dinâmica, então é uma dinâmica que define o Território Usado. Podemos dizer que a Dinâmica Territorial (TerritorializaçãoDesterritorialização-Reterritorialização) é dada pelo Espaço e o Território Usado é definido pelo Espaço. 
A produção e reprodução do Espaço ocorre com o processo permanente de Totalização, que é um processo infinito de movimento permanente de unificação e de fragmentação e individuação da totalidade, é uma dinâmica permanente de dissolução e recriação do sentido na sucessão interminável de formas-conteúdo. (SANTOS 1996, p. 14, grifo nosso)

A cada cisão da totalidade os lugares ganham um novo conteúdo, um novo significado, um novo sentido. "É assim que os lugares se criam, e se recriam e renovam, a cada movimento da sociedade". (SANTOS 1996, p. 14)

Nesta pesquisa entendemos o Território como uma dimensão de natureza concreta e dinâmica, cujo posicionamento relacional na multiescalaridade do espaço se modifica e se desloca no decorrer do tempo histórico, tanto por sua relação com as demais escalas, quanto pela singularidade dos seus movimentos e transformações internas e inerentes ao seu papel no conjunto quanto à sua própria essência, genuína, preservada, transformada ou adquirida conforme seu posicionamento real na dinâmica territorial.

Santos (1994) ressalta que o Território é formado de lugares. O território, como base e fundamento do Estado-Nação, que o molda e define os lugares, ou seja, a noção de território "estatizado". (SANTOS 1994, grifo nosso)

O Lugar é o espaço da existência e da coexistência, é palpável, é o lugar que recebe os impactos do mundo. Mundo e lugar são indissociáveis, e o lugar é controlado remotamente pelo mundo. (SANTOS 1994, grifo nosso)

O lugar, como coexistência no espaço geográfico e como espaço do acontecer solidário, define usos e gera valores de diversas naturezas, como culturais, sociais e financeiros. As normas locais e regionais são fruto da construção de uma base de vida comum derivada da união horizontal de lugares. (SANTOS 1994) 


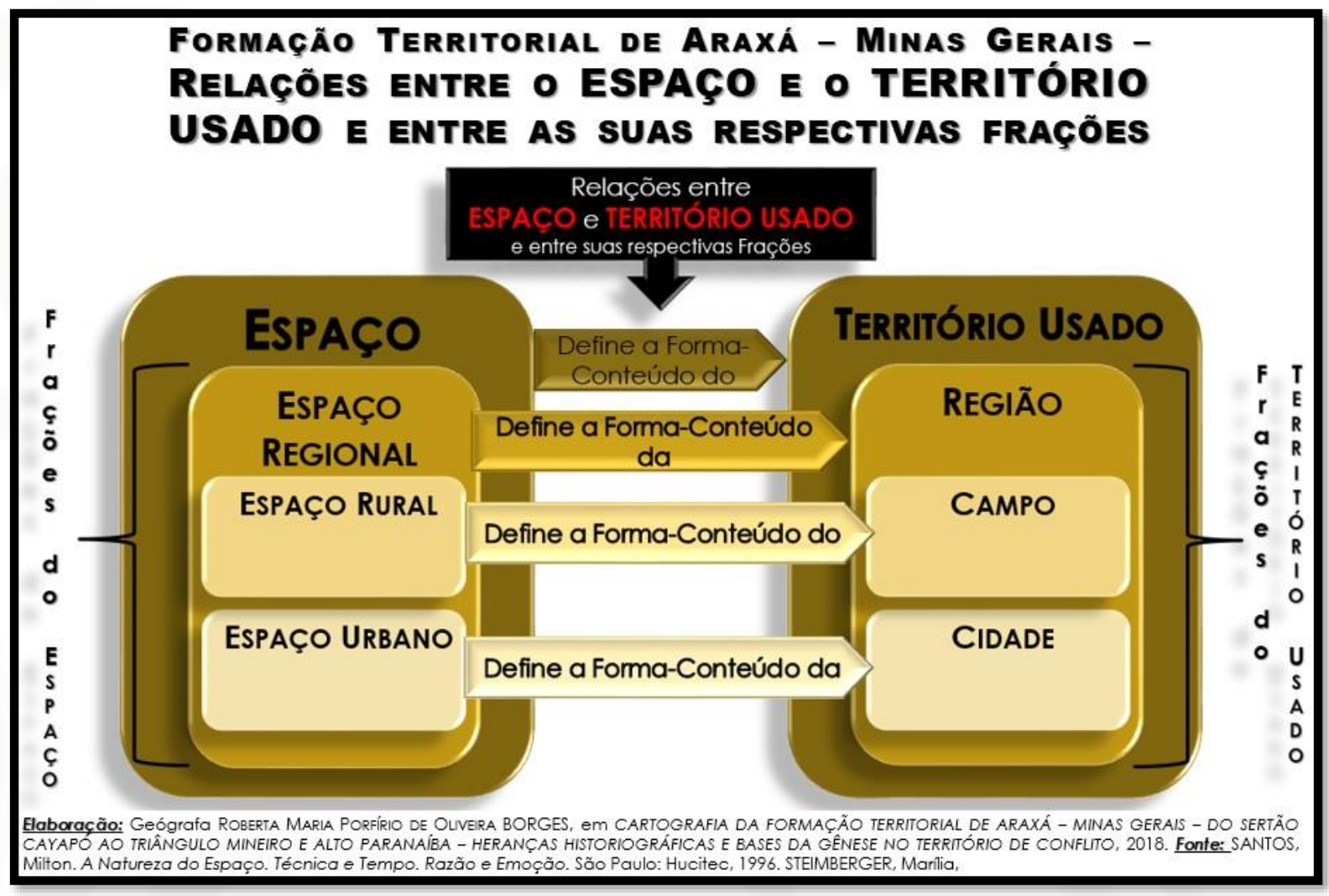

Figura 4 - Relações entre o Espaço e o Território Usado e entre as suas respectivas frações.

Das relações entre o Espaço e o Território Usado decorrem o Processo de Formação Territorial.

Adotamos o entendimento de Antônio Carlos Robert de Moraes (2001) de Formação Territorial, segundo Moraes, a formação territorial envolve três dimensões: Pleito Ideológico; Legalização Jurídica/Legalização Política e Conquista Militar, não necessariamente nesta ordem, visto que a sequência pode ocorrer de diferentes formas em cada caso. (MORAES 2001, p. 105-106, grifo nosso)

Entendemos que o ciclo das três dimensões da Formação Territorial se manifesta no processo da seguinte forma:

1 - Construção bélica/militar - efetivação da conquista militar:

\section{Conflitos armados.}

2 - Construção jurídica - legalização jurídica/ legalização política:

BORGES, Roberta Maria Porfírio de Oliveira. 2018. 


\section{Evolução administrativa.}

3 - Construção ideológica - pleito ideológico:

Colonização do território.

Formação Territorial é Processo, processo é movimento ao longo do tempo, movimento é dinâmica.

A dinâmica das dimensões da Formação Territorial deixa marcas no Território Usado em todas as suas frações (Região, Campo, Cidade).

Considerando que a Formação Territorial é um processo que envolve diversos sistemas e dinâmicas ao longo do tempo, e que estes sistemas e dinâmicas marcam o território, podemos dizer que a dinâmica territorial acontece em um território que carrega as marcas de um processo em largo espectro de formas, intensidades e sobreposições.

Portanto, mesmo que a unidade territorial mude, ou seja extinta, passando o território a fazer parte de outra unidade territorial, a formação territorial da unidade territorial precedente sempre fará parte da história da formação territorial da nova unidade, mesmo que todas as marcas territoriais do passado sejam apagadas, 0 contexto de criação sempre fará parte do processo de gênese da nova unidade territorial. Nessa perspectiva, consideramos que o processo de formação territorial engloba as marcas dos processos pretéritos tanto na porção de terra em que ocorre, como nos processos que regem a transformação que está sendo operada.

Entendendo o caráter dinâmico e contínuo do Espaço e do Território, resta inadequado falar de Formação Territorial como algo que acontece tendo início, meio e fim, porém, podemos periodizar e/ou identificar ciclos do processo.

Considerando que as dimensões da Formação Territorial podem não ocorrer de forma sincronizada, os períodos, quanto espaço de tempo, se mostram rígidos para contemplar as dimensões da Formação Territorial.

Nesta pesquisa, os períodos são utilizados, por exemplo, na representação cartográfica, mas sem a rigidez que poderia diminuir a eficiência do documento 
produzido, portanto, informações de outros períodos que sejam importantes ou que sejam de eventos em curso no período que está sendo representado, tendo iniciado em período anterior, compõem o Documento Cartográfico, independentemente da periodização.

Os ciclos permitem um tratamento mais independente de cada movimento e a sua integração à heterogeneidade do processo. Os ciclos permitem a visão da especificidade na complexidade do lugar, do espaço ou do território.

Os ciclos também apresentam limitações, visto que os ciclos não ocorrem isolados na totalidade dinâmica do espaço, e, os ciclos que compõe o processo de Formação Territorial, em uma visão sincrônica de um momento, geralmente estão diferentes estágios, portanto, múltiplos ciclos ocorrem de forma simultânea, mas podem sincronizar-se ou não.

Os ciclos dão suporte à Multiescalaridade aplicada nesta pesquisa, em que, à medida que a complexidade da Formação Territorial adensa a rede com a multiplicação de núcleos urbanos ao longo do tempo histórico, a escala vai aumentando. É importante frisar que a multiescalaridade ocorre, mesmo com a variação das escalas ao longo do tempo histórico, mantendo em todas as escalas Araxá no foco. 


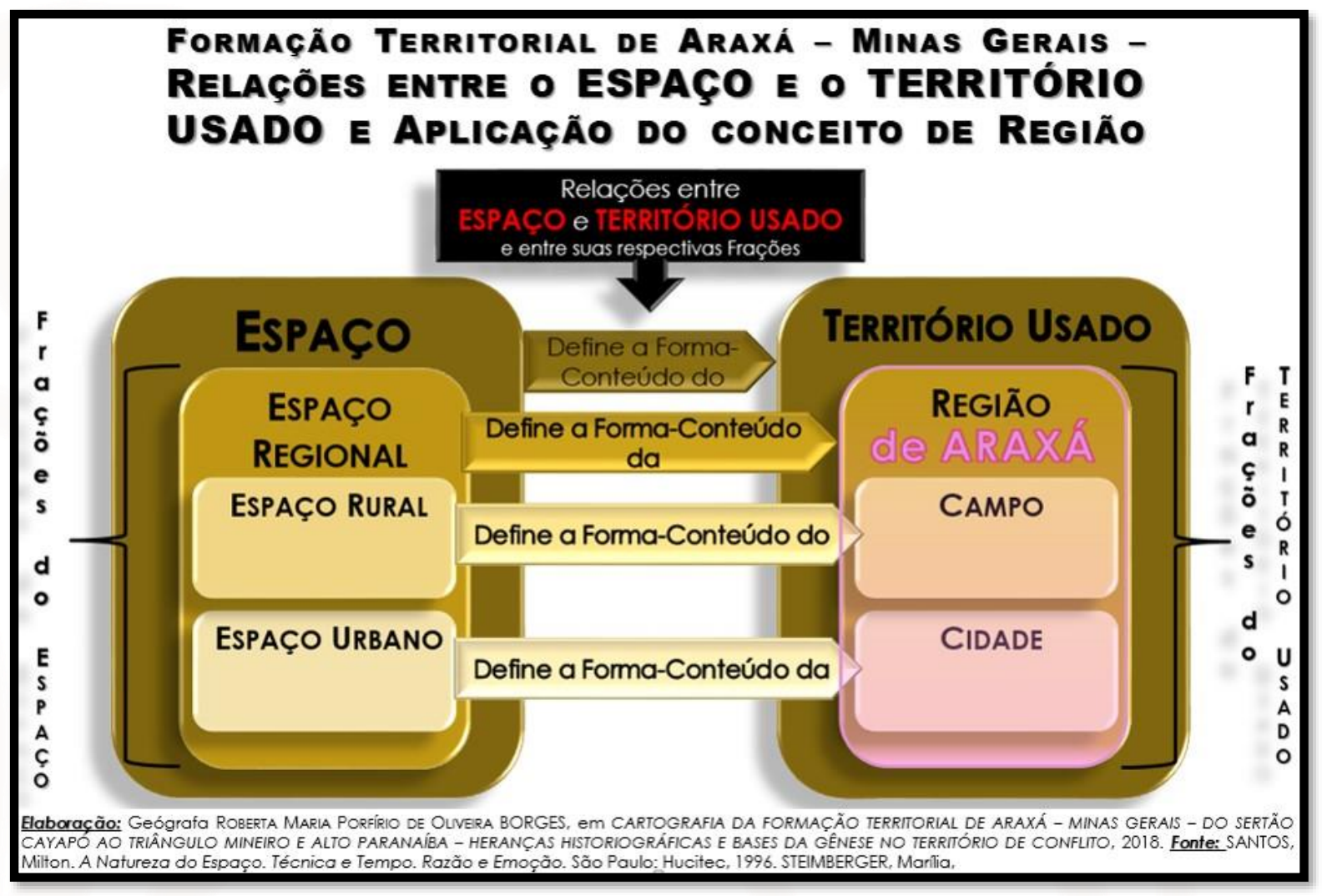

Figura 5 - Relações entre o Espaço e o Território Usado e Aplicação do Conceito de Região.

Todas as projeções históricas e geográficas, diacrônicas e sincrônicas, recaem sobre a Região de Araxá. Ou seja, este recorte é utilizado para a referência espacial desde as análises de contextos pretéritos à criação de unidades políticas colonizadoras na região até a atualidade, quando serão tratadas as criações dos mais novos municípios da região.

Nesta pesquisa, a Formação Territorial de Araxá é um processo cujo estudo e representação ocorre da de forma diacrônica e sincrônica.

Araxá é estudado de forma diacrônica e nesta Diacronia a Sincronia do contexto é considerada em todo o percurso e na Cartografia da Formação Territorial de Araxá a representação da sincronia dos ciclos, sistemas e processos de determinados momentos é especializada, como uma "fatia" do momento histórico cartografada. 
"Diacronia e sincronia, vistas através do espaço geográfico são, exclusivamente, duas faces de um mesmo fenómeno, ou, ainda melhor, duas formas de perceber um movimento unitário". (SANTOS 1996, p. 178)

Santos afirma que a "geograficidade se impõe como condição histórica, na medida em que nada considerado essencial hoje se faz no mundo que não seja a partir do conhecimento do que é o Território". (SANTOS 1999)

Fato é que o real conhecimento do território só é possível com o entendimento do seu Processo de Formação Territorial, e que, o entendimento deste Processo só é possível com o conhecimento de seu contexto em toda a sua complexidade e da dinâmica da totalidade espacial em que tal Processo de Formação Territorial está inserido.

Segundo Cordeiro, a historiografia se encaixaria no conhecimento produzido a respeito dos acontecimentos passados, que são enquadrados na dimensão do relato dos acontecimentos passados (Historie). (CORDEIRO 2015, 1-2)

"A Historiografia, palavra de origem grega (ıторіоүрачі́a), pode ser traduzida como grafia (escrita, -үрафía) da história (ıтторía), "em sua concepção mais corrente, remete ao produto final do ofício do historiador, podendo ainda ser entendida como conjunto de obras históricas produzidas por historiadores ao longo do tempo. Porém, deste conceito aparentemente simples emergem muitas questões que se relacionam diretamente com a polissemia da palavra história". (CORDEIRO 2015, p. 1)

Seguindo o entendimento de Cordeiro (2015), podemos dizer esta pesquisa se baseia não só em documentos históricos, mas também em fontes historiográficas, nas heranças historiográficas do processo de Formação Territorial de Araxá.

Nesta pesquisa, a Cartografia Histórica é documento Histórico, é fonte de dados, informações e análises. 
Ao articular documentos cartográficos de diferentes épocas, contemplando a contextualização em escala global/impérios/coroas, colonial/nacional, capitanial/estadual, regional e local, busca-se uma compreensão maior das forças atuantes no período em que os fatos formadores das dinâmicas ocorreram, e desta forma, possibilitar a reflexão sobre as condições de criação dos documentos.

Consideramos o entendimento de Santos (1996) de que as Redes "são um veículo de um movimento dialético que, de uma parte, ao Mundo opõe o território e o lugar; e, de outra parte, confronta o lugar ao território tomado como um todo". (SANTOS 1996, p. 182)

Segundo Santos (1994), "as redes constituem uma parte do espaço, constituem o espaço de alguns", "mas os lugares que formam as redes, ou seja, o espaço de alguns, são os mesmos que formam o espaço de todos".

Santos ainda ressalta que as redes "são produzidas, comandadas, disciplinadas e normatizadas pelo Mundo, que impõe uma racionalidade às redes". (SANTOS 1994, grifo nosso). As redes se aplicam no sistema colonial, de forma própria:

"No primeiro momento, as redes existentes serviam a uma pequena vida de relações. O espectro do consumo era limitado. Exceto para uns poucos indivíduos, as sociedades locais tinham suas necessidades localmente satisfeitas. Os itens trocados eram pouco numerosos $\mathrm{e}$ as trocas pouco frequentes. $\mathrm{A}$ competitividade entre grupos territoriais era praticamente inexistente, em períodos normais. O tempo era vivido como um tempo lento. No segundo momento, o consumo se amplia, mas o faz moderadamente. As modernidades se localizam de modo discreto. O progresso técnico tem utilização limitada. O comércio é direta ou indiretamente controlado pelo Estado. Se a respectiva formação socioeconômica se estende além dos oceanos, essa expansão é limitada a alguns fins. O "mercado mundial" é a soma dos mercados coloniais. Graças à colonização, o comércio internacional é "fechado". As redes buscam mundializar-se, e 
fisicamente o fazem, mas seu funcionamento é limitado. As fronteiras são um fato económico, financeiro, fiscal, diplomático, militar, além de político". (SANTOS 1996, p. 176-179, grifo nosso)

Verticalidades, formadas por pontos descontínuos, distantes entre si, descontinuidade territorial, ligados por formas e processos sociais, através das quais, juntamente com as horizontalidades (contiguidade territorial de lugares), funciona 0 território. (SANTOS 1994)

Santos (1996) ressalta que "as redes seriam incompreensíveis se apenas as enxergássemos a partir de suas manifestações locais ou regionais. Mas estas são também indispensáveis para entender como trabalham as redes à escala do mundo".

Através das redes podemos reconhecer três totalidades que são empiricizadas por intermédio das redes: a primeira totalidade é o mundo, a segunda totalidade é o território, de um país e um Estado resultante de um contrato e limitada por fronteiras e a terceira totalidade é o lugar "onde fragmentos da rede ganham uma dimensão única e socialmente concreta, graças a ocorrência, na contiguidade, de fenómenos sociais agregados, baseados num acontecer solidário, que é fruto da diversidade e num acontecer repetitivo, que não exclui a surpresa". (SANTOS 1996, p. 182)

Dentre os produtos desta pesquisa estão os Mapas Temáticos da Cartografia da Formação Territorial de Araxá. Consideramos a definição Mapas Temáticos no entendimento de Anjos (1996):

"Mapas temáticos são documentos cartográficos especializados, explicativos e analíticos cujo objetivo é fornecer, com auxílio de uma linguagem gráfica, uma representação de dados do espaço geográfico possíveis de mensuração, assim como de suas correlações". (ANJOS 1996 apud ANJOS 2000, grifo nosso)

Ainda sobre a importância da cartografia Anjos (2000) ressalta que: 
"Os mapas, portanto, podem revelar as construções sociais no território e, justamente por esse potencial, apontar os conflitos e as harmonias territoriais". (ANJOS 2000, p. 39)

\section{Principais Referências Cartográficas Coloniais e}

\section{IMPERIAIS}

Entre as principais referências cartográficas coloniais e imperiais que retratam a região, foram selecionadas, dentre as encontradas, oito para uma análise da representação da Região de Araxá na Cartografia Histórica até o período que precede a criação do Antigo Município de Araxá.

A qualificação de "principais" foi utilizada por serem essas obras as de maior destaque e recorrência nas pesquisas por Cartografias Históricas relacionadas à pesquisa, aparecendo expressivamente mais vezes nos resultados do que as outras Cartografias Históricas utilizadas na pesquisa.

Todas as informações relacionadas a: Ano, Local, Idioma e Autor, dispostas no quadro que lista as Obras escolhidas para essa análise (Quadro 1) são de acordo com os dados catalográficos da Biblioteca Nacional, conforme a fonte indicada no próprio quadro. Para viabilizar a realização da pesquisa e por entender que a Biblioteca Nacional do Brasil é um órgão oficial para catalogação de Obras Historiográficas, não houve uma investigação da adequação e precisão destas informações catalográficas, houve a utilização das mesmas conforme foram disponibilizadas.

As referências cartográficas analisadas são cartas europeias e americanas, catalogadas como obras nos seguintes idiomas: Espanhol, Francês, Italiano, Inglês e Português, no entanto, todas possuem termos nos Idiomas Indígenas regionais. As obras cartográficas foram selecionadas e dispostas em ordem cronológica (Quadro 1 e Obras № I a VIII, respectivamente: Figuras 9 a 16) para análise em relação à historiografia da formação territorial e administrativa regional (Formação do Território do Município de Araxá - 1608 a 1835 - Quadro 2). 
Os primeiros registros cartográficos da região traziam a hidrografia da Bacia do Rio Paraná, da qual são afluentes os dois rios, Rio Grande e Rio Paranaíba, que delimitam o território do Triângulo Mineiro, e alguns aspectos de relevo, no entanto, a representação limitava-se ao Rio Paraná, ou apenas a presença do encontro de dois afluentes formando o Rio Paraná. Em 1775 (Obra nō V - Figura 13), época de crescimento da importância da região, aparecem especificados além do Rio Paranaíba e do Rio Grande, também o Rio das Velhas, onde (conforme demonstrado no Quadro 2) à margem esquerda desenvolveu-se o Arraial de Nossa Senhora do Desterro das Cabeceiras do Rio das Velhas (Desemboque) e à margem direita desenvolveu-se o Arraial de São Domingos do Araxá (Araxá).

A evolução da representação cartográfica dessa região acompanha o histórico da evolução administrativa. As cartas luso-brasileiras aqui apresentadas foram realizadas com objetivo oficial de conhecimento para auxiliar a administração da região, como demonstra o título da carta Mostrace neste mapa o Julgado das Cabeceiras do Rio das velhas e parte da Capitania de Minas Geraes com a devisa de ambas as Capitanias dado pelo Capitam (Obra no VII - Figura 15) que explicita a divisa das Capitanias e a autoria da divisa: "dada pelo Capitão". 


\begin{tabular}{|c|c|c|c|c|c|}
\hline \multicolumn{6}{|c|}{$\begin{array}{l}\text { PRINCIPAIS OBRAS CARTOGRÁFICAS COLONIAIS E IMPERIAIS } \\
\text { RELACIONADAS AO TERRITÓRIO DE ARAXÁ - } 1706 \text { A } 1826\end{array}$} \\
\hline $\begin{array}{l}\text { ANO } \\
\text { № DA OBRA } \\
\text { E } \\
\text { REFERÊNCI } \\
\text { A }\end{array}$ & TíTULO ORIGINAL & TítULO TRADUZIDO & $\begin{array}{l}\text { LOCAL E } \\
\text { IDIOMA }\end{array}$ & $\begin{array}{l}\text { PRINCIPAIS } \\
\text { INFORMAÇÕES } \\
\text { RELACIONADAS }\end{array}$ & AUTOR \\
\hline $\begin{array}{l}1706 \\
\text { (Figura 9) }\end{array}$ & $\begin{array}{l}\text { Zee en Land Reyse } \\
\text { na Bresil, Rio de la } \\
\text { Plata en de Zuyd Zee }\end{array}$ & $\begin{array}{l}\text { Jornada por terra e mar } \\
\text { pelo Brasil depois Rio de } \\
\text { La Plata e o Mar do Sul }\end{array}$ & $\begin{array}{l}\text { Leiden / } \\
\text { Holanda - } \\
\text { Espanhol }\end{array}$ & $\begin{array}{l}\text { R. Parana } \\
\text { Topografias }\end{array}$ & $\begin{array}{l}\text { Aa, } \\
\text { Pieter } \\
\text { van der }\end{array}$ \\
\hline $\begin{array}{l}1729 \\
\text { II } \\
\text { (Figura 10) }\end{array}$ & $\begin{array}{l}\text { A Map of Terra Firma, } \\
\text { Peru, Amazone-land, } \\
\text { Brasil \& The North P. } \\
\text { of La Plata }\end{array}$ & $\begin{array}{l}\text { Um mapa de Tierra } \\
\text { Firme, Peru, Terra } \\
\text { Amazônica, Brasil e o } \\
\text { norte de La Plata }\end{array}$ & $\begin{array}{l}\text { Londres / } \\
\text { Inglaterra - } \\
\text { Inglês }\end{array}$ & $\begin{array}{l}\text { Rio Paraguay; } \\
\text { Rio Parana; } \\
\text { St Paul; St } \\
\text { Vincent; Rich } \\
\text { Gold Mines }\end{array}$ & $\begin{array}{l}\text { Moll, } \\
\text { Herman }\end{array}$ \\
\hline $\begin{array}{l}1732 \\
\text { III } \\
\text { (Figura 11) }\end{array}$ & $\begin{array}{l}\text { Carte de la Terre } \\
\text { Ferme, du Peru, du } \\
\text { Bresil, et du Pays des } \\
\text { Amazones dress ée } \\
\text { sur les mémoires les } \\
\text { pus nouveaux \& les }\end{array}$ & $\begin{array}{l}\text { Mapa de Tierra Firme, do } \\
\text { Peru, do Brasil, e do país } \\
\text { do Amazonas } \\
\text { sobrepostas as } \\
\text { novidades }\end{array}$ & $\begin{array}{l}\text { Amsterdã / } \\
\text { Holanda - } \\
\text { Francês }\end{array}$ & $\begin{array}{l}\text { R. Parana; } \\
\text { Tupinikinsi }\end{array}$ & $\begin{array}{l}\text { Chatelai } \\
\text { n, Henri } \\
\text { Abraha } \\
\mathrm{m}\end{array}$ \\
\hline $\begin{array}{l}1750 \\
\text { IV } \\
\text { (Figura 12) }\end{array}$ & $\begin{array}{l}\text { Carta Geográfica del } \\
\text { Brésil }\end{array}$ & $\begin{array}{l}\text { Mapa Geográfico do } \\
\text { Brasil }\end{array}$ & $\begin{array}{l}\text { Veneza } \\
\text { / Itália - } \\
\text { Italiano }\end{array}$ & $\begin{array}{l}\text { Fiume Parana; } \\
\text { Topografias; } \\
\text { Região retratada } \\
\text { conforme a carta } \\
\text { de Amsterdã, } \\
\text { acrescida a } \\
\text { topografia. }\end{array}$ & $\begin{array}{l}\text { Delisle, } \\
\text { Guillau } \\
\text { me }\end{array}$ \\
\hline $\begin{array}{l}1775 \\
\text { V } \\
\text { (Figura 13) }\end{array}$ & $\begin{array}{l}\text { A Map of South } \\
\text { America }\end{array}$ & $\begin{array}{l}\text { Um Mapa da América do } \\
\text { Sul }\end{array}$ & $\begin{array}{l}\text { Londres / } \\
\text { Inglaterra - } \\
\text { Inglês }\end{array}$ & $\begin{array}{l}\text { Rio Grande; Rio } \\
\text { Paranaiba; Rio } \\
\text { das Velhas; } \\
\text { Topografia. }\end{array}$ & $\begin{array}{l}\text { D'Anvil } \\
\text { le, Jean } \\
\text { Baptiste } \\
\text { Bourgui } \\
\text { gnon }\end{array}$ \\
\hline $\begin{array}{l}1796 \\
\text { VI } \\
\text { (Figura 14) }\end{array}$ & $\begin{array}{l}\text { General Map of South } \\
\text { America From the } \\
\text { Best Surveys }\end{array}$ & $\begin{array}{l}\text { Mapa Geral da América } \\
\text { do Sul a partir das } \\
\text { melhores pesquisas }\end{array}$ & $\begin{array}{l}\text { Nova } \\
\text { lorque / } \\
\text { EUA - } \\
\text { Inglês }\end{array}$ & $\begin{array}{l}\text { Parana R.; R. das } \\
\text { Mortes; Vila } \\
\text { Rica; S. Juan del } \\
\text { Rey; Topografia. }\end{array}$ & $\begin{array}{l}\text { Reid, } \\
\text { John }\end{array}$ \\
\hline $\begin{array}{l}1796 \\
\text { VII } \\
\text { (Figura 15) }\end{array}$ & $\begin{array}{l}\text { Mostrace neste mapa } \\
\text { o Julgado das } \\
\text { Cabeceiras do Rio } \\
\text { das velhas e parte da } \\
\text { Capitania de Minas } \\
\text { Geraes com a devisa } \\
\text { de ambas as } \\
\text { Capitanias dado pelo } \\
\text { Capitam }\end{array}$ & $\begin{array}{l}\text { Mostra-se neste mapa o } \\
\text { Julgado das Cabeceiras } \\
\text { do Rio das Velhas e } \\
\text { parte da Capitania de } \\
\text { Minas Gerais com a } \\
\text { divisa de ambas as } \\
\text { Capitanias dada pelo } \\
\text { Capitão }\end{array}$ & $\begin{array}{l}\text { Minas } \\
\text { Gerais / } \\
\text { Brasil - } \\
\text { Português }\end{array}$ & $\begin{array}{l}\text { Julgado do R. } \\
\text { das Velhas } \\
\text { Rio das Velhas } \\
\text { Rio Grande } \\
\text { Rio Quebra- } \\
\text { anzoes } \\
\text { Barreiro }\end{array}$ & $\begin{array}{l}\text { Rocha, } \\
\text { José } \\
\text { Joaquim } \\
\text { da }\end{array}$ \\
\hline $\begin{array}{l}1826 \\
\text { VIII } \\
\text { (Figura 16) }\end{array}$ & $\begin{array}{l}\text { Carta Corografica } \\
\text { Plana da Provincia de } \\
\text { Goyas e dos } \\
\text { Julgados de ARAXÁ } \\
\text { e DESEMBOQUE da } \\
\text { Provincia de Minas } \\
\text { Gerais }\end{array}$ & $\begin{array}{l}\text { Carta Corográfica Plana } \\
\text { da Província de Goiás e } \\
\text { dos Julgados de ARAXÁ } \\
\text { e DESEMBOQUE da } \\
\text { Província de Minas } \\
\text { Gerais }\end{array}$ & $\begin{array}{l}\text { Goyaz / } \\
\text { Brasil - } \\
\text { Português }\end{array}$ & Araxá & $\begin{array}{l}\text { Matos, } \\
\text { Raimun } \\
\text { do José } \\
\text { da } \\
\text { Cunha }\end{array}$ \\
\hline FONTES: $B i b$ & eca Nacional do Bras & Biblioteca Virtual da & rafia $\mathrm{His}$ & ca do Século XV & ao $X V$ \\
\hline
\end{tabular}

Quadro 1 - Principais Obras Cartográficas Coloniais e Imperiais Relacionadas ao Território de Araxá - 1706 a 1826.

FONTE: BORGES, 2015. 
CARTOGRAFIA DA FORMAÇÃO TERRITORIAL DE ARAXÁ - MINAS GERAIS - DO SERTÃO KAYAPÓ AO TRIÂNGULO MINEIRO E ALTO PARANAÍBA - HERANÇAS HISTORIOGRÁFICAS E BASES DA GÊNESE NO TERRITÓRIO DE CONFLITO.

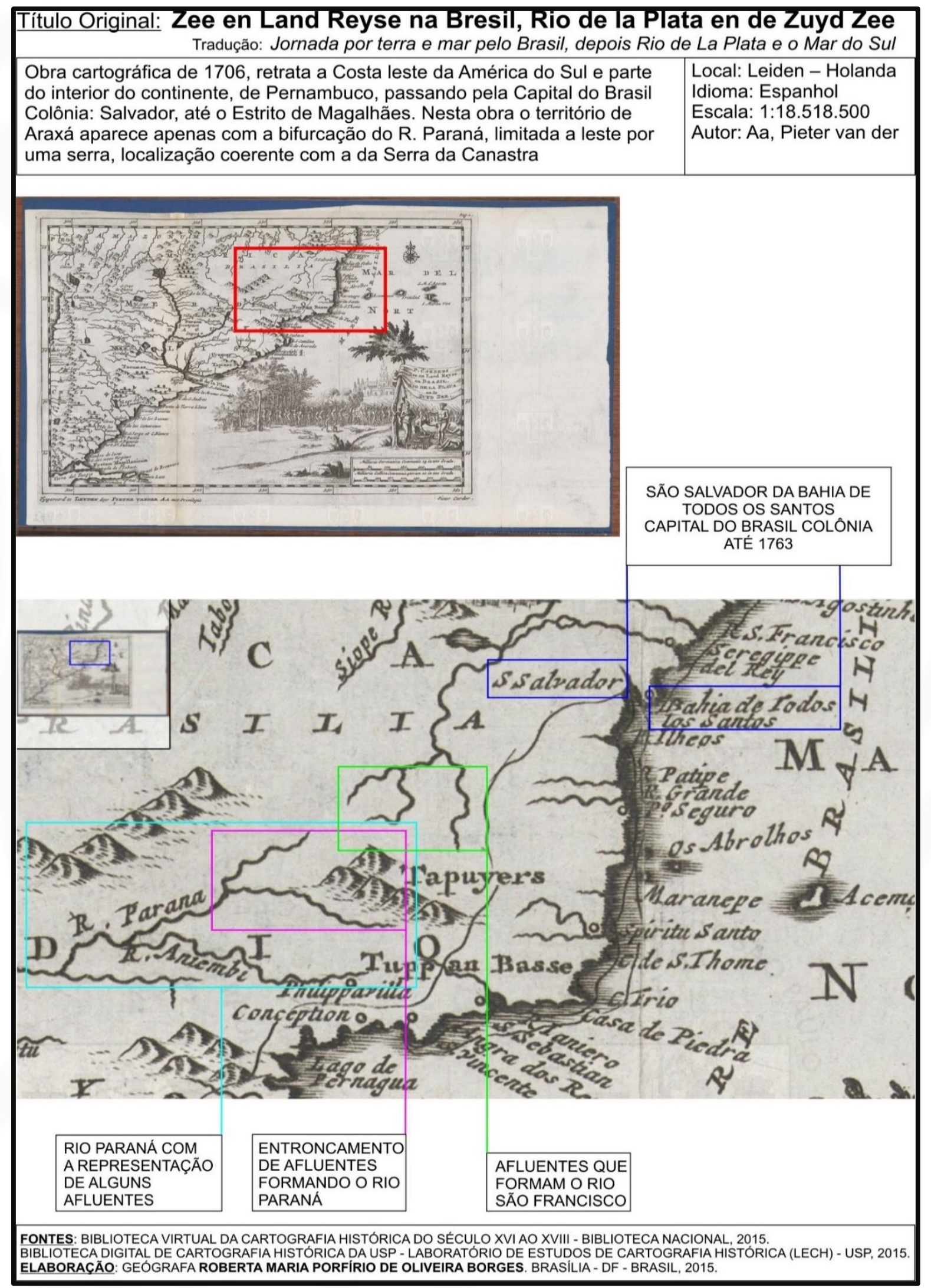

Figura 6 - Zee en Land Reyse na Bresil, Rio de la Plata en de Zuyd Zee - 1706. FONTE: BORGES, Roberta Maria Porfírio De Oliveira. Cartografia e Território de Araxá - MG: Passado e Presente. Uma Leitura e Representação Preliminar, 2015. 
CARTOGRAFIA DA FORMACÃO TERRITORIAL DE ARAXÁ - MINAS GERAIS - DO SERTÃO KAYAPÓ AO TRIÂNGULO MINEIRO E ALTO PARANAÍBA - HERANÇAS HISTORIOGRÁFICAS E BASES DA GÊNESE NO TERRITÓRIO DE CONFLITO.

\section{Título Original: A Map of Terra Firma, Peru, Amazone-land, Brasil \& The North P. of La Plata Tradução: Um mapa de Tierra Firme, Peru, Terra Amazônica, Brasil e o norte de La Plata \\ Obra cartográfica de 1729, retrata a América do Sul com detalhamento do interior do continente. Nesta obra o território de Araxá pode ser localizado apenas pela cabeceira do R. Paraná. Há um lugar próximo descrito como "Rich Gold Mines", ao norte de "S. Paul" e "S. Vincent". Destaque para a localização representada como fronteira entre Brasil e "The North Part of La Plata". \\ Local: Londres - Inglaterra Idioma: Inglês \\ Escala: $1: 22.000 .000$ \\ Autor: Moll, Herman}

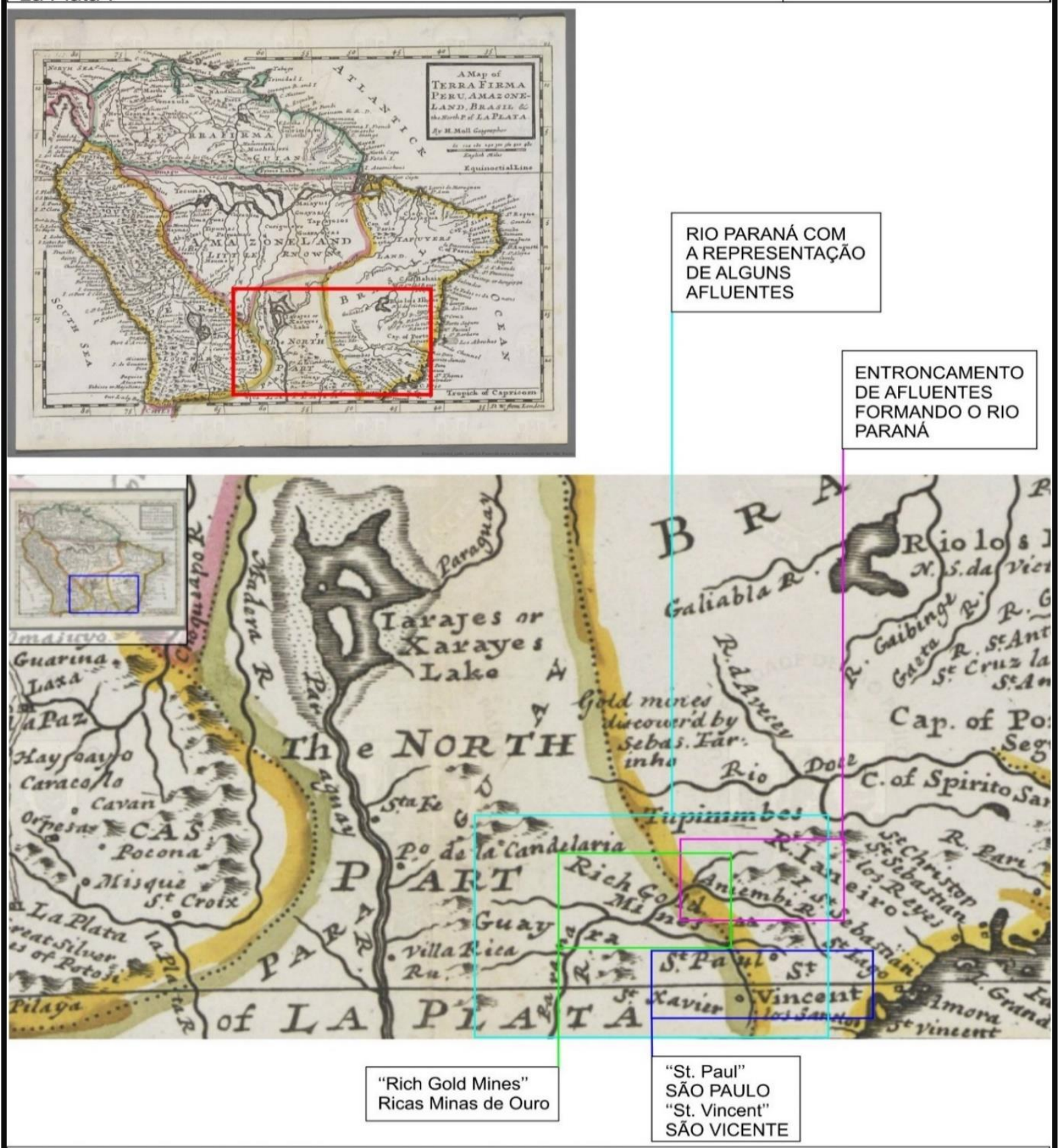

FONTES: BIBLIOTECA VIRTUAL DA CARTOGRAFIA HISTÓRICA DO SÉCULO XVI AO XVIII - BIBLIOTECA NACIONAL, 2015.

BIBLIOTECA DIGITAL DE CARTOGRAFIA HISTÓRICA DA USP - LABORATÓRIO DE ESTUDOS DE CARTOGRAFIA HISTORICA (LECH) - USP, 2015 ELABORAÇĀO: GEÓGRAFA ROBERTA MARIA PORFIRIO DE OLIVEIRA BORGES. BRASILIA - DF - BRASIL, 2015.

Figura 7 - - A Map of Terra Firma, Peru, Amazone-land, Brasil \& The North P. of La Plata - 1729.

FONTE: BORGES, Roberta Maria Porfírio De Oliveira. Cartografia e Território de Araxá - MG: Passado e Presente. Uma Leitura e Representação Preliminar, 2015. 
Título Original: Carte de la Terre Ferme, du Peru, du Bresil, et du Pays des Amazones dress ée sur les mémoires les pus nouveaux \& les Tradução: Mapa de Tierra Firme, do Peru, do Brasil, e do país do Amazonas sobrepostas as novidades

Obra cartográfica de 1732, retrata o entro e o norte da América do Sul com parte do interior do continente. Nesta obra o território de Araxá aparece em um vazio com a inscrição "Tupinikinsi" na nascente do R Paraná.
Local: Amsterdã -

Holanda

Idioma: Francês

Escala: $1: 11.595 .775,46$

Autor: Chatelain, Henri Abraham

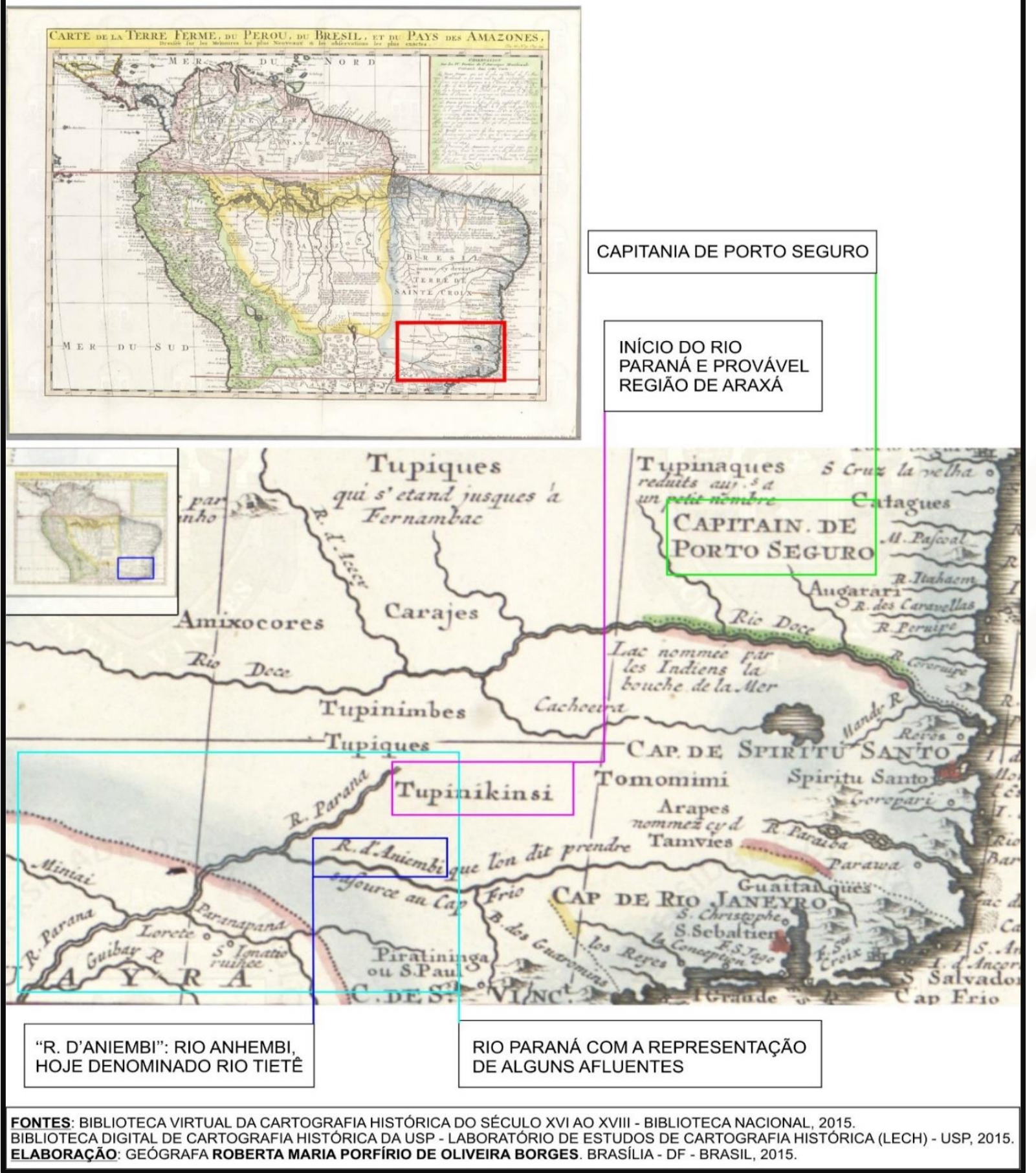

Figura 8 - Carte de la Terre Ferme, du Peru, du Bresil, et du Pays des Amazones dress ée sur les mémoires les pus nouveaux \& les - 1732 .

FONTE: BORGES, Roberta Maria Porfírio De Oliveira. Cartografia e Território de Araxá - MG: Passado e Presente. Uma Leitura e Representação Preliminar, 2015. 
CARTOGRAFIA DA FORMAC̄̃O TERRITORIAL DE ARAXÁ - MINAS GERAIS - DO SERTÃO KAYAPÓ AO TRIÂNGULO MINEIRO E ALTO PARANAÍBA - HERANÇAS HISTORIOGRÁFICAS E BASES DA GÊNESE NO TERRITÓRIO DE CONFLITO.

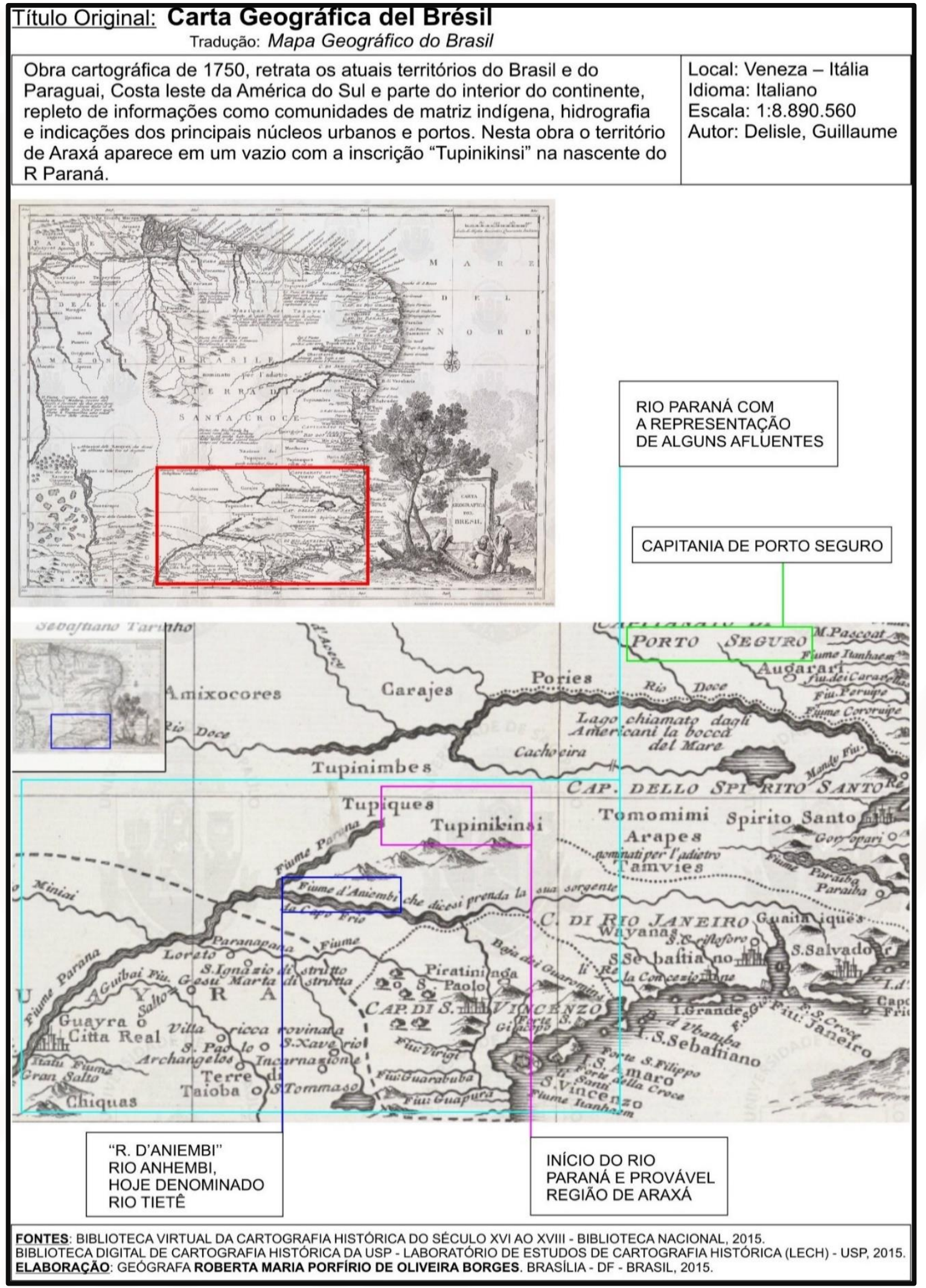

Figura 9 - Carta Geográfica del Brésil - 1750.

FONTE: BORGES, Roberta Maria Porfírio De Oliveira. Cartografia e Território de Araxá - MG: Passado e Presente. Uma Leitura e Representação Preliminar, 2015. 
CARTOGRAFIA DA FORMAC̄̃O TERRITORIAL DE ARAXÁ - MINAS GERAIS - DO SERTÃO KAYAPÓ AO TRIÂNGULO MINEIRO E ALTO PARANAÍBA - HERANÇAS HISTORIOGRÁFICAS E BASES DA GÊNESE NO TERRITÓRIO DE CONFLITO.

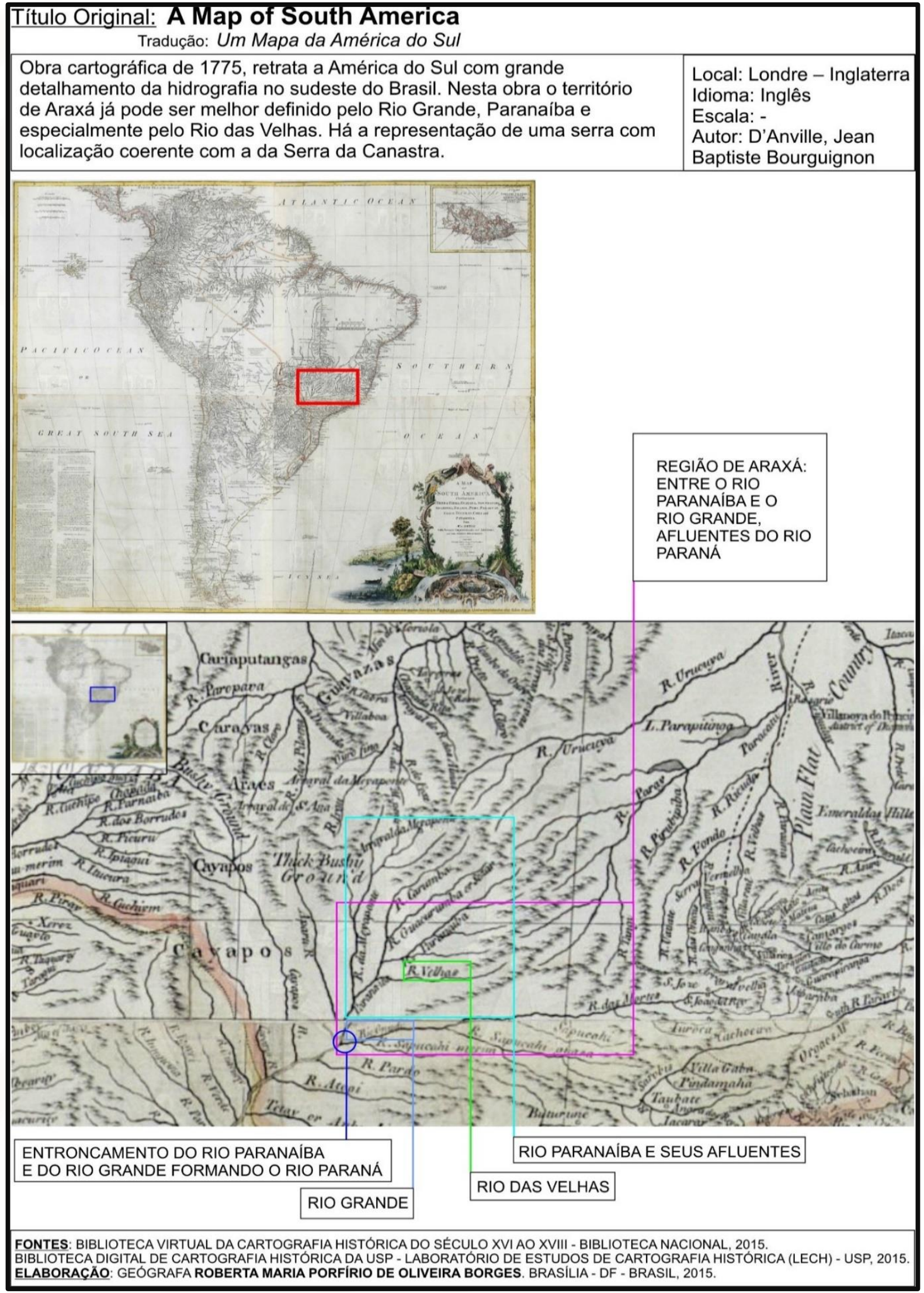

Figura 10 - A Map of South America - 1775.

FONTE: BORGES, Roberta Maria Porfírio De Oliveira. Cartografia e Território de Araxá - MG: Passado e Presente. Uma Leitura e Representação Preliminar, 2015. 
CARTOGRAFIA DA FORMACÃO TERRITORIAL DE ARAXÁ - MINAS GERAIS - DO SERTÃO KAYAPÓ AO TRIÂNGULO MINEIRO E ALTO PARANAÍBA - HERANÇAS HISTORIOGRÁFICAS E BASES DA GÊNESE NO TERRITÓRIO DE CONFLITO.

\section{Título Original: General Map of South America From the Best Surveys \\ Obra cartográfica de 1796, retrata a América do Sul, com hidrografia e relevo do interior do continente. Nesta obra, apesar de mais nova que a de 1775 , o território de Araxá aparece apenas com a cabeceira do R. Paraná, sem que este esteja nomeado na carta.}

Tradução: Mapa Geral da América do Sul a partir das melhores pesquisas
Local: Nova lorque Estados Unidos da América Idioma: Inglês

Escala: 1:23.191.551 Autor: Reid, John

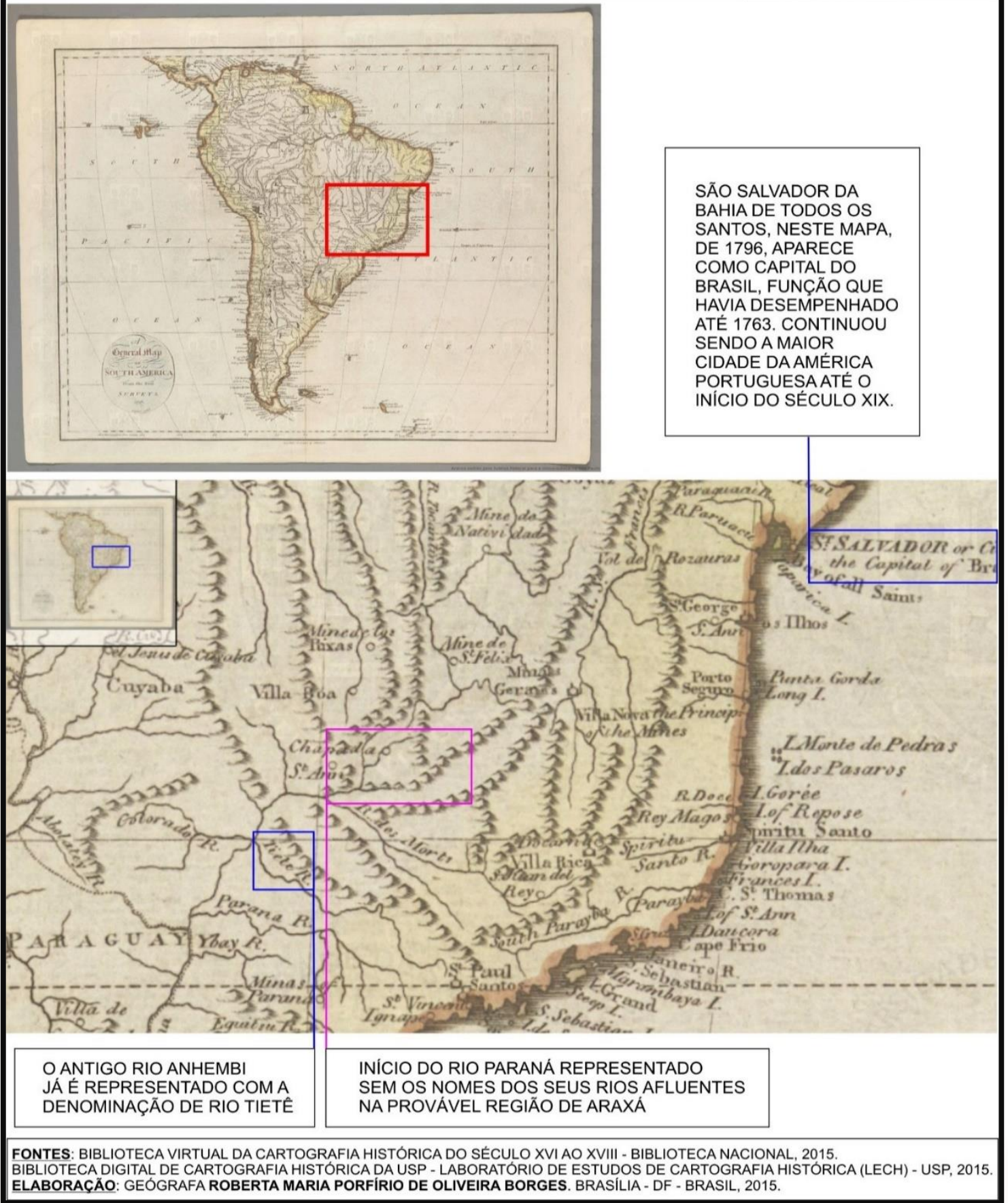

Figura 11 - General Map of South America From the Best Surveys - 1796. FONTE: BORGES, Roberta Maria Porfírio De Oliveira. Cartografia e Território de Araxá - MG: Passado e Presente. Uma Leitura e Representação Preliminar, 2015. 
Título Original: Mostrace neste mapa o Julgado das Cabeceiras do Río das velhas e parte da Capitania de Minas Geraes com a devisa de ambas as

Capitanias dado pelo Capitam

Tradução: Mostra-se neste mapa o Julgado das Cabeceiras do Rio das Velhas e parte da Capitania de Minas Gerais com a divisa de ambas as Capitanias dada pelo Capitão

Obra cartográfica de 1796, retrata detalhadamente parte da Capitania de Minas Geraes e especialmente as cabeceiras do Rio das Velhas, do Julgado do mesmo nome, este na divisa da Capitania de Minas Geraes com a Capitania de Goyaz. Nesta obra o território de Araxá aparece em detalhe, onde na região entre o Rio Grande e o Rio Paranaíba, há o Rio das Velhas e o Rio Quebra-anzol, além do Julgado do Rio das Velhas, o Barreiro do Araxâs, a Serra do Aracha e a Serra da Canastra.

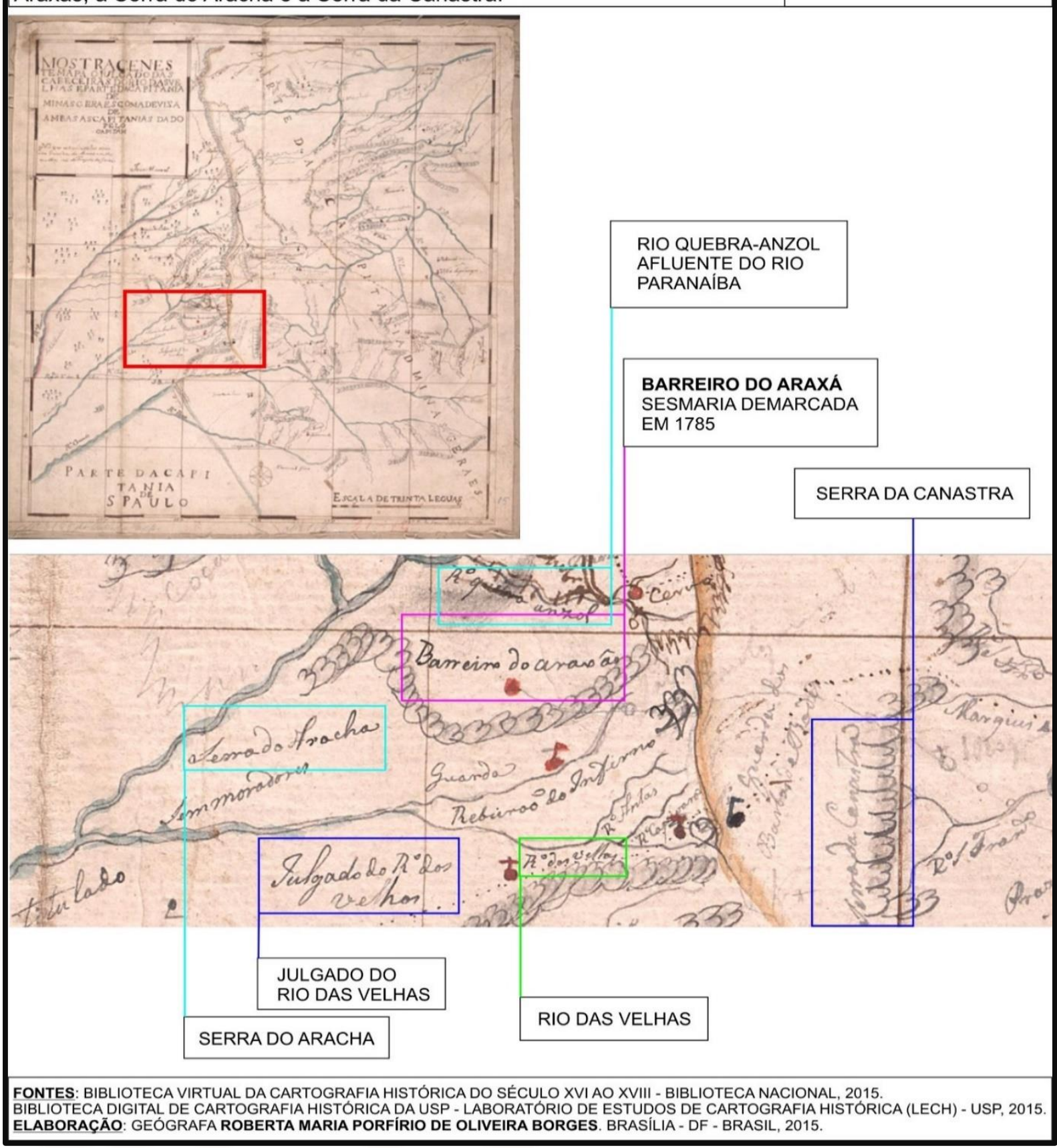

Figura 12 - Mostrace neste mapa o Julgado das Cabeceiras do Rio das Velhas e parte da Capitania de Minas Geraes - 1796.

FONTE: BORGES, Roberta Maria Porfírio De Oliveira. Cartografia e Território de Araxá - MG: Passado e Presente. Uma Leitura e Representação Preliminar, 2015.

BORGES, Roberta Maria Porfírio de Oliveira. 2018. 


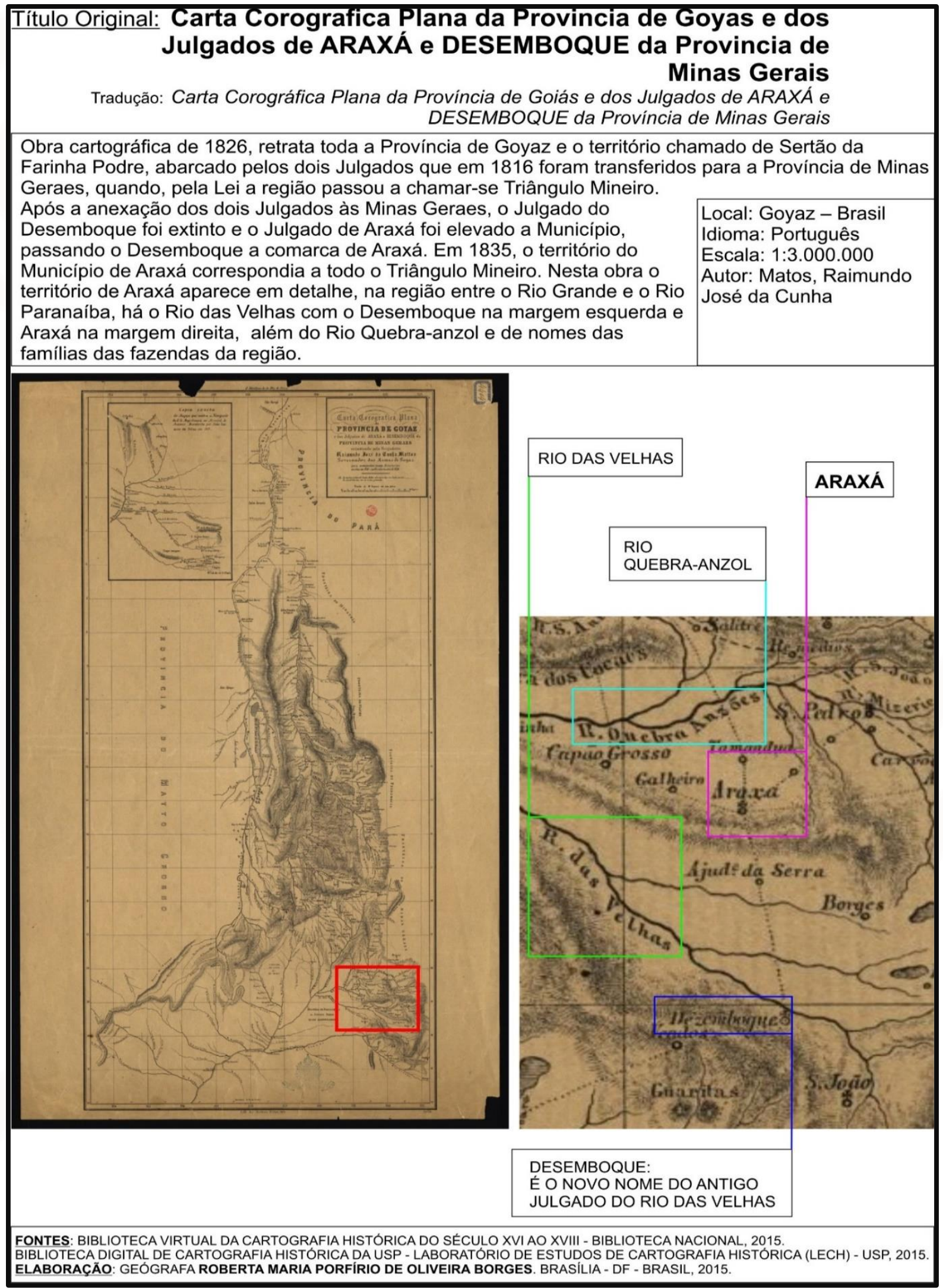

Figura 13 - Carta Corografica Plana da Provincia de Goyaz e dos Julgados de ARAXÁ e DESEMBOQUE da Provincia de Minas Gerais - 1826.

FONTE: BORGES, Roberta Maria Porfírio De Oliveira. Cartografia e Território de Araxá - MG: Passado e Presente. Uma Leitura e Representação Preliminar, 2015. 
Destaca-se o elevado nível de detalhamento e precisão das obras lusobrasileiras em relação as demais, a diferença pode ser observada especialmente entre as cartas Mostrace neste mapa o Julgado das Cabeceiras do Rio das velhas e parte da Capitania de Minas Geraes com a devisa de ambas as Capitanias dado pelo Capitam (Obra no VII - Figura 15) e General Map of South America From the Best Surveys (Obra no VI - Figura 14), que foram produzidas no mesmo ano. A Carta Corografica Plana da Provincia de Goyaz e dos Julgados de ARAXÁ e DESEMBOQUE da Provincia de Minas Gerais (Figura 16) também merece destaque, ao trazer em uma carta com escala 1: 3.000.000 de 1826 uma representação detalhada de caminhos, principais localidades, hidrografia e relevo da região de Araxá daquela época.

\section{A Cartografia Histórica como referência e fonte de DADOS NA PESQUISA}

\section{Das localizações das nações e povos indígenas no território para Conexão Cronológica da Cartografia da Formação Territorial de Araxá}

A partir da Carta America Meridionalis in suas praecipuas Partes Accuratè Divisa, ad Usum Serenissini Burgundiae Ducis 'L'Amerique Meridionale Divisée em Ses Principales Parties. Hlaillat, 1696 foram aferidas as localizações aproximadas das nações e povos indígenas representadas no ano de 1696 na configuração territorial do século XVII, da qual são constatadas as informações da Configuração Política do Território. É realizada uma Projeção Aproximada destas informações na realização de uma cartografia atual, considerando as diferenças de projeção cartográfica e buscando as referências físicas e toponímicas entre a Cartografia Histórica e a atualidade. Esta cartografia histórica também permite aferir uma espacialização aproximada dos Povos de Matriz Indígena no território no século XVII, dando base para a projeção desta espacialização na Cartografia da Formação Territorial de Araxá.

\section{Das fronteiras da Província do Paraguay e da Província do Grão-Pará Conexão Cronológica da Cartografia da Formação Territorial de Araxá}

A partir da Carta America Meridionalis in suas praecipuas Partes Accuratè Divisa, ad Usum Serenissini Burgundiae Ducis 'L'Amerique Meridionale Divisée em

BORGES, Roberta Maria Porfírio de Oliveira. 2018. 
Ses Principales Parties. Hlaillat, 1696 foram aferidas as fronteiras da Província do Paraguay, da Província do Grão-Pará e das demais unidades administrativas da configuração territorial decorrente dos processos desencadeados durante a União Ibérica (1580-1640). Estas fronteiras foram projetadas na Cartografia da Formação Territorial de Araxá, levando em consideração as diferenças de projeção cartográfica entre a cartografia histórica e a Cartografia atual, desenvolvida nesta pesquisa e considerando os elementos da cartografia, como a toponímia para auxiliar a projeção, permitindo uma visualização aproximada da configuração das unidades administrativas da época representada.

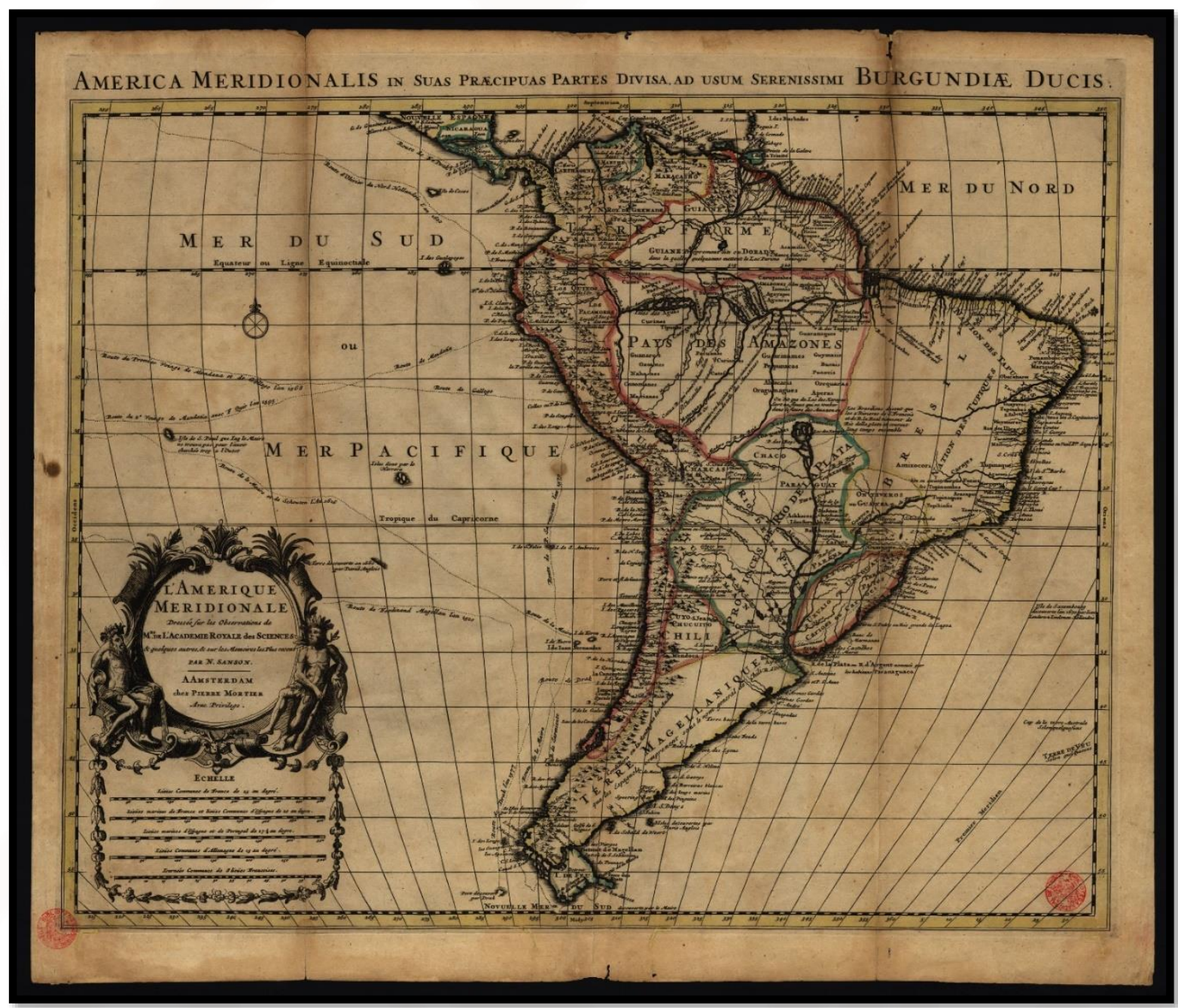

Figura 14 - Cartografia Histórica para aferir localização de Povos e Nações Indígenas. 


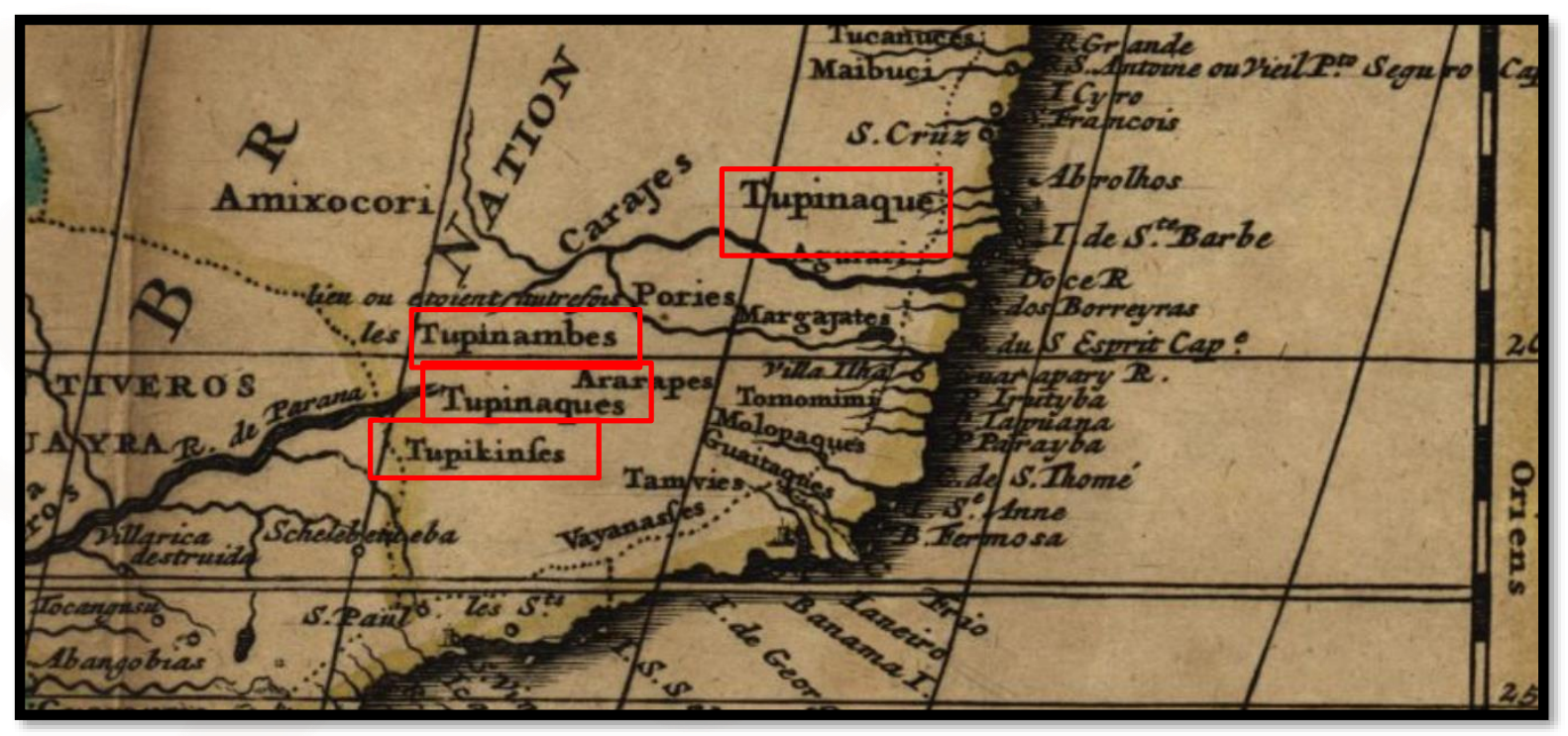

Figura 15 - Detalhe da Cartografia Histórica para aferir localização de Povos e Nações Indígenas.

\section{Dos núcleos urbanos para Conexão Cronológica da Cartografia da Formação Territorial de Araxá}

Na Carta Mappa da Comarca do Rio das Mortes pertencente a Capitania de Minas Geraes, $1777^{*}$ foram aferidos os núcleos urbanos representados, assim como as fazendas representadas que posteriormente tornaram-se núcleos urbanos, como por exemplo: Formiga.

Considerando que Núcleos representados nesta carta de 1777, evidentemente já existiam em 1777, cada nome foi pesquisado, buscando o histórico do núcleo representado na carta, para assim identificar as datas e formas de surgimento, desenvolvimento e denominação do núcleo no decorrer do tempo histórico.

Os núcleos que tiveram o histórico identificado com sucesso na aferição de data de surgimento precedente à data da Carta da Comarca do Rio das Mortes*, ou seja, a data precedente a 1777, foram representados de acordo com as datas encontradas, sendo Ibituruna o Núcleo Urbano representado na carta com data mais antiga identificada: 1674, segundo MARTINS (2008) e PARANHOS (2005). É certo que os demais núcleos que são representados têm surgimento precedente ao registro na Carta, mas, como não foi identificada a data de surgimento dos mesmos, consideramos 1777, por ser a data do documento em que primeiro aparecem nesta 
pesquisa, a Mappa da Comarca do Rio das Mortes pertencente a Capitania de Minas Geraes, 1777*.

\section{Dos caminhos, estradas e picadas entre os núcleos urbanos para Conexão Cronológica da Cartografia da Formação Territorial de Araxá}

Na Carta Mappa da Comarca do Rio das Mortes pertencente a Capitania de Minas Geraes, $1777^{*}$ foram aferidos os caminhos, estrada e picadas entre núcleos urbanos e fazendas representados. Depois estes caminhos foram projetados na Cartografia da Formação Territorial de Araxá.

\footnotetext{
* ROCHA, Joaquim José da. Mappa da Comarca do Rio das Mortes pertencente a Capitania de Minas Geraes que mandou descrever o Illustrissimo e Excellentissimo Senhor D. Antonio de Noronha Governador e Capitam General da mesma Capitania, segundo as mais exactas informaçoens. Anno de 1777. Capitania de Minas Geraes. 1777.
}

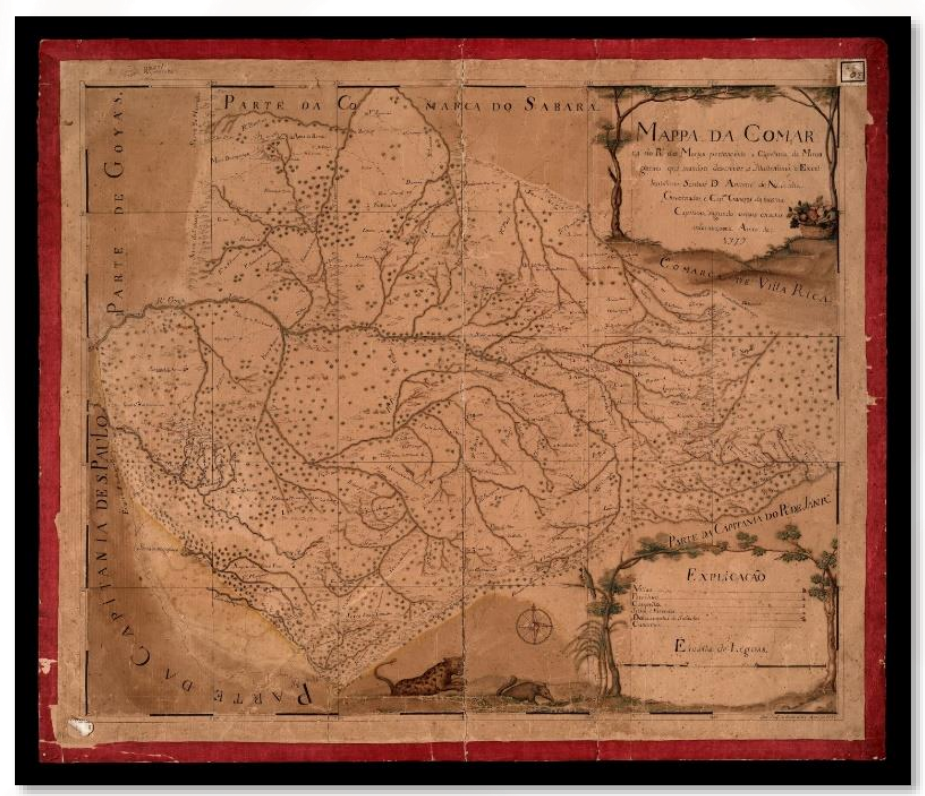

Figura 16 - Cartografia Histórica para aferir Estradas, Picadas e Caminhos. 
CARTOGRAFIA DA FORMACÃO TERRITORIAL DE ARAXÁ - MINAS GERAIS - DO SERTÃO KAYAPÓ AO TRIÂNGULO MINEIRO E ALTO PARANAÍBA - HERANÇAS HISTORIOGRÁFICAS E BASES DA GÊNESE NO TERRITÓRIO DE CONFLITO.

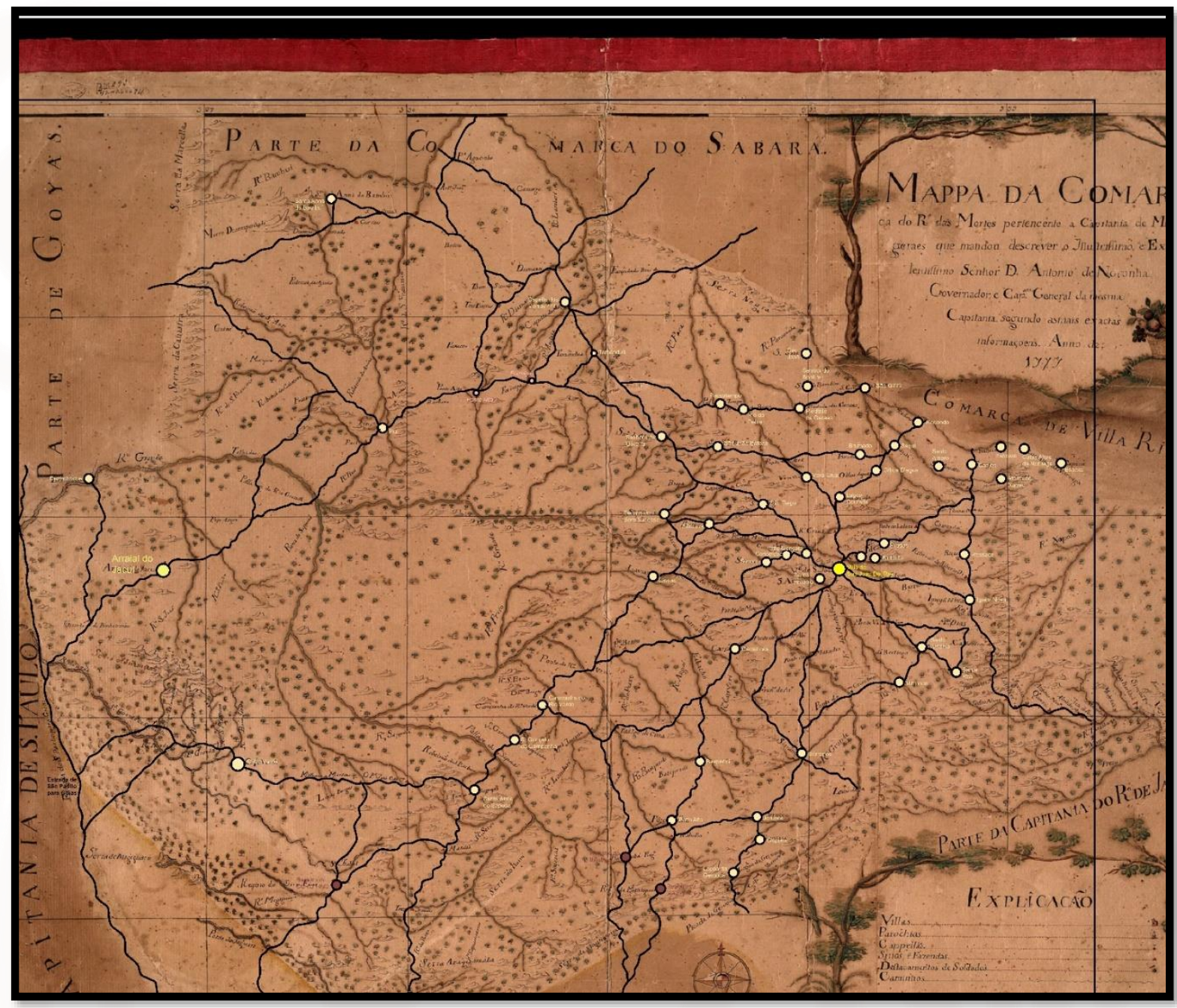

Figura 17 - Detalhe da Cartografia Histórica para aferir Estradas, Picadas e Caminhos. 


\section{Capítulo II - A FORMAÇÃo TERRITORIAL DE}

ARAXÁ

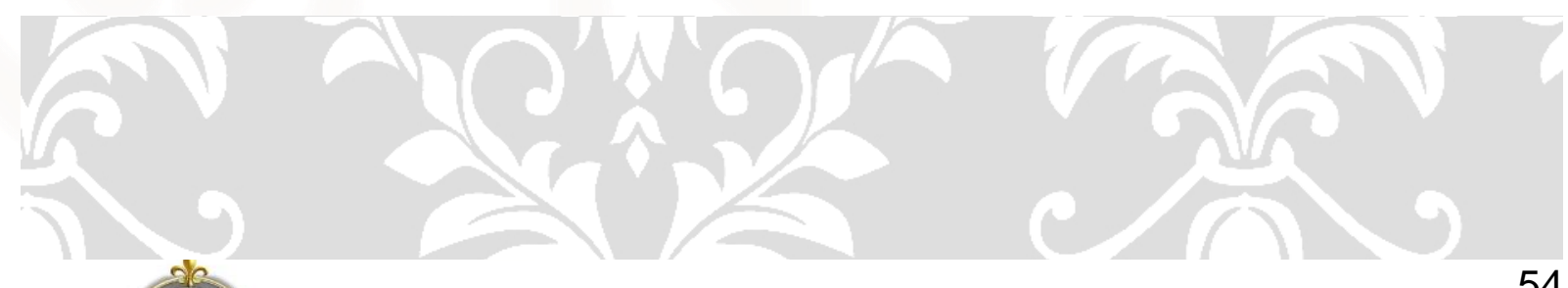

BORGES, Roberta Maria Porfírio de Oliveira. 2018. 


\section{Contextualização Histórica de Araxá}

O comportamento do indivíduo é subordinado e estruturado pelo comportamento social, onde a "liberdade que é frequentemente reconhecida aos agentes não é outra coisa senão sua participação nas praxis coletivas, por intermédio de uma escolha limitada de opções já incluídas na própria estrutura". (SANTOS, 2005). Portanto, conhecer o que faz a estrutura é essencial para entender as principais questões da sociedade.

A formação territorial brasileira expressa forte impacto da era mercantilista na qual o continente sul-americano desempenhou o papel de colônia (1530 - 1815), durante a vigência dessa ordem mundial o território brasileiro era uma posse colonial do Império Ultramarino Português, durante a União Ibérica (1580-1640) foi administrado pela Coroa Espanhola, voltando à posse de Portugal com a restauração da Coroa Portuguesa, passando pelo Reino Unido de Portugal, Brasil e Algarves (1815 - 1822) até o Império do Brasil (1822 - 1889), um período de 359 anos de economia baseada na mão-de-obra escrava (MARTINS, 2008).

A estrutura do sistema escravista manteve-se no território brasileiro por quase quatro séculos. A sociedade escravista estabilizou-se e desenvolveu-se, importando continuamente, até 1850, para as regiões de interesse econômico europeu, os maiores fluxos de negros escravizados (ANJOS, 2000, p 29), "a ponto de se tornar impossível precisar o número de africanos retirados de seu habitat, com sua bagagem cultural, a fim de serem, injustamente, incorporados às tarefas básicas para a formação de uma nova realidade" (ANJOS, 2000, p. 27).

A contiguidade é criadora de comunhão, a política se territorializa, com o confronto entre organização e espontaneidade (SANTOS, 1996, p.218), a escravidão (1530 1888) criou comunhão e se territorializou, compondo a formação territorial brasileira, conforme Santos: "O modelo cívico brasileiro é herdado da escravidão, tanto o modelo cívico cultural, como o modelo cívico político. A escravidão marcou o território, marcou os espíritos e marca ainda hoje as relações sociais deste país" (SANTOS, 1996-1997, p.135).

As noções de espaço e de tempo são enlaçadas, definitivamente, no lugar, onde tudo se funde no cotidiano compartido entre as pessoas, firmas e instituições, pautado

BORGES, Roberta Maria Porfírio de Oliveira. 2018. 
na cooperação e conflito. No lugar se sobrepõem dialeticamente o eixo das sucessões e o eixo das coexistências, assim, a existência do mundo se dá nos lugares. O lugar "é o quadro de uma referência pragmática ao mundo, do qual lhe vêm solicitações e ordens precisas de ações cotidianas" (SANTOS, 1996, p. 218).

Antes da institucionalização das unidades territoriais coloniais locais, o território do Antigo Município de Araxá era referido como Sertão da Farinha Podre. No entanto, esta toponímia, decorrente de histórias de desbravamento do sertão, já era reflexo da presença dos Bandeirantes na Região. Antes da influência das bandeiras, o nome refletia uma territorialidade da região que precedeu a colonização deste território.

Como nos mostra a Cartografia Histórica, por exemplo, o "Mappa dos Sertoes que se comprehendem de mar a mar entre as capitanias de SPaulo Goyazes Cuyaba Mato Grosso e Para", do século XVIII, a Região é nomeada como Certão do Gentio Cayapó.

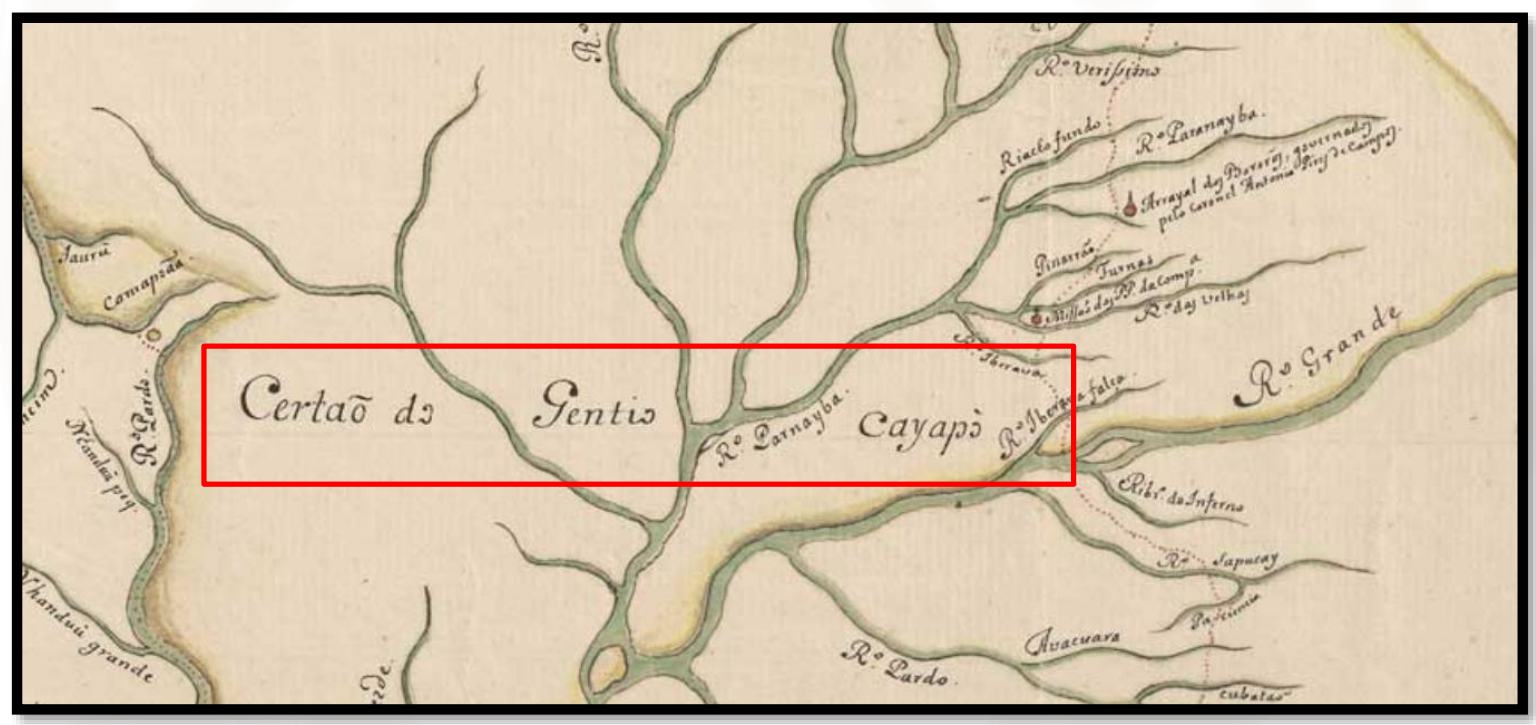

Figura 18 - Destaque da Toponímia Sertão Kayapó na Cartografia Histórica.

A partir da Cartografia Histórica, podemos observar a denominação dada à região na época do contexto de produção do documento cartográfico. 


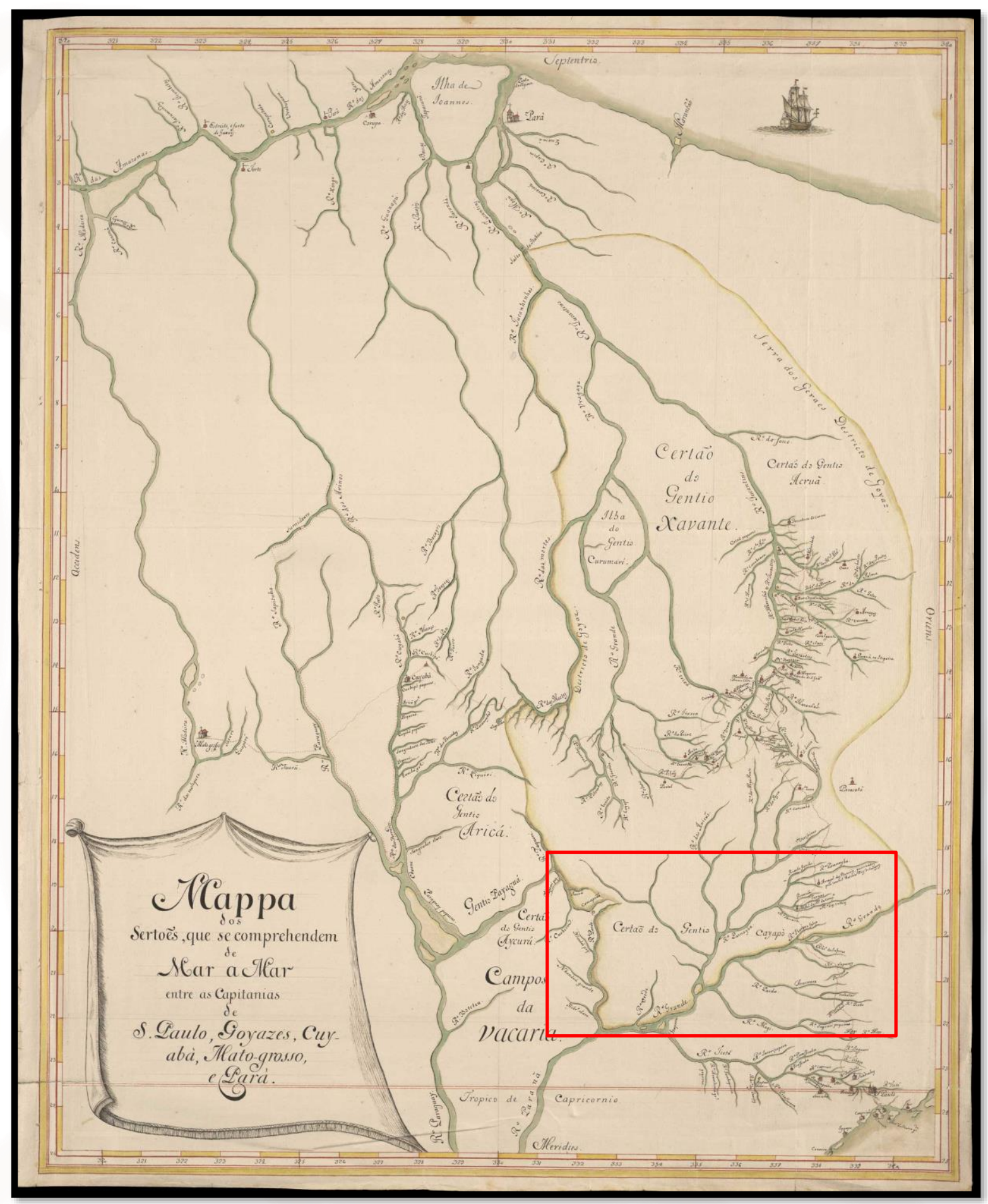

Figura 19 - Localização do Sertão Kayapó na Cartografia Histórica.

Já como Sertão da Farinha Podre, este é conhecido como um lugar que, até a chegada do movimento de resistência dos negros escravizados, os quilombolas, era o refúgio de comunidades de matriz indígena, sendo em 1748 e 1750 descrito no 
Conselho Ultramarino (1642 - 1833) como um "mar de índios do Pai-Pirá". Os quilombos se desenvolveram neste lugar, sendo também o refúgio dos moradores dos quilombos destruídos na Grande Guerra do Campo Grande, especialmente, da Povoação do Ambrósio - Cristais, destruída em 1746. Os índios se aliaram aos negros quilombolas, ajudando nos combates da Guerra do Campo Grande, como no Grande Ataque ao Quilombo do Campo Grande ocorrido no Quilombo do Ambrósio (Ibiá) em 1759-1760 (MARTINS, 2008).

A Política Imperial, visando a mudança do 'pensamento' e das referências coloniais, promoveu a mudança e adoção de diversos nomes. Neste contexto, a região do Sertão da Farinha Podre passou a ser chamada Triângulo Mineiro, as duas localidades mais expressivas politicamente na época também tiveram os nomes de referência modificados. Nossa Senhora do Desterro do Desemboque passou a simplesmente Desemboque e São Domingos do Araxá passou a somente Araxá, e os territórios desses núcleos urbanos passaram a ser Julgado do Desemboque e Julgado do Araxá.

A relação dos eventos da História com o espaço geográfico é íntima, de forma que é difícil separar o espaço do tempo, pois estes confundem-se como produto histórico (ANJOS, 2000, p.14). Um produto histórico deste período no Sertão da Farinha Podre é o sítio Arqueológico do Quilombo do Campo Grande em Ibiá e a territorialização da cultura de matriz africana na região (ANJOS, 2010).

No Sertão da Farinha Podre, os índios que se aliaram aos negros sobreviveram, os que ficaram sozinhos morreram na miséria após a destruição dos quilombos do Campo Grande. Nesta época, embalado pelo ouro e posição geográfica estratégica (caminho de São Paulo para Goiás), surgiu e cresceu o Arraial das Abelhas, depois chamado de Desemboque. Por solicitação dos moradores do Desemboque, em 1766 o Sertão da Farinha Podre é anexado a Capitania de Goiás (MARTINS, 2008).

\section{EvoluçÃo AdMINISTRATIVA InICIAL de ARAXÁ}

Com a demarcação de sesmarias neste Sertão foram formadas as primeiras fazendas de criação de gado e, a partir de 1770, Araxá recebe seus primeiros moradores, em 1780 já estava configurado o Arraial, em 1791 foi criada a Freguesia de São Domingos do Araxá. O declínio da mineração declinou também o Desemboque. O aumento da criação de gado fez o Araxá crescer e se consolidar. 
Elevada a Julgado em 1811, desmembrou-se do Julgado de Desemboque. Conseguiu a anexação do Sertão da Farinha Podre à Capitania de Minas Gerais em 1816, e foi elevada a vila em 1831. No ano de 1835 o município de Araxá abarcava todo o Sertão da Farinha Podre, lugar no qual Araxá foi o primeiro núcleo urbano que vingou e permaneceu, tornando-se oficialmente uma cidade em1865. (ROSA, 2011)

Em 1831 é criado o Município de Araxá. Consolidado, em 1835, o Município de Araxá possuía um território de, aproximadamente, 105.307,01 km², o qual denominamos de o Antigo Município de Araxá, abrangendo toda a região entre os Rios Grande e Paranaíba em extensão superior à que hoje é chamada de Triângulo Mineiro (Ver Capítulo V). O desenvolvimento da região demandou de forma crescente a proximidade da administração dos núcleos urbanos que foram surgindo e se estabelecendo. Em 1836 começou o processo de divisão do Antigo Município de Araxá. (BORGES, 2015, p. 93)

Assim, em pleno sistema escravista, vigorante até 1888, estava instituído o Município de Araxá, cujo território abrangia lugares onde hoje, segundo Anjos (2010, p.12), "as expressões culturais territorializadas, como as Congadas, Ternos de Reis e Moçambiques, são manifestações de referência africana no Brasil e que reafirmam o passado escravocrata e de sobrevivência das matrizes da África no Brasil".

O território do Antigo Município de Araxá (Capítulo V) hoje corresponde aos territórios de 76 municípios do Estado de Minas Gerais, abrangendo todo o território da Mesorregião do Triângulo Mineiro e Alto Paranaíba (66 Municípios) além de partes das Mesorregiões do Noroeste de Minas - municípios de Presidente Olegário, São Gonçalo do Abaeté, Lagamar, Lagoa Grande e Varjão de Minas - e Central Mineira municípios de Abaeté, Morada Nova de Minas, Biquinhas, Paineiras e Cedro do Abaeté - (Capítulo V). Da configuração territorial do Estado brasileiro de Minas Gerais vigente no ano de 2015, que conta com 853 municípios, 76 são oriundos do território do Antigo Município de Araxá, o que corresponde a, aproximadamente, 8,9\% dos municípios do Estado e 1,3\% dos 5.568 municípios do país. (BORGES, 2015, p. 94). 


\section{MUNICÍPIOS DA MICRORREGIÃO DE ARAXÁ 2015 - MINAS GERAIS - BRASIL}

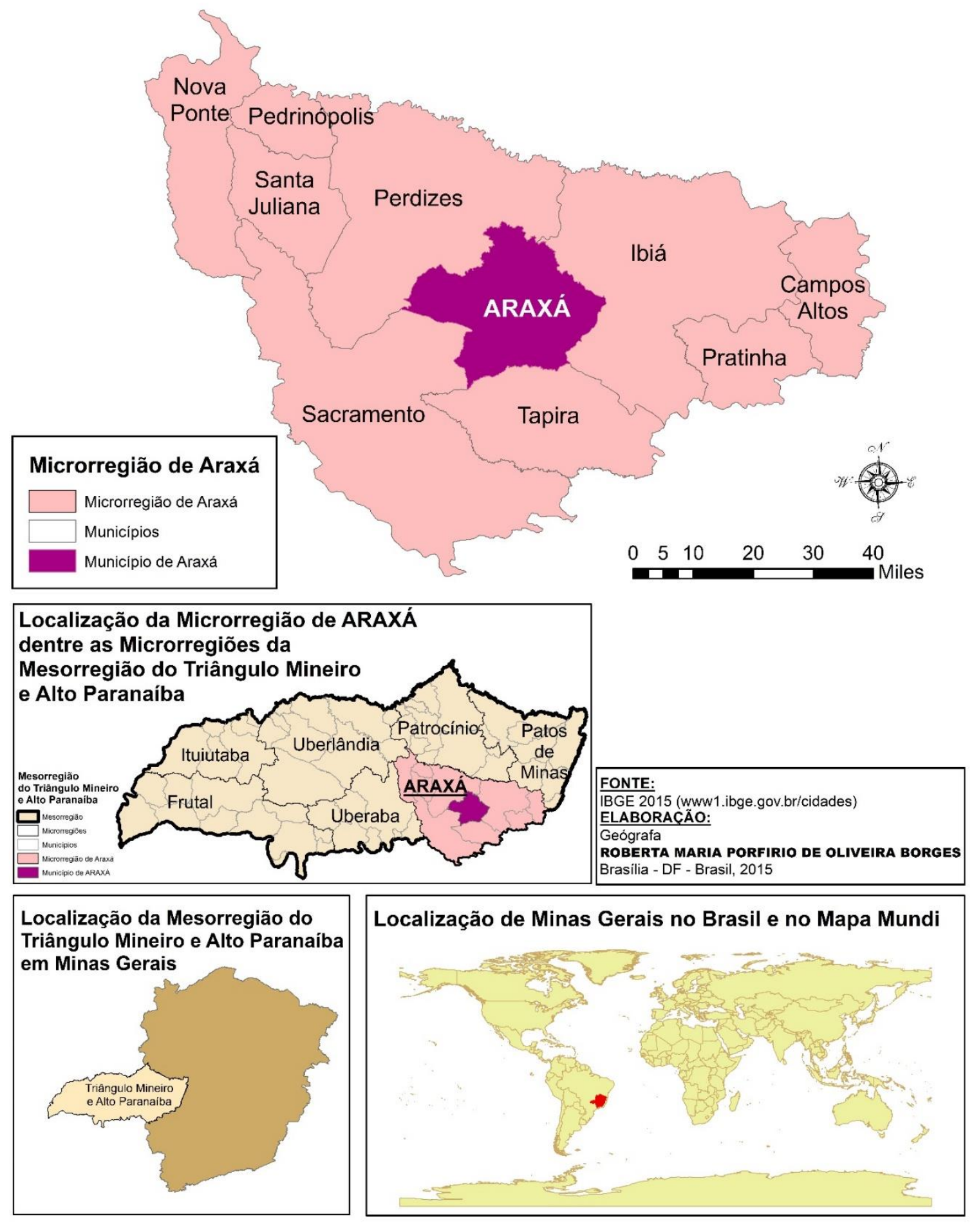

Figura 20 - Município de Araxá. Municípios da Microrregião de Araxá 2015 Minas Gerais Brasil.

Fonte: BORGES, Roberta Maria Porfírio De Oliveira. Cartografia e Território de Araxá - MG: Passado e Presente. Uma Leitura e Representação Preliminar, 2015. 
CARTOGRAFIA DA FORMAÇÃO TERRITORIAL DE ARAXÁ - MINAS GERAIS - DO SERTÃO KAYAPÓ AO TRIÂNGULO MINEIRO E ALTO PARANAÍBA - HERANÇAS HISTORIOGRÁFICAS E BASES DA GÊNESE NO TERRITÓRIO DE CONFLITO.

\section{Capítulo III - TERRITORIALIDADES SOBREPOSTAS} e Resistências no Caminho

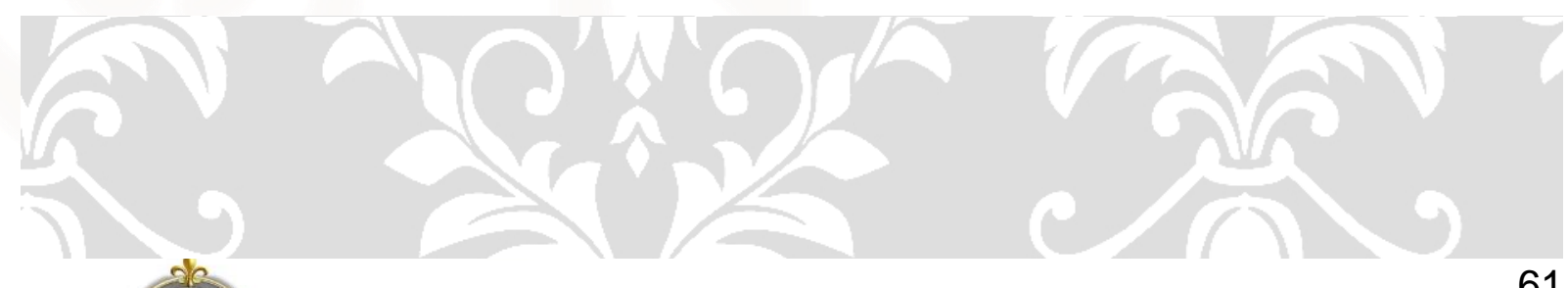


O título deste capítulo: Territorialidades Sobrepostas e Resistências no Caminho expressa elementos do prisma da Formação Territorial que esta pesquisa busca contemplar, considerando que a própria condição de pesquisa realizada no século XXI com objeto secular possui suas limitações e particularidades, dentre aquelas estão as condições de observação paradoxalmente negativas e positivas, como o distanciamento relativo do objeto, distanciamento promovido pela distância temporal de séculos entre a pesquisa e a gênese do objeto e, ao mesmo tempo, proximidade do objeto ao considerar que trata-se de processo que se desenvolve continuamente e cujos efeitos se propagam ao longo do tempo histórico, assim perdurando até a atualidade e quiçá até muitos séculos além.

Dentre as particularidades, está a vantagem do distanciamento temporal, que permite uma perspectiva já amparada por um entendimento do processo macro mundial que regia o objeto estudado, ou seja, o objeto desta pesquisa - a Formação Territorial de Araxá - é um processo, regido por um processo mundial maior que atua neste território na forma da Colonização, com todos os elementos, dinâmicas e efeitos inerentes a ela.

Este processo não acontece de forma isolada ou espontânea, ele deriva de um jogo Multiescalar de interesses e poderes.

Assumindo esta Multiescalaridade de Sistemas, Processos e Ciclos e a inerente característica dos Sistemas, Processos e Ciclos de acontecerem no Espaço e se estenderem ao longo do Tempo, é possível especializar os elementos que expressam esta Dinâmica Multiescalar da Formação Territorial de Araxá ao longo do tempo histórico.

Portanto, a Formação Territorial é influenciada, relacionada, integrada e fruto da dialética entre as diversas escalas, ciclos, processos e sistemas. 


\section{Escalas, Sistemas, Processos e Ciclos Relacionados}

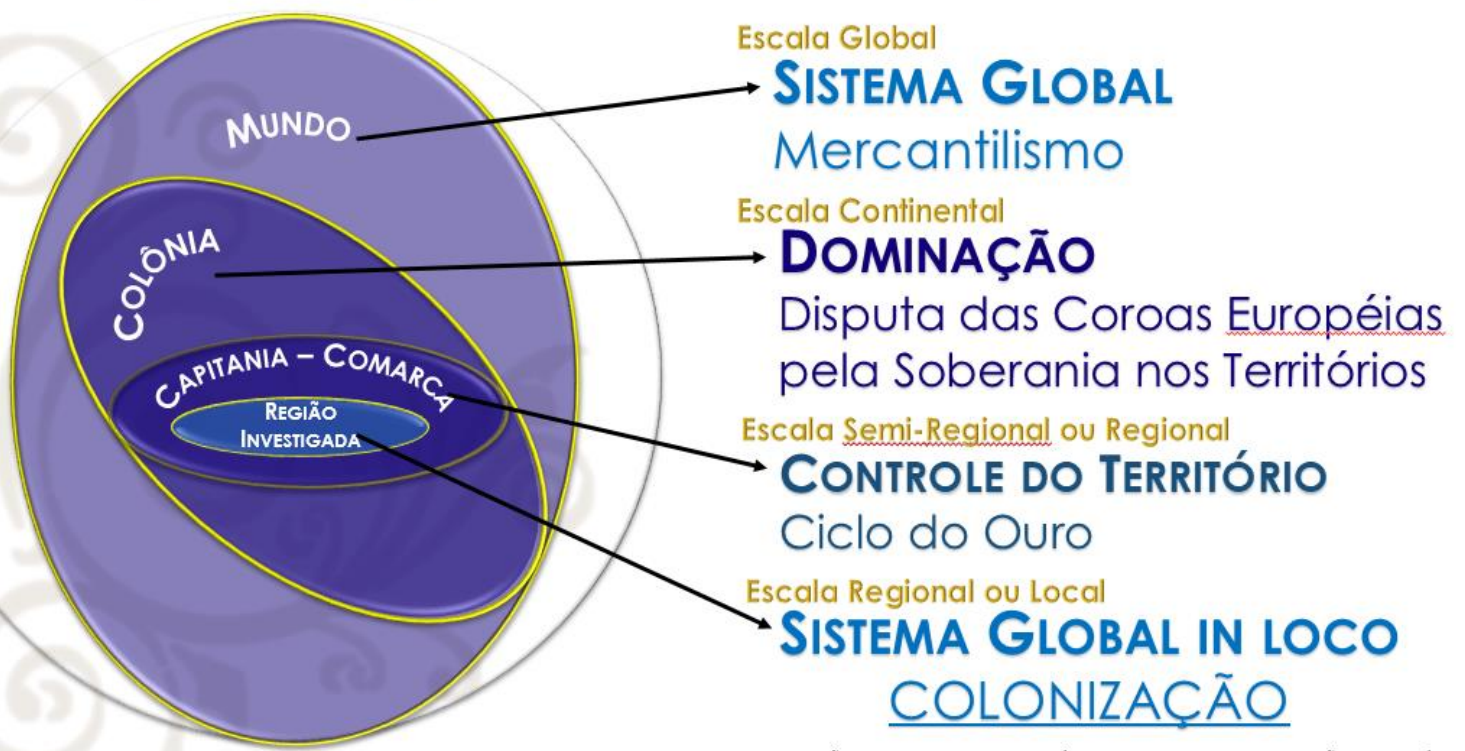

Elaboração: Gé́grafa ROBERTA MARIA PORFíRIO DE OLIVIRA BORGES, 2018. CARTOGRAFIA DA FORMAÇÃO TERRITORIAL DE ARAXÁ - MINAS GERAIS - DO SERTÃO KAYAPÓ AO TRIÂNGULLO MINEIRO E ALTO PARANAÍBA - HERANÇAS HISTORIOGRÁFICAS E BASES DA GÊNESE NO TERRITÓRIO DE CONFLITO.

\section{Figura 21 - Escalas, Sistemas, Processos e Ciclos}

A palavra Caminho neste contexto tem mais de um sentido:

- Caminho, no sentido de Processo de Colonização;

- Caminho, no sentido de Caminho, Picadas e Estradas e

- Caminho, no sentido da condição inicial da Região de Araxá, como espaço de circulação, que ligava o litoral ao interior no desenrolar do ciclo do ouro.

As Resistências têm sua expressão materializada no Conflito. O Conflito existe e evolui para as Guerras como fruto da Resistência ao Sistema Dominante. Diante da Resistência o Sistema Dominante utiliza o combate armado para impor sua dominância. Essas resistências estão no Caminho do Processo de Formação Territorial, na forma e na intensidade da interação entre dominação e dominados no Território, em Processo cujo movimento Espacial define o Território na Dinâmica Territorial.

Assumindo que o processo de Formação Territorial de Araxá deriva do movimento do espaço, que define o território, em dialética com outras escalas, em uma interação de poderes expressa nos ciclos desencadeados pelas ações, aqui bem 
representadas pelas leis, que influenciam o movimento do espaço, a dinâmica territorial e, consequentemente, o território.

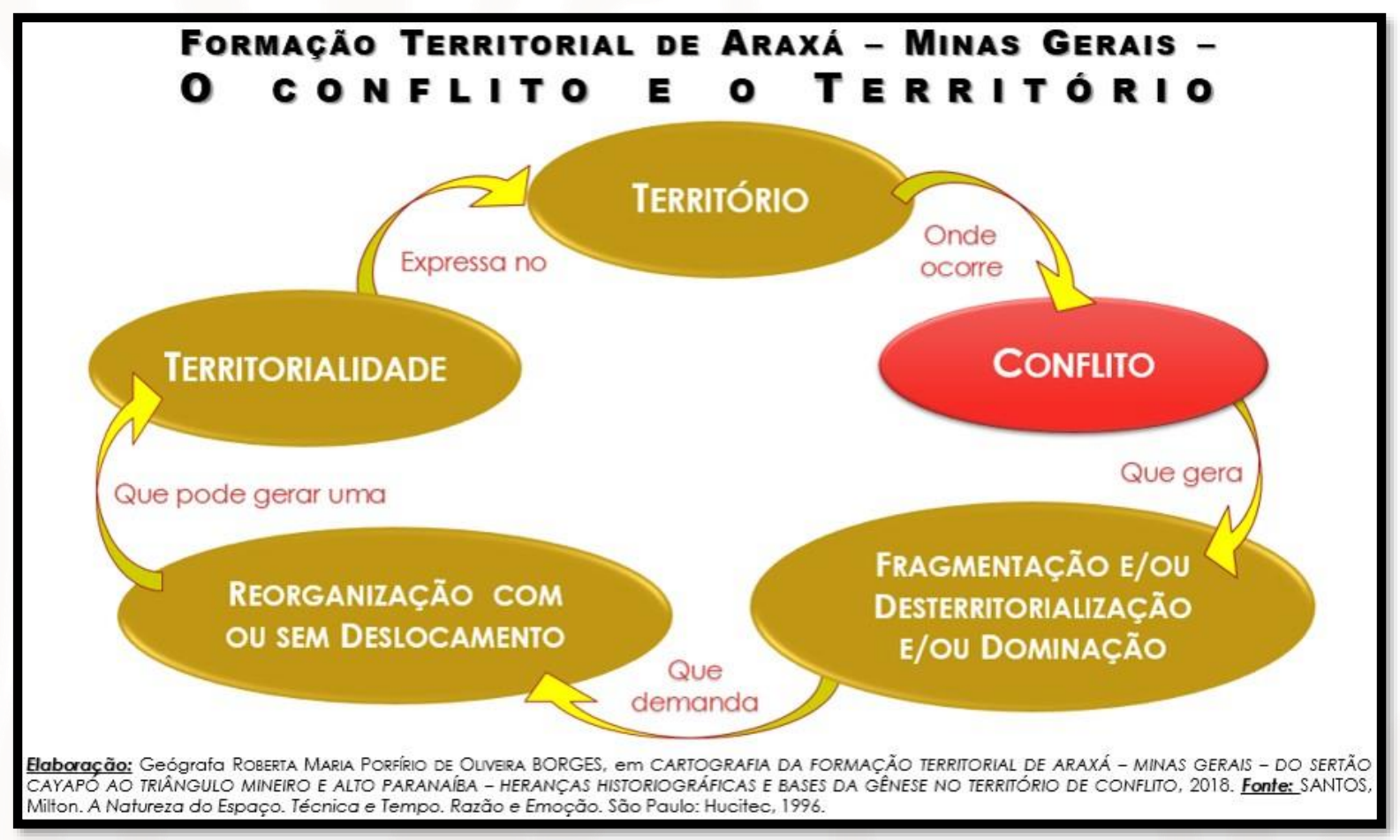

Figura 22 - O Conflito e o Território.

As Territorialidades Sobrepostas no contexto colonial são oriundas, basicamente, de três matrizes: Matriz Indígena, Matriz Africana e Matriz Europeia. Nesta pesquisa, em geral, são tratadas as Matrizes quando não for possível melhor especificação, no entanto, visto que destas matrizes inúmeros são os povos, culturas e territorialidades integrantes do processo aqui estudado, quando possível, ocorre foco em alguns não obstante a citação de outros, mas sem perder a visão dos papéis desempenhados, como um todo, na dinâmica do processo de Formação Territorial de Araxá.

A dinâmica territorial da Formação Territorial de Araxá, no período colonial, acontece como um ciclo de sobreposições de territorialidades que ocorrem:

- Sucessivamente no mesmo território;

- Em novos territórios;

BORGES, Roberta Maria Porfírio de Oliveira. 2018. 
- Diferentes no mesmo território, em união ou

- Diferentes no mesmo território em conflito.

Ciclo da Sobreposição das Territorialidades e a Dinâmica da Resistência ocorre da seguinte forma:

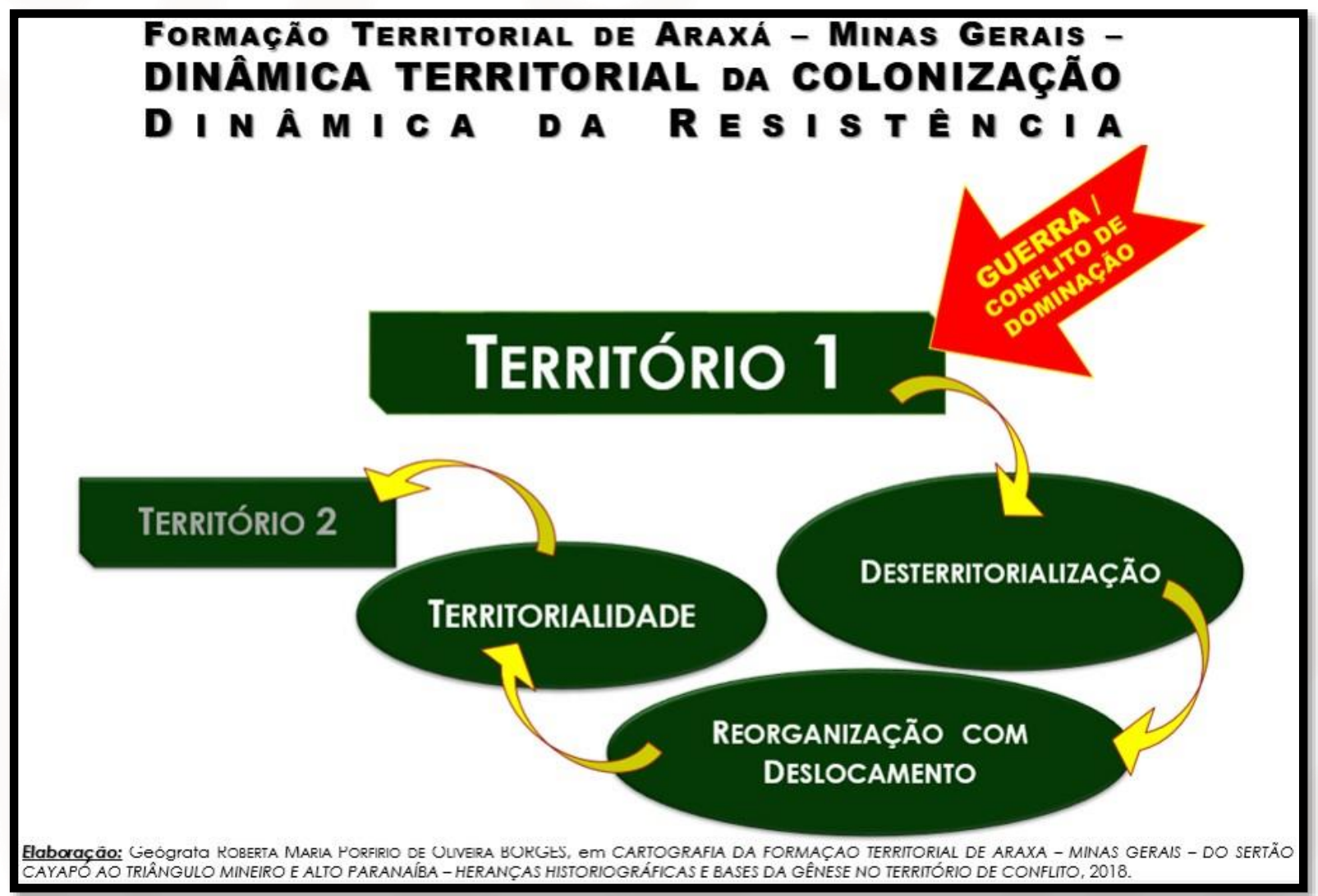

Figura 23 - Dinâmica Territorial da Colonização - Dinâmica da Resistência. 


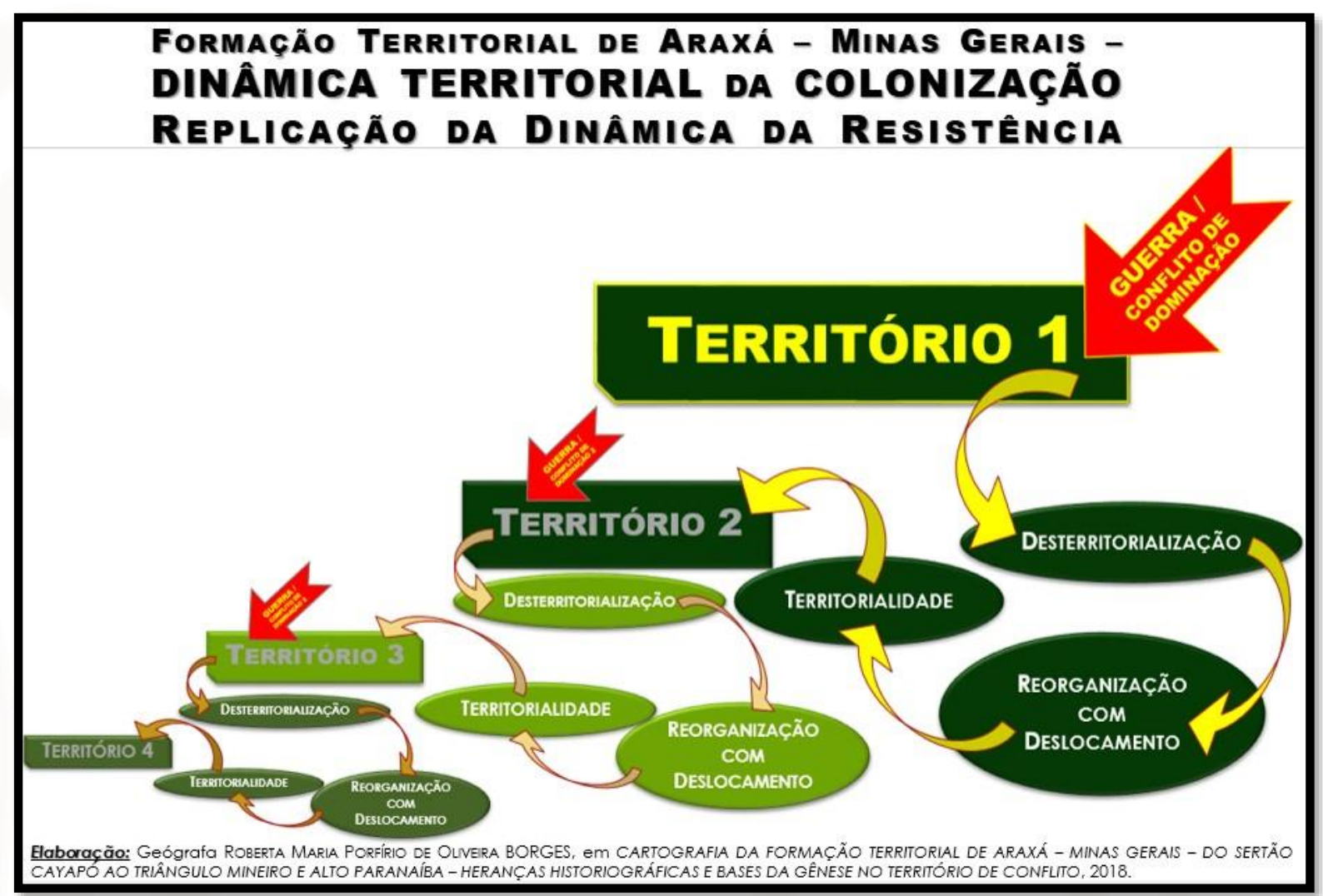

Figura 24 - Dinâmica Territorial da Colonização - Replicação da Dinâmica da Resistência.

O Território 1 existe, nele, está expressa uma territorialidade.

Considerando as demandas do sistema dominante que, em escala macro, rege a porção de terra em que está localizado o Território 1, chega ao Território 1 uma imposição de adequação aos interesses do sistema dominante. A necessidade de manter a integridade dos interesses locais gera conflito com a imposição de adequação aos interesses do sistema dominante. A resistência a servir aos interesses do sistema dominante gera a guerra.

Quando o sistema dominante é mais forte e vence a guerra, o que geralmente acontece, há a desterritorialização e a dominação, ou seja, aquele território passa a ser do sistema dominante e passa a servir aos interesses deste sistema em detrimento dos interesses do território dominado, a territorialidade que ali estava é destruída.

Se as pessoas ligadas à esta territorialidade destruída forem mantidas no território, elas serão parte de outra territorialidade, que expressa este sistema dominante e tudo o que o constitui. Estas pessoas se reorganizarão e poderão 
construir outra territorialidade própria, diferente da anterior, e que carregará as suas marcas e expressará a sua origem.

Se as pessoas forem expulsas do território ou forem obrigadas a deixa-lo para sobreviver, elas se reorganizarão e também poderão constituir outra territorialidade, diferente da anterior, que expressará a sua essência e a sua origem, mas em outro território, no Território 2.

A existência de um conflito em um Território, com uma territorialidade expressa, reinicia o ciclo. No contexto de colonização, este é um ciclo de expansão territorial, onde o conflito precede a colonização.

A replicação deste processo englobando a reorganização com deslocamento gera a dinâmica de sobreposição das territorialidades e a expansão, replicação e compartilhamento das territorialidades nos territórios onde elas se expressam.

\section{A Territorialidade da Matriz Indígena no Século XVI e as sobreposiçôes impostas}

\section{Representação da Territorialidade das Nações e Povos Indígenas no século XVI}

As nações indígenas referenciadas na fonte eram compostas de mais de um grupo e/ou etnia, predominantemente nômades, assim ocupando seus territórios de forma diferente das civilizações sedentárias, estas delimitadas em manchas urbanas e rurais que representamos por cor sólida ou padrão, enquanto aquelas possuem padrão de ocupação e delimitação baseados em referenciais que relativizam os limites de território. Buscando uma solução cartográfica capaz de expressar esta diferenciação e, especialmente, a heterogeneidade da configuração territorial das nações no século XVI, foi adotada a utilização de texturas para o preenchimento dos polígonos da espacialização destas nações indígenas no século XVI, visando além de um diferencial gráfico, a melhor adequação da representação à informação.

A cartografia representa parte da configuração territorial, visando contextualizar o processo estudado, portanto, não exaure as existências no território à época. O nível

BORGES, Roberta Maria Porfírio de Oliveira. 2018. 
de aprofundamento da representação é determinado pela viabilidade de dedicação ao mesmo dentro do trabalho, sendo assim, o possível para atender as demandas do objeto de estudo e limitado pela preservação do foco no objetivo da pesquisa.

O objetivo principal da representação de uma projeção da configuração espacial dos Povos e Nações de Matriz Indígena na Cartografia da Formação Territorial de Araxá é destacar que havia, de fato, uma Territorialidade da Matriz Indígena no território que seria colonizado pela Coroa Portuguesa, que o Tratado de Tordesilhas e o estabelecimento das Capitanias, Gobernaciones e das unidades administrativas subsequentes aconteceu sobrepondo uma organização territorial, uma territorialidade, na verdade várias territorialidades, de vários povos e nações que tinham seu próprio sistema de ocupação e sentido de pertencimento. A colônia não era apenas uma porção de terra abandonada a ser ocupada.

\section{De onde vêm as Sobreposições}

As sobreposições vêm do sistema dominante no determinado momento histórico, em cada território, em cada etapa e dimensão do processo de Formação Territorial. Cada imposição do sistema dominante é uma sobreposição, na medida que a imposição prevalece sobre o que já existia e estava previamente estruturado. Geralmente as sobreposições são iniciadas com uma Lei e, em caso de resistência, efetivadas por meio bélico.

Uma das dimensões da Formação Territorial é a construção ideológica, neste caso concreto, a construção vem do contexto global do expansionismo europeu que legou ao Território da Territorialidade das Nações Indígenas no século XVI o papel de Colônia no Sistema Colonial.

Já a estrutura judiciária, aqui é uma ferramenta de entendimento da instauração do poder central, nas localidades abordadas em diferentes escalas, revelando os vetores de expansão do sistema e permitindo a compreensão da dinâmica espacial desta esfera de dominação territorial.

Considerando cada Lei uma imposição que se sobrepõe ao Território e à Territorialidade existente, cada Lei é uma Sobreposição. Portanto o Ordenamento Legal e a Estrutura Judiciária vigentes no Sistema Colonial constituem uma rede de

BORGES, Roberta Maria Porfírio de Oliveira. 2018. 
imposições que, por meio da soberania da Coroa, sobrepõem no Território, a Territorialidade Colonial sobre a Territorialidade existente no Território.

Por meio da estrutura jurídica vigente à época, é possível entender parte importante da dinâmica de instauração, consolidação e desenvolvimento do sistema colonial no território brasileiro, estendendo a mesma lógica de compreensão ao território de Araxá.

\section{Estrutura Jurídica Portuguesa à época}

Os anos de 1500 a 1822 correspondem ao período historicamente denominado Brasil Colônia. Para compreender a estrutura judicial do Brasil Colônia é preciso conhecer um pouco da estrutura jurídica portuguesa da época. Cabia ao Rei a administração da justiça, sendo esta a sua primeira responsabilidade. O ordenamento e toda a estrutura jurídica portuguesa eram reunidos nas Ordenações. As Ordenações eram aplicadas à sede do império e às suas colônias. Devido às peculiaridades das colônias, muitas leis precisaram ser adaptadas. (CEZARIO 2010)

Além das Ordenações, também eram fontes normativas do judiciário da época o "Lex Romana Wisigothorum" - direito comum dos povos germânicos -, os Privilégios - direitos assegurados aos nobres pelos reis - e os Forais - leis particulares locais, asseguradas pelos reis. (CEZARIO 2010) 


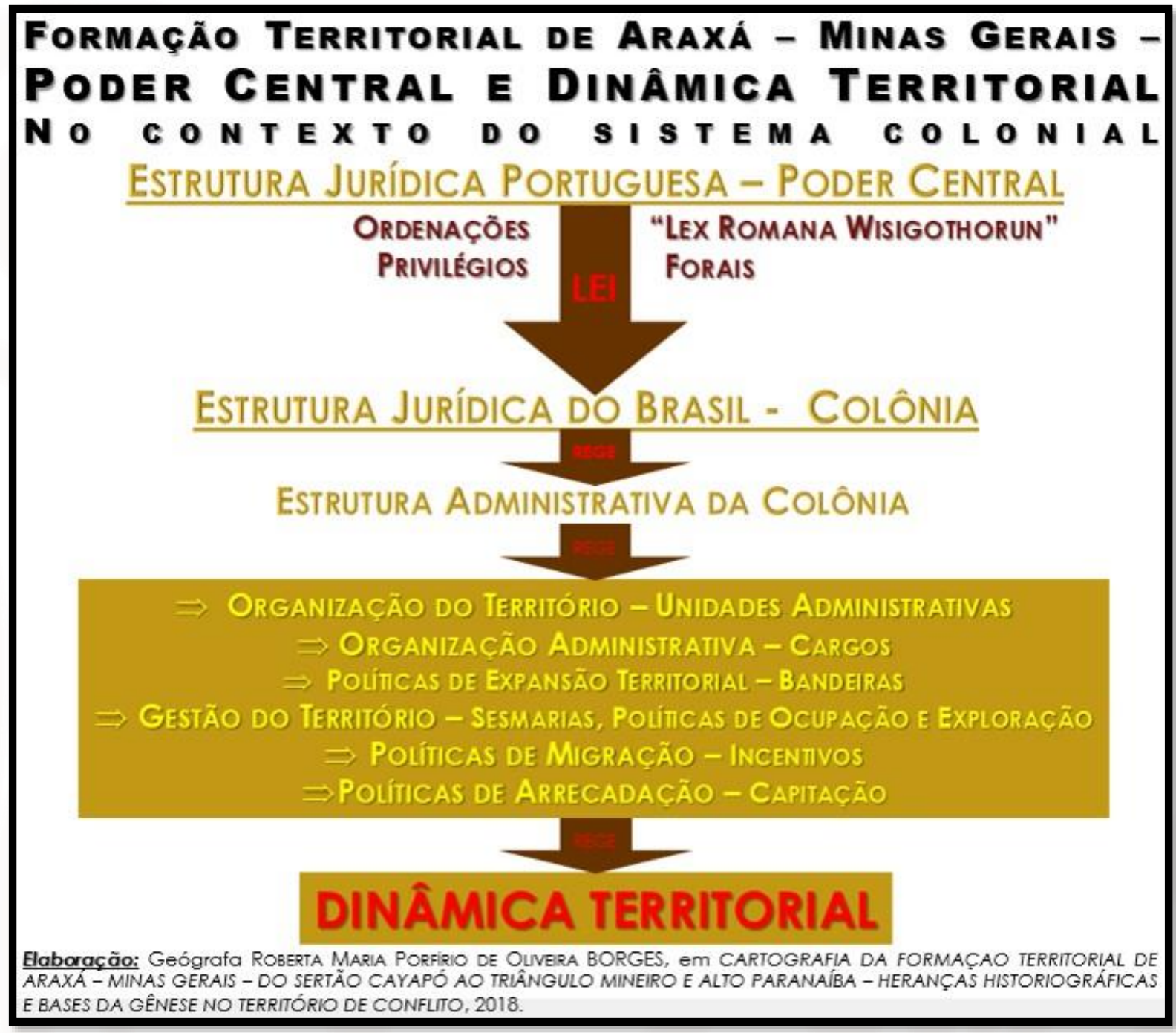

Figura 25 - Poder Central e Dinâmica Territorial no Contexto do Sistema Colonial.

Na Estrutura Jurídica do Império Português, a administração da justiça cabia ao rei, sendo considerada a justiça a primeira responsabilidade do rei em muitos documentos e leis. As Ordenações eram compilações que reuniam o ordenamento e toda a estrutura jurídica portuguesa. O rei D. João I, em seu reinado (1385-1521), elaborou e ordenou uma codificação, promulgada pelo rei Afonso $\mathrm{V}$ com o nome de Ordenações Afonsinas, tendo vigorado de 1446 a 1521, as demais Ordenações promulgadas - Ordenações Manoelinas em 1521 e Ordenações Filipinas 1605 - e o Código Sebastiânico em 1569, correspondem a revisões e recompilações de novas leis extravagantes. (CEZARIO 2010)

A importância de abordar o funcionamento das Ordenações é pertinente porque: 
"As Ordenações abrangiam juridicamente não só a sede do império, mas também suas colônias, porém, nem todas as leis eram de fácil aplicação no Brasil (assim como em outras colônias, onde muitas leis precisaram ser adaptadas), devido às peculiaridades culturais ou à falta de condições (de aplicação). " (CEZARIO 2010, grifo nosso)

\section{Estrutura Judicial e Administrativa do Brasil Colônia}

O início da colonização ocorreu em 1534, com a criação das Capitanias Hereditárias (1534-1536).

A Cartas de Doação, indicavam os limites e as léguas de cada território, Cartas Forais indicam o total de léguas conferidas ao donatário, sem especificar se o território é contínuo ou não; Alvarás de Lembrança são documentos de promessa de doação de terras; Apostilas são acréscimos, geralmente retificatórios, das Cartas de Doação dos Donatários; Carta de Mineração é um documento conjunto concedendo a exploração de ouro e prata aos três primeiros Donatários (Aires da Cunha, João de Barros e Fernando Álvares de Andrade), corrige ou acrescenta léguas, fornecendo os limites e as léguas atribuídas a esses capitães. (CINTRA 2013)

Algumas fontes fornecem documentos que para Cintra constituem os primeiros pilares do ordenamento jurídico brasileiro, a saber a obra de Maria José Chorão "pesquisadora que realizou a transcrição paleográfica, a apresentação e as notas aos documentos que se encontram na Torre do Tombo, em Lisboa". (CINTRA 2013)

"Alguns dados e textos provêm de outras fontes: as Cartas de doação de Martim Afonso de Sousa e de seu irmão procedem das obras clássicas de Pedro Taques ${ }^{9}$ e de Frei Gaspar ${ }^{10}$; a carta de mineração e a carta de doação a João de Barros estão transcritas, ainda que com pequenos erros ou lacunas, na introdução de António Baião à conhecida Ásia desse donatário que foi o cronista das Índias ${ }^{11}$ e também na clássica obra de Malheiro Dias ${ }^{12}$. Nos pontos cartográficos cruciais esses 
dados foram conferidos com os documentos originais, em pesquisa na Torre do Tombo." (CINTRA 2013)

Adotando como base a Cartografia das Capitanias Hereditárias de Cintra, em seu Novo Mapa das Capitanias Hereditárias 1534-1536 (CINTRA 2013), foi possível verificar que a Região de Araxá é transpassada pela divisão territorial derivada pelo Tratado de Tordesilhas.

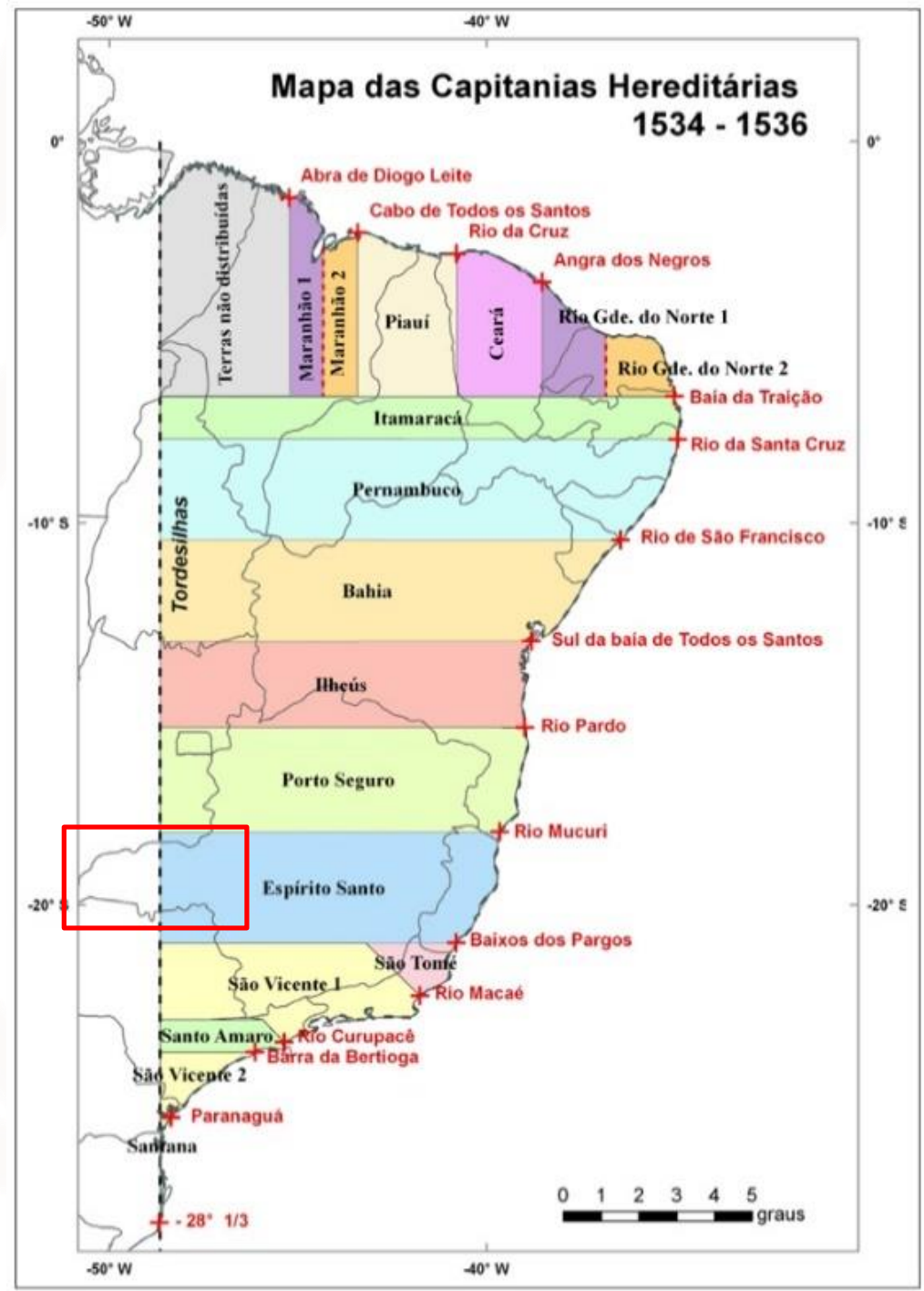

Figura 26 - Capitanias Hereditárias.

Fonte: CINTRA, 2013. Proposta do Novo Mapa das Capitanias Hereditárias. Com destaque da Região de Araxá.

Na Cartografia da Formação Territorial de Araxá - Minas Gerais - Brasil Principais Nações Indígenas na configuração Territorial do Século XVI, Tratado de Tordesilhas e Configuração Administrativa do Território em 1534 de acordo com as divisões realizadas pela Coroa Portuguesa e pela Coroa Espanhola a projeção dos 
limites aproximados das unidades territoriais foi feita a partir das delimitações das Capitanias Hereditárias dadas no Novo Mapa das Capitanias Hereditárias de Cintra, reproduzidas seguindo a metodologia dada em (CINTRA 2013, 37-38). Esta projeção das Capitanias foi feita sobre uma projeção da Configuração Territorial do Século XVI das Nações e Povos Indígenas.

Este primeiro mapa da Cartografia da Formação Territorial de Araxá, representa a primeira sobreposição que acontece de fora para dentro do território, do continente europeu sobre o continente sul-americano. Esta é a primeira escala de sobreposição, a partir do momento que estas linhas foram traçadas remotamente sobre o território, desencadearam um processo que passou, em vários ciclos, a se replicar em todas as escalas, transformando para sempre toda a configuração do continente. 


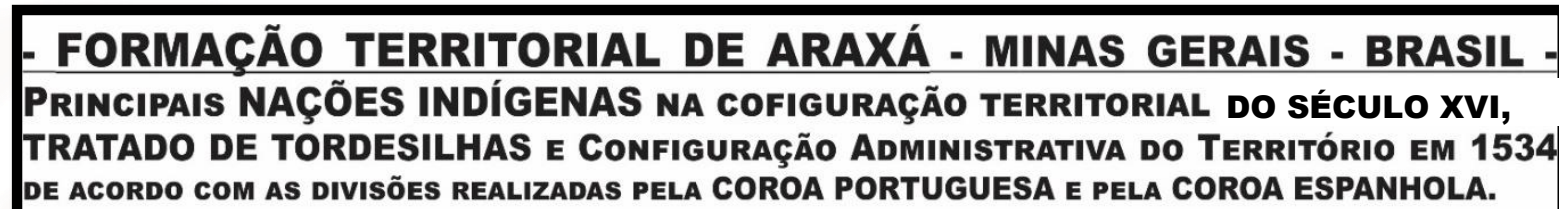
dE ACORdO COM AS divisões REALIZAdAS PELA COROA PORTUGUESA E PELA COROA ESPANHOLA.

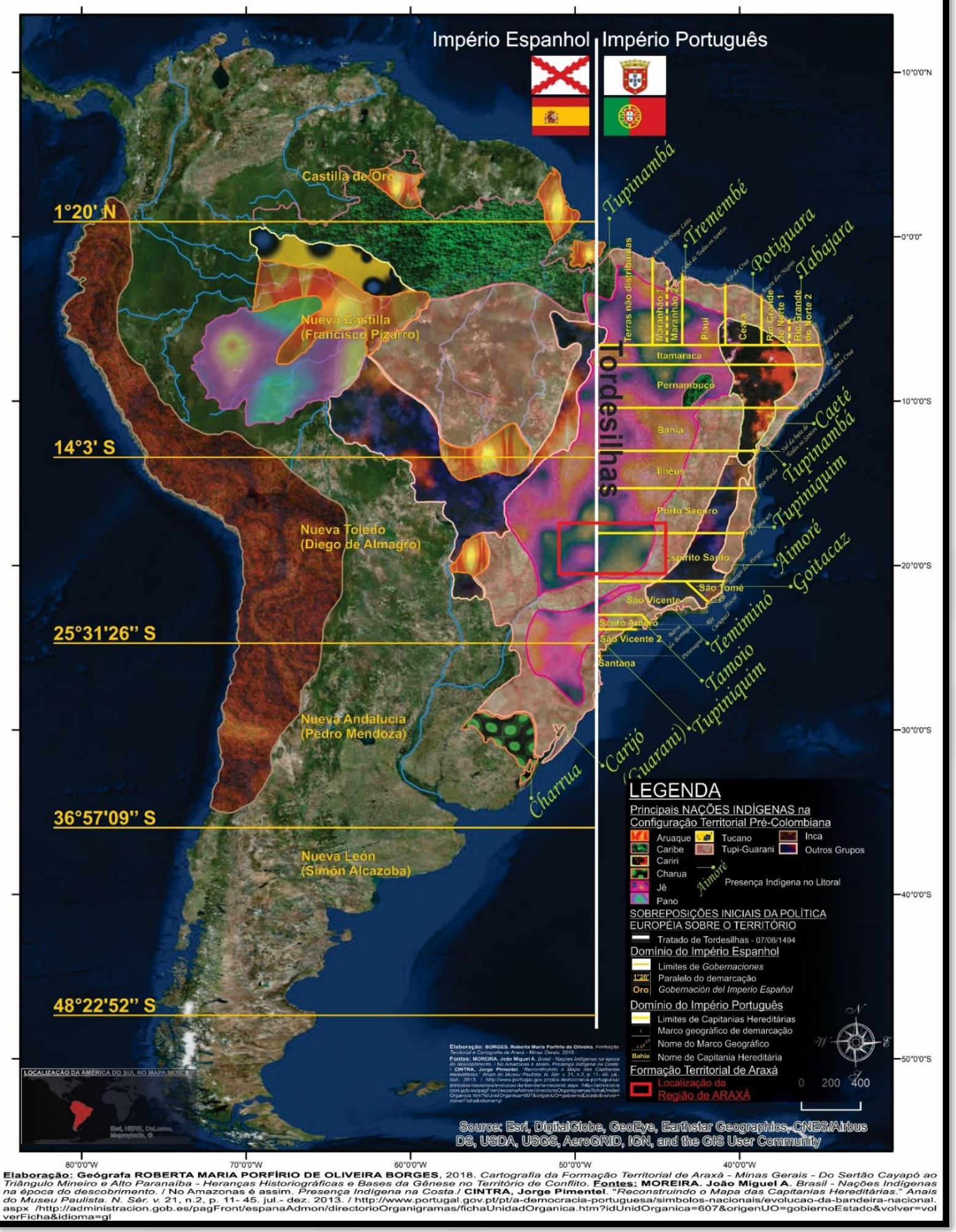

Figura 27 - Principais Nações Indígenas e Tratado de Tordesilhas. 


\section{A Colonização}

\section{Capitanias Reais}

O Regimento de 1548 substituiu a descentralização do sistema de capitanias hereditárias por uma centralização administrativa. As capitanias hereditárias continuaram existindo e as novas capitanias criadas a partir de então eram capitanias reais, administradas por alguém de confiança do Rei, por quatro anos, depois outra pessoa ocupava o cargo. (DIALÉTICO 2015)

Em 1549 houve a instalação do Governo-Geral por Tomé de Sousa e o início da estruturação do judiciário com o Desembargador Pero Borges desempenhando a função de administrador da Justiça no cargo de Ouvidor-Geral. Cada Capitania tinha um Ouvidor da Comarca. As questões jurídicas locais eram solucionadas nas vilas pelo Ouvidor da Comarca. (DIALÉTICO 2015)

Cargos inicialmente criados pelo governo português: Governador-Geral, auxiliado pelo Ouvidor-Mor, pelo Capitão-Mor e pelo Provedor-Mor. (DIALÉTICO 2015)

"As Vilas e Cidades da época eram governadas pelas Câmaras Municipais, ou Câmaras de Vereança, que possuíam funções mito amplas: administravam o patrimônio público, autorizavam a construção de obras públicas, cuidavam do policiamento, da nomeação de funcionários e do estabelecimento de impostos". (DIALÉTICO 2015)

Em várias ocasiões o governo português tentou restringir as atribuições das Câmaras Municipais, causando uma série de atritos. As Câmaras eram compostas por vereadores e juízes, escolhidos entre os "homens bons" do local, que eram os proprietários de terras pertencentes a elite da sociedade, e fiscalizados por "juízesde-fora", que vinham de Portugal. (DIALÉTICO 2015)

No Brasil Colonial, as funções judiciais confundiam-se com as funções administrativas e também com as funções policiais. Assim, devido à complexidade e especificidade das funções judiciais, haviam os Conselhos ou Câmaras Municipais,

BORGES, Roberta Maria Porfírio de Oliveira. 2018. 
formados por chanceleres, contadores e vereadores para a efetivação das atividades jurisdicionais nas comarcas. (CEZARIO 2010)

No entanto, as Comarcas correspondem aos limites territoriais da competência de um determinado juiz ou juizado, podendo coincidir com as delimitações administrativas ou não, sendo possível uma comarca englobar várias unidades administrativas, sendo uma a sede da comarca e os demais distritos da mesma, somente para fins de organização judiciária. (CEZARIO 2010)

Comarca é uma divisão territorial relacionada à organização judiciária. Comarca, "no brasil, é o termo jurídico que designa uma divisão territorial específica, que indica os limites territoriais da competência de um determinado juiz ou juízo de primeira instância. Assim, pode haver comarcas que coincidam com os limites de um município, ou que os ultrapasse, englobando vários pequenos municípios. Neste segundo caso, teremos um deles que será a sede da comarca, enquanto os outros serão distritos deste, somente para fins de organização judiciária. Comarca seria o lugar onde o juiz de primeiro grau tem competência, o lugar onde exerce sua jurisdição. (CEZARIO 2010)

\section{Colonização}

A colonização é um grande processo, "a colonização é em si mesma uma relação sociedade-espaço". (MORAES 2001, p.105)

"Colonização é a relação entre uma sociedade que se expande e os lugares onde ocorre essa expansão". "Colonização em si mesma é conquista territorial". A colonização "diz respeito a uma adição de território ao seu patrimônio territorial”. " Colônia pode ser entendida como a efetivação da conquista territorial". "A colônia é a internalização do agente externo". A colônia "implica a consolidação desse domínio territorial, a apropriação de terras, a submissão das populações defrontadas e também a exploração dos recursos presentes no território colonial”. Expressão que sintetiza tudo isso é a noção de conquista, que 
traz inclusive o traço de violência comum em todo processo colonial”. (MORAES 2001, p.105)

Moraes (2001) afirma que para entendermos o grande processo que é a Colonização temos que levar em consideração o que motiva a expansão da sociedade, no caso, de sociedades europeias e suas motivações próprias, também temos que considerar as geopolíticas metropolitanas específicas.

1ํ - O que motiva a Expansão de sociedades europeias:

- Carência de minerais;

- Carência de cereais;

- População disponível;

- Capitais disponíveis;

- Remuneração do capital mercantil.

\begin{tabular}{|c|c|c|c|}
\hline \multicolumn{4}{|c|}{ TIPOS DE COLONIZACÃO } \\
\hline $\begin{array}{c}\text { ESPANHOLA } \\
\text { (CASTILHA) }\end{array}$ & HoLANDESA & PoRTUGUESA & INGLESA \\
\hline Estatal & Privada & Mista & Diversificada \\
\hline
\end{tabular}

Tabela 1 - Tipos de Colonização

$2^{\circ}$ - Capacidade de adaptar as intenções geopolíticas à realidade defrontada.

- Quanto mais plástica a colonização, maior o êxito e a velocidade de instalação;

- As "populações locais são vistas como recursos naturais”. (MORAES 2001, p. 106, grifo nosso) 
No caso do território brasileiro, o colonizador teria que montar a colonização, investir, aplicar capitais, pois, em comparação à outras áreas da América:

- Baixa densidade demográfica;

- Não havia estrutura produtiva pronta;

- Não havia riqueza imediata para saquear;

- População nativa, nômade, dividida em muitas unidades políticas: mais de 1.400 tribos diferentes. (MORAES 2001, p.107)

Moares (2001) ainda explica que haviam geopolíticas metropolitanas específicas - motivações próprias. Cada Metrópole possuía suas próprias motivações para a colonização, esta diversidade de motivações gerou diferentes tipos de colonização:

- Metrópole Espanhola (Castilla):

- Colonização Estatal.

- Metrópole Holandesa:

- Colonização Privada.

- Metrópole Portuguesa:

○ Colonização Mista.

- Metrópole Inglesa:

Colonização Diversificada.

Moraes afirma que não existia Brasil antes do colonizador, que a única coisa que dava unidade a esse espaço era a colonização portuguesa, pois "não havia uma raiz indígena que amarrasse essa porção do espaço". (MORAES 2001, p.107)

Vetores da Conquista:

1ำ- Quadro demográfico 
$2^{\circ}-$ Recursos naturais

- "Onde há recursos naturais valiosos e não há população, a própria conquista envolve um empreendimento povoador; na maior parte dos casos, um povoamento forçado, seja por transferência de populações indígenas, seja por aquisição de escravos africanos". (MORAES 2001, p.107)

Motivações para colonização portuguesa:

- Descoberta das minas de Potosi no Peru;

- Esgotamento ecológico dos solos nos arquipélagos da Madeira e dos Açores.

Sistema Plantation de produção de açúcar trazido "pronto" das ilhas atlânticas com a transferência dos capitais ilhéus para o Brasil. (MORAES 2001, p.108)

Segundo Moraes (2001, p.112), o "século XVI não tem exclusivismo colonial”.

A 1aㅡ ocupação no Brasil envolveu dispêndio de capital - século XVI - A coroa tentou atrair particulares.

1570 - Grande século do açúcar no Brasil - vai gerar essa 1ª ocupação.

- Atividades subsidiárias à produção - primeiras atividades econômicas da colônia:

- Agricultura de abastecimento - nos solos inadequados para a cana;

- Pecuária - no sertão de fora;

- Madeira - construções, meios de transporte: carros de boi e barcos, combustível e caixas de exportação.

Neste contexto, aconteceu a chegada e a expansão jesuíta no território. Os Jesuítas se propagaram, se estabeleceram, se interiorizaram e transformaram os territórios por onde passaram.

A importância da chegada e a expansão Jesuíta neste processo de Formação Territorial pode ser expressa em alguns pontos principais: 
$1^{0}$ - A chegada dos Jesuítas representa a chegada de outro poder colonizador, além dos poderes da Coroa Espanhola e da Coroa Portuguesa, é introduzido e expandido o poder da lgreja propriamente dito, que, apesar de estar associado às duas Coroas Colonizadoras na expansão das respectivas soberanias, o poder da Igreja ganha configuração própria na expansão Jesuíta.

2ำ - A expansão Jesuíta constitui as Missiones, que são núcleos de catequização dos povos indígenas, "adequando" as pessoas de matriz indígena ao sistema de vida e produção missioneiro. No processo de colonização, os indígenas que mantém sua cultura, lutam pela sobrevivência do seu sistema de vida e fazem parte do movimento de resistência territorial e conflitos inerentes, são qualificados como índios selvagens. As Missiones ou Missões, aglomeravam em sua estrutura missioneira colonizadora pessoas de matriz indígena que, apesar de oriundas das comunidades tradicionais de matriz indígena da territorialidade original, já estavam mais integradas a uma territorialidade colonial, não mais fazendo parte da resistência ao sistema, assim, estas pessoas são qualificadas como "índios mansos", ou "índios domesticados", portanto, as Missiones eram aglomerações de "índios mansos". Desta forma, as Missiones Jesuítas são atrativas para as Bandeiras de Apresamento, ao oferecerem a oportunidade de apresamento sem ter que guerrear com os "índios selvagens", assim, os Bandeirantes as atacavam e apresavam os indígenas para obterem de forma mais fácil a mão-de-obra indígena.

3ํ- Estes ataques às Missiones constituíram vetor da expansão bandeirante na direção sul e sudoeste - Guayra - Tape.

4ํ- A Expansão Jesuíta promoveu uma das Fraturas da Soberania da Coroa Portuguesa com a criação da Província do Paraguay.

5ำ - A expansão Jesuíta também resultou na criação de Núcleos Urbanos importantes no território, como é o caso de São Paulo, fundado com a criação do Colégio Jesuíta e que anos depois converteu-se em principal polo de partida das bandeiras de apresamento que destruíram outros núcleos Jesuítas. Muitos outros núcleos urbanos foram fundados por Jesuítas e posteriormente convertidos em outras importâncias/ sistemas/ funções nos ciclos do processo de colonização do território. 


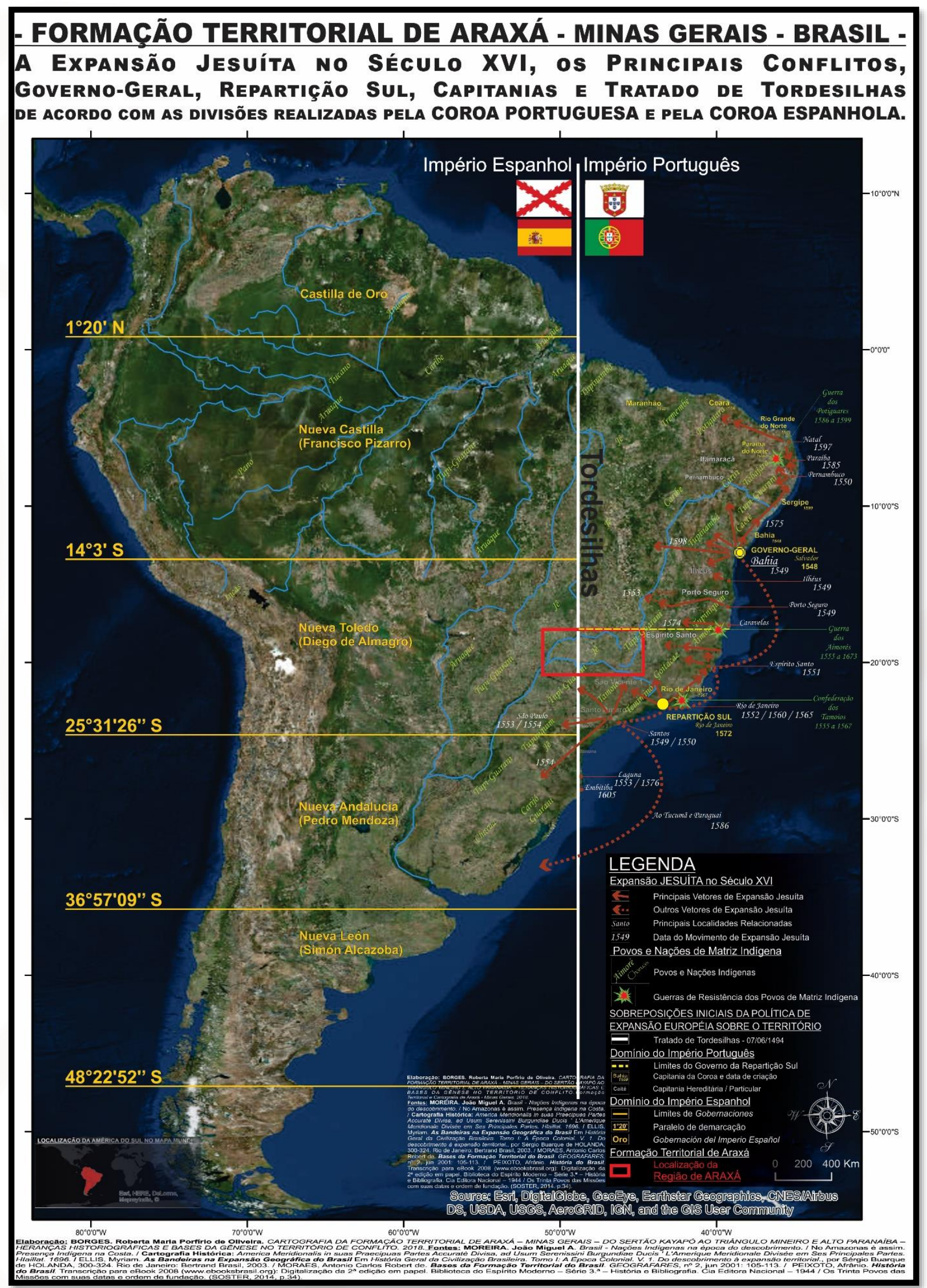

Figura 28 - Expansão Jesuíta no século XVI.

BORGES, Roberta Maria Porfírio de Oliveira. 2018. 


\title{
A Transformação das Fronteiras do Brasil
}

\author{
União Ibérica - 1580
}

\section{Grande expansão territorial:}

\section{Expansão para o norte}

Expansão de Pernambuco pelo litoral do Ceará até São Luís, para expulsar os franceses do Maranhão, fundação de Belém em 1616, foz do Amazonas - Província do Maranhão e do Grão-Pará, do império espanhol. (MORAES 2001, p.109)

\section{Expansão para oeste e para sul}

Expansão para oeste e para o sul em busca de índios para escravizar, para alimentar a indústria do açúcar. (MORAES 2001, p.109) - Bandeiras x Jesuítas.

O sétimo Governador do Brasil (1591-1602) esteve em São Paulo em 1599 e, segundo Ellis (2003):

"Convicto da ocorrência de riquezas minerais no interior do Brasil, fez partir de muitos pontos da colônia várias expedições pesquisadoras em demanda das pedras e metais preciosos. Com sua orientação, foram disciplinadas as expedições sertanistas, divisões militares, ouvidores do campo, escrivães, capelães e roteiros preestabelecidos". (ELLIS 2003, p.311)

As atividades destas expedições influenciaram fortemente na expansão paulista sertão a dentro, iniciando o século XVII, chamado o "Grande Século das Bandeiras", no qual predominaram as expedições apresadoras. A Vila de São Paulo converteu-se em uma "verdadeira forja de bandeiras" que adentraram o sertão em todas as direções e ultrapassaram o meridiano de Tordesilhas em suas expedições apresadoras. (ELLIS 2003, p.311-312)

Dentre as expedições do início do século estão a de André de Leão, até as nascentes do Rio São Francisco em 1601, a de Nicolau Barreto em 1602 e, em direção 
ao sul, as de Diogo de Quadros em 1606, a de Manuel Preto em 1606 e a de Belchior Dias Carneiro em 1607. (ELLIS 2003, p.311)

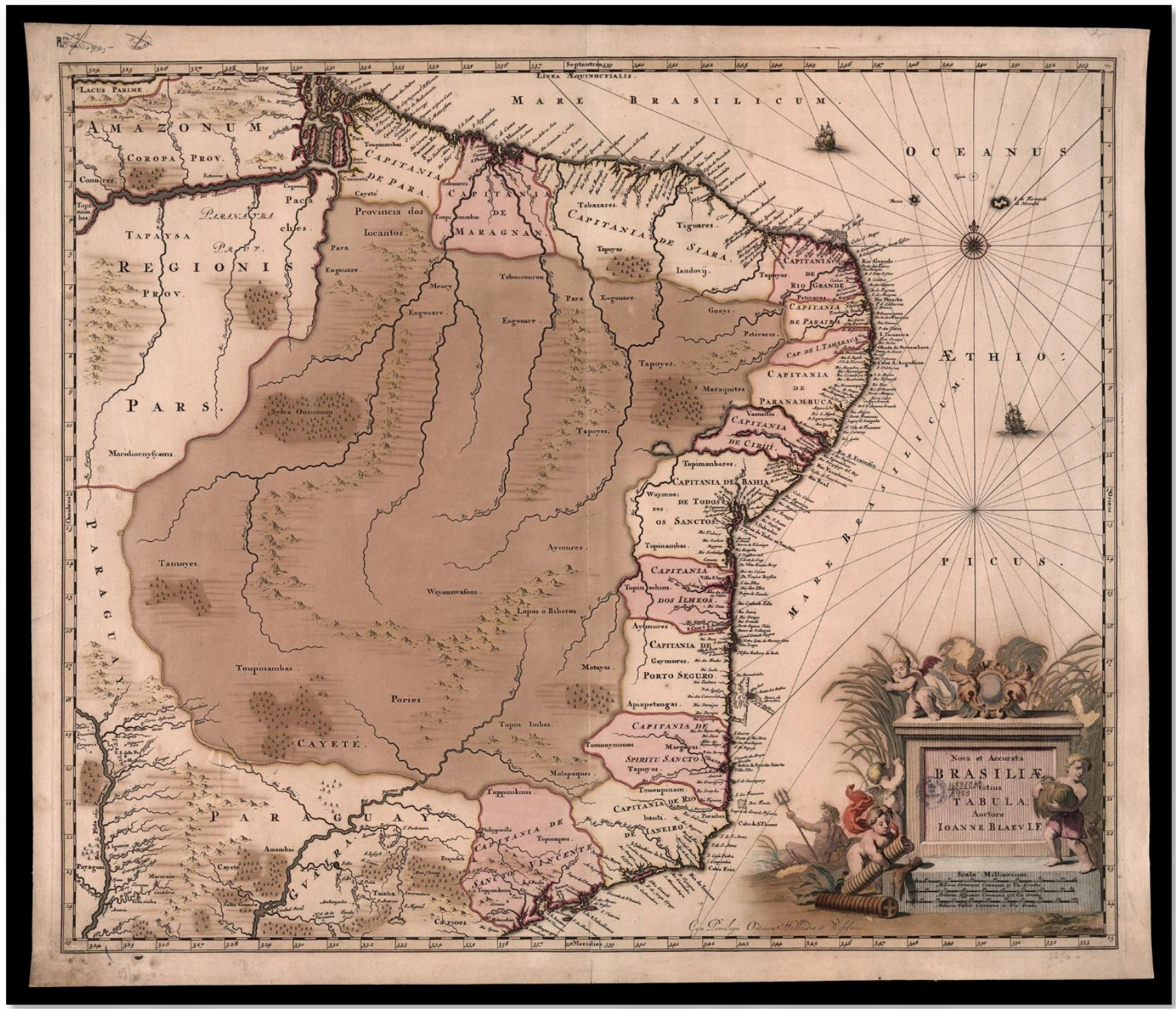

Figura 29 - Visualização do significado de Sertão na Cartografia Histórica: Nova et accurata Brasiliae totius tabula, 1689.

Permite a visualização do significado de SERTÃO no contexto colonial.

Toda a parte marrom no centro da área representada corresponderia ao Sertão, dentro deste Sertão haviam vários sertões, um deles, o Sertão do Gentio Cayapó. A medida que a colonização avança, os sertões vão mudando de toponímia, de acordo com o seu papel no grande sistema em que os territórios foram envolvidos. 
CARTOGRAFIA DA FORMAÇÃO TERRITORIAL DE ARAXÁ - MINAS GERAIS - DO SERTÃO KAYAPÓ AO TRIÂNGULO MINEIRO E ALTO PARANAÍBA - HERANÇAS HISTORIOGRÁFICAS E BASES DA GÊNESE NO TERRITÓRIO DE CONFLITO.

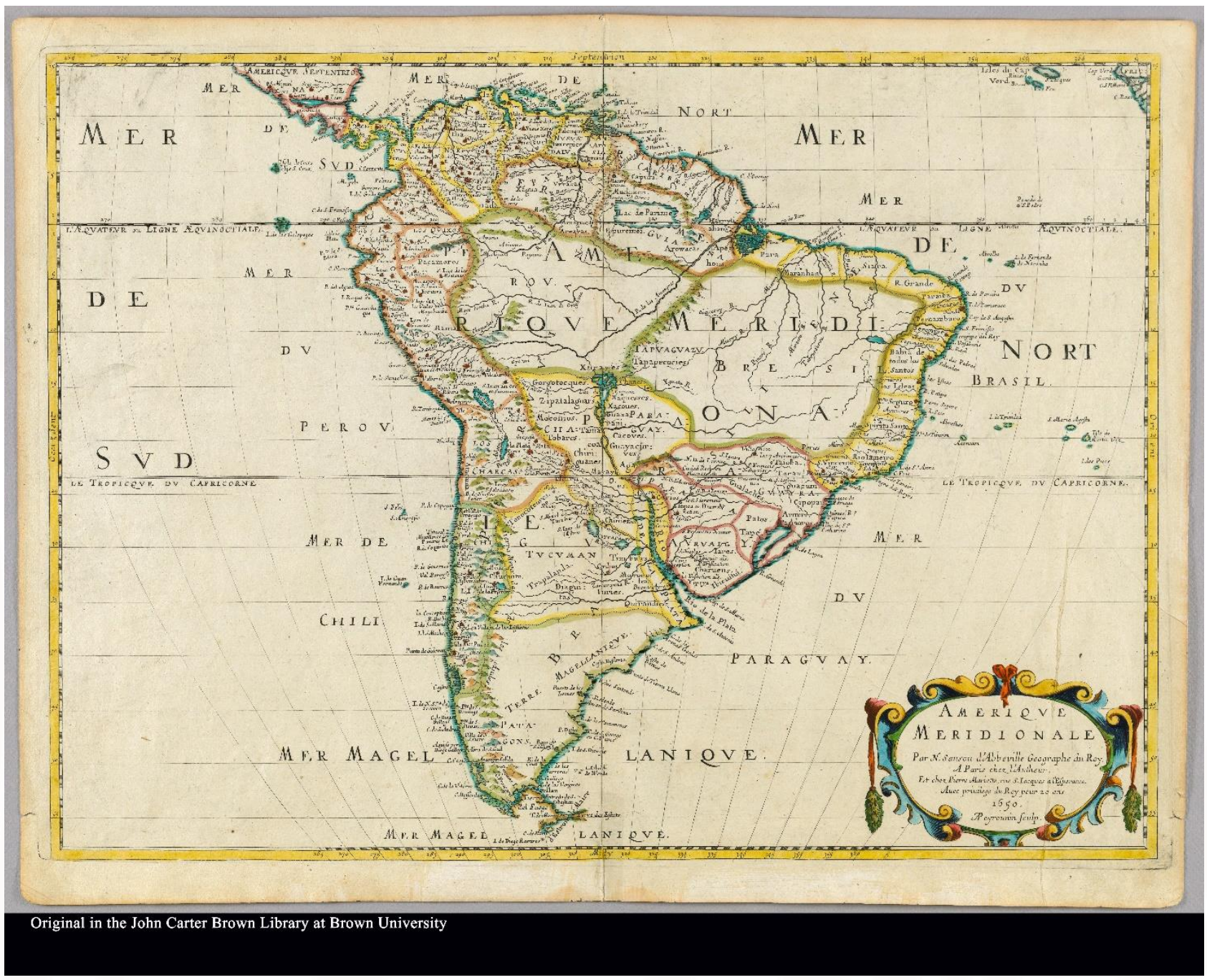

Figura 30 - Reflexão sobre a colonização do Território na Cartografia Histórica: Amerique Meridionale 1669.

Mostra além da configuração Administrativa, a ocupação do Território, com o interior do continente ocupado na região do Guaíra e todo o Paraguai, o Litoral das Capitanias e um imenso vazio no centro-oeste do território português. 


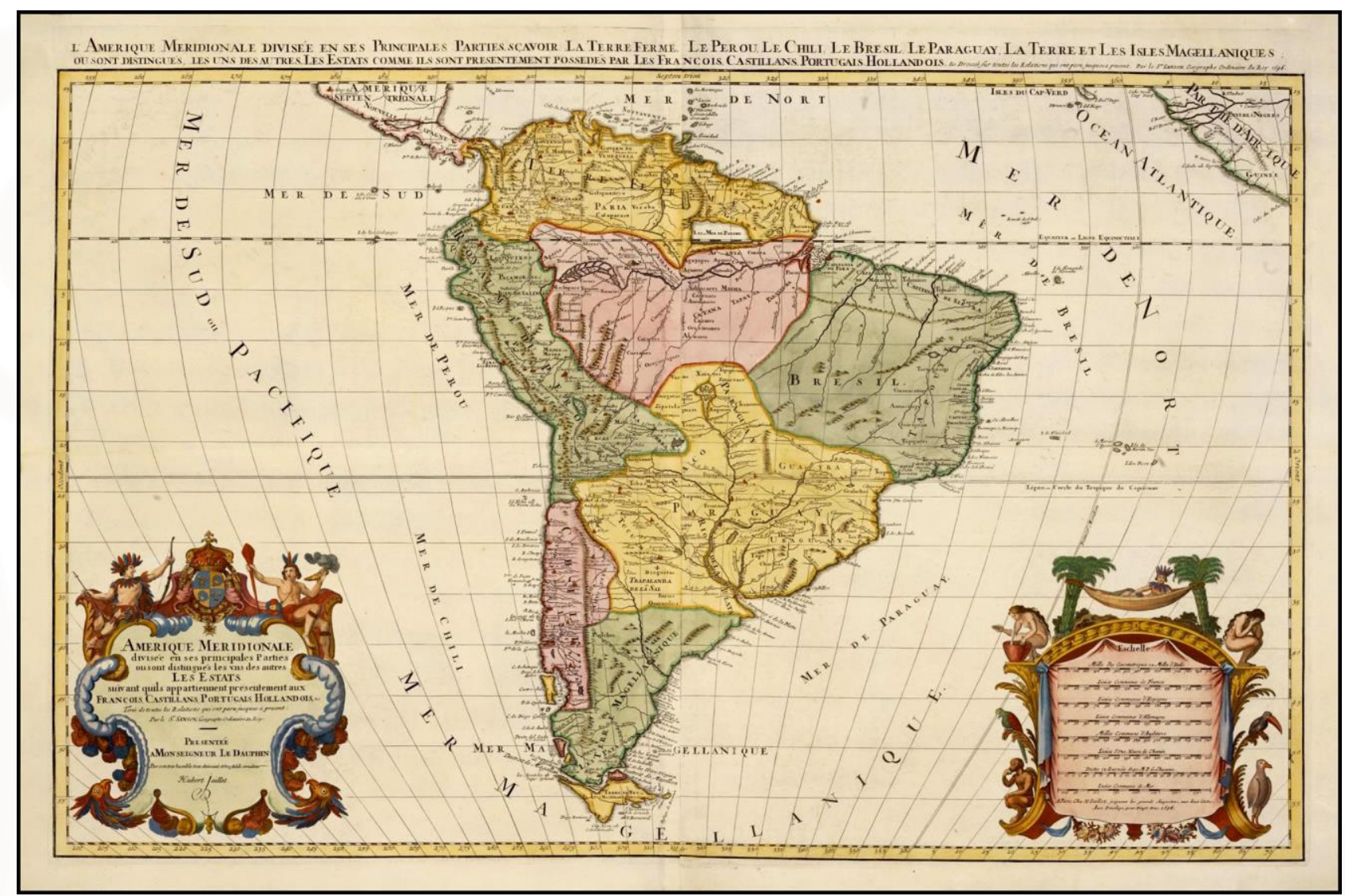

Figura 31 - Ilustração da Configuração Espacial na Cartografia Histórica: Amerique Meridionale 1696.

\section{Fraturas na soberania portuguesa sobre o território}

\section{brasileiro:}

\section{$1^{\circ}$ - Invasão holandesa}

Tomar a área produtora de açúcar, como elemento dentro da Guerra travada contra a Espanha na Europa pela independência holandesa da Espanha - Guerra dos 80 anos (1568-1648). Dominaram desde Maranhão à barranca do São Francisco, toda a Zona da Mata, auge da dominação na época da restauração da coroa portuguesa. Contexto da Guerra dos 80 anos (1568 - 1648) entre a Holanda e a Espanha. (MORAES 2001, p.110)

\section{$2^{\circ}$ - Quilombo de Palmares}

Auge em 1650 (70.000 habitantes - população semelhante à do Recôncavo Baiano, que na época, era a área mais povoada da colônia), durou quase cem anos, BORGES, Roberta Maria Porfírio de Oliveira. 2018. 
negociava com portugueses e holandeses, era um estado autônomo, uma situação de extraterritorialidade no domínio português, (MORAES 2001, p.110) na serra da Barriga, Capitania de Pernambuco, atual município de União dos Palmares em Alagoas.

\section{$3^{\circ}$ - Territórios dos Missioneiros}

Fruto da geopolítica do Vaticano, consistia na criação de um estado-tampão entre a colonização portuguesa e a colonização espanhola, objetivado pelas missões, que avançava pelo Orinoco, pelo Amazonas e pela bacia do Prata. Apesar da unificação das coroas ibéricas, o Vaticano não abandonou o plano, criando a Sagrada Congregação para Propaganda da Fé, para coordenar o trabalho das missões, respondendo diretamente ao Vaticano. (MORAES 2001, p.110)

\section{$4^{\circ}$ - Maranhão e Grão-Pará}

Não era o Brasil, era outra colônia, a Colônia do Maranhão, era província separada do Brasil, uma província do Império Espanhol que, sem passar por Portugal, se relacionava diretamente com o Conselho das Índias. (MORAES 2001, p.109-110) 

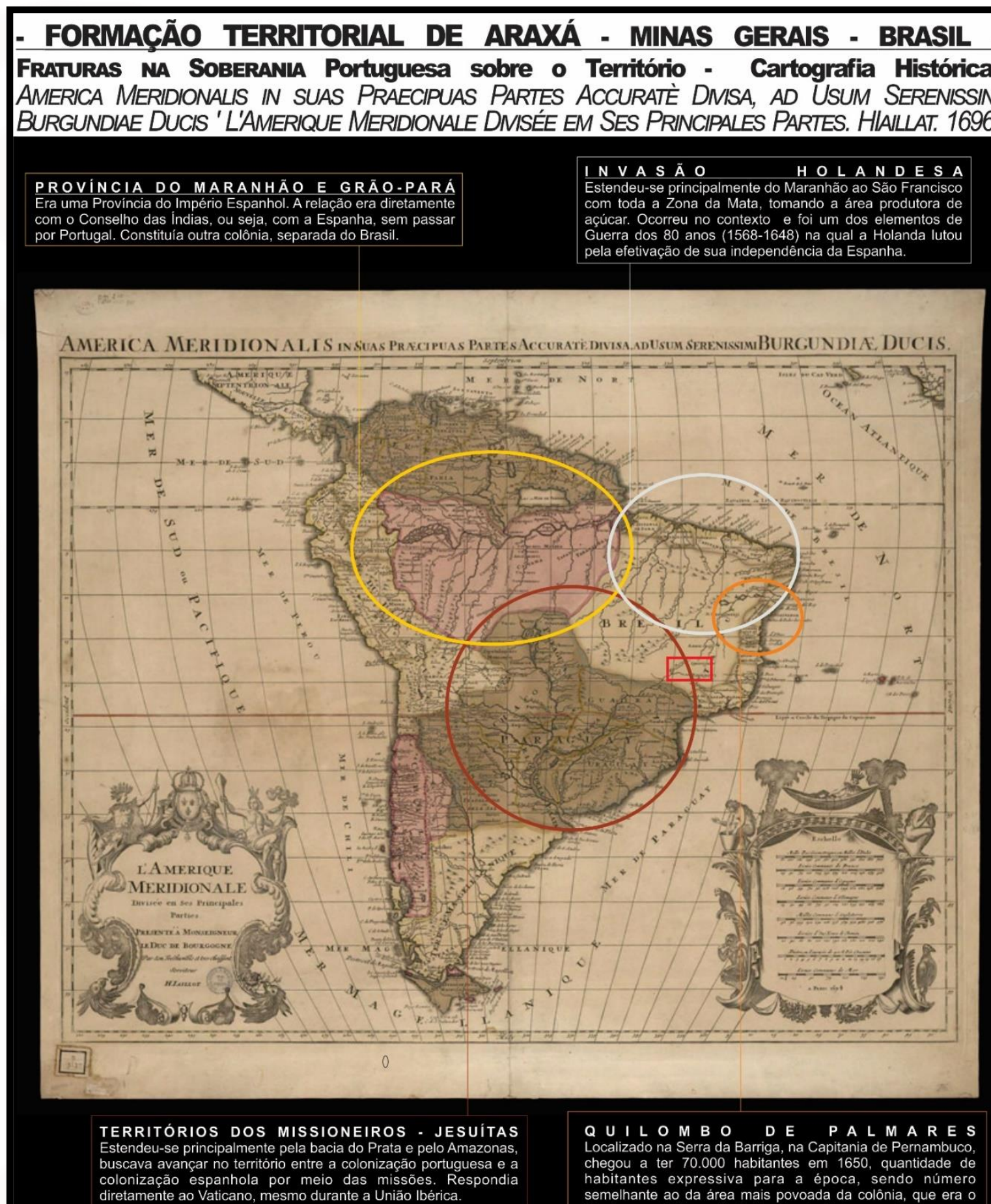

Q U I L O M B D D PALMARES Localizado na Serra da Barriga, na Capitania de Pernambuco, chegou a ter 70.000 habitantes em 1650, quantidade de habitantes expressiva para a época, sendo número semelhante ao da área mais povoada da colônia, que era o Recôncavo Baiano. O Quilombo de Palmares durou quase cem anos, negociando com Portugueses e Holandeses, funcionava como um estado autônomo, uma extraterritorialidade no domínio português.

\section{LEGENDA \\ Localização aproximada da Regiâo de ARAXÁ}

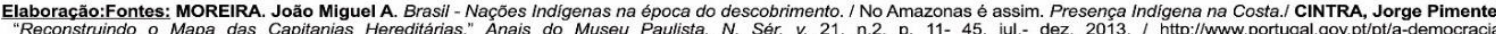
prtuguesa/simbolos-nacionais/evolucao-da-bandeira-nacional.aspx /http://administracion.gob.es/pag F/on/lessanad.

Figura 32 - Análise da Cartografia Histórica - Fraturas do Território em America Meridionalis in suas Praecipuas Partes Accuratè Divisa, ad Usum Serenissini Burgundiae Ducis ‘ L'Amerique Meridionale Divisée em Ses Principales Partes. Hlaillat. 1696.

BORGES, Roberta Maria Porfírio de Oliveira. 2018. 


\section{Restauração da coroa Portuguesa - 1640 \\ Processo de recuperação da soberania portuguesa sobre as terras da colônia brasileira:}

\section{Missões}

Ataques bandeirantes até o oeste do Rio Uruguai, saindo do território brasileiro, sendo restabelecida a soberania portuguesa neste território. (MORAES 2001, p.111)

\section{Expulsão dos Holandeses}

Processo de guerrilha, com queima de engenhos, de canaviais e inviabilização do embarque de açúcar em Recife. Sem lucro, os holandeses acabaram abandonando o Brasil, reestabelecendo a soberania portuguesa no Nordeste. (MORAES 2001, p.111)

\section{Destruição de Palmares}

Facilitada pela fixação territorial do quilombo e a chegada de uma estrada à capital palmarina, com tropas paulistas e artilharia pesada, foi reestabelecida a soberania portuguesa neste território. (MORAES 2001, p.111)

Expedições de extermínio de índios da caatinga, que eram acusados de serem pró-holandeses, abriam as terras para a pecuária e o avanço das boiadas formou a estrada chamada "Roteiro do Brasil", que ligava Salvador a São Luís. Este caminho terrestre foi utilizado para a fundação de Teresina e também garantiu a relação de Belém e do Maranhão com o restante do Brasil. (MORAES 2001, p.111)

\section{Os novos rumos do bandeirismo: A Procura de Riquezas Minerais}

No curso do Século das Bandeiras (século XVII), além da Conquista da Soberania da Coroa Portuguesa no Território na América do Sul, houveram outros eventos e consequências que impactaram a dinâmica territorial nesta colônia. 
A Restauração da Coroa Portuguesa tornou mais rígidas as fronteiras entre a América Espanhola e a América portuguesa, limitando a continuidade do alargamento do raio de ação das expedições bandeirantes. (ELLIS 20003, p. 314-315)

As missões localizadas ao alcance das bandeiras de apresamento foram abandonadas pelos jesuítas, restando a opção das incursões ao sertão bruto alémMantiqueira contra os índios selvagens. (ELLIS 2003, p. 315)

No Continente Africano, em 1648, houve a Reconquista da Angola, que, novamente sob o julgo da Metrópole lusitana, permitiu o abastecimento dos mercados negreiros do Brasil. (ELLIS 2003, p. 315)

Assim se dá o declínio do Bandeirismo de Apresamento, que, segundo Ellis (2003), deixou, dentre outras, as seguintes consequências:

- Fornecimento de braços para as lavouras piratininganas, na falta de escravos africanos;

- Devassamento do interior facilitando o povoamento;

- Recuo da expansão castelhana rumo ao Atlântico;

- E ainda:

"Conquista e o alargamento territorial do Brasil a sul e a sudoeste pela posse de extensa área correspondente à margem esquerda do Paraná e ao território do atual Estado do Rio Grande do Sul". (ELLIS 2003, p. 315)

O Bandeirismo de Apresamento passou a acontecer concomitantemente com o Bandeirismo Pesquisador de Riquezas. (ELLIS 2003, p. 315-316)

O Bandeirismo Pesquisador de Riquezas ou Expedições Pesquisadoras de Minerais Preciosos, ganhou força durante a grave crise econômica e financeira de Portugal, após a Restauração da Coroa Portuguesa, e o seu desencadeamento foi oficialmente estimulado:

"De caráter oficial e semi-oficial, foram essas entradas estimuladas por cartas régias enviadas pela Coroa portuguesa aos paulistas. Prometiam prêmios e honrarias aos sertanistas 
CARTOGRAFIA DA FORMAÇÃO TERRITORIAL DE ARAXÁ - MINAS GERAIS - DO SERTÃO KAYAPÓ AO TRIÂNGULO MINEIRO E ALTO PARANAÍBA - HERANÇAS HISTORIOGRÁFICAS E BASES DA GÊNESE NO TERRITÓRIO DE CONFLITO.

que descobrissem minerais preciosos, incentivando-os à aventura". (ELLIS 2003, p. 320) 
CARTOGRAFIA DA FORMAC̄̃O TERRITORIAL DE ARAXÁ - MINAS GERAIS - DO SERTÃO KAYAPÓ AO TRIÂNGULO MINEIRO E ALTO PARANAIIBA - HERANÇAS HISTORIOGRÁFICAS E BASES DA GÊNESE NO TERRITÓRIO DE CONFLITO.

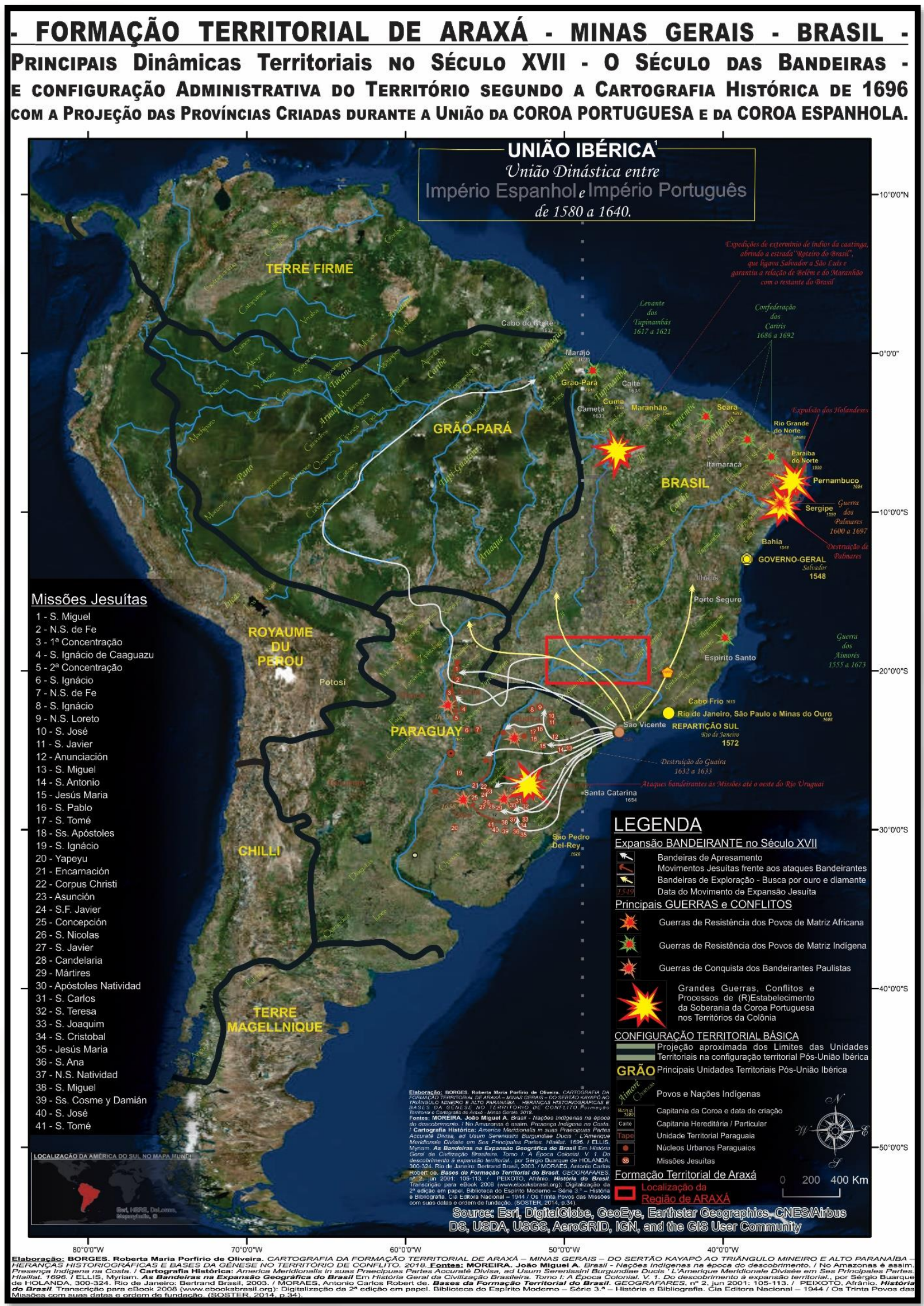

Figura 33 - O Século das Bandeiras.

BORGES, Roberta Maria Porfírio de Oliveira. 2018. 


\section{O Ouro}

\section{Final do Século XVII}

Deixando São Vicente para trás, saídos do planalto de Piratininga, homens como Jerônimo da Veiga, Sebastião Machado Fernandes Camacho e Fernão Dias Paes, ainda no século XVII, seguiram o Rio Paraíba e atravessaram a Mantiqueira pela garganta do Embaú em direção ao interior, no chamado "caminho geral do sertão". (PARANHOS 2005)

Aos poucos, surgiram às margens do Rio Paraíba, povoados, capelas e vilas como Taubaté, Guaratinguetá e Pindamonhangaba. Partiram da Vila de São Francisco das Chagas de Taubaté em direção às chamadas "minas dos cataguás", as primeiras bandeiras que alcançavam o atual território mineiro". (PARANHOS 2005)

A soberania portuguesa sobre o território brasileiro estava recomposta, definida, consolidada e em expansão, principalmente em direção ao interior, com a descoberta do ouro na última década do século, fenômeno que foi fundamental para o processo de formação territorial brasileiro. (MORAES 2001, p. 112)

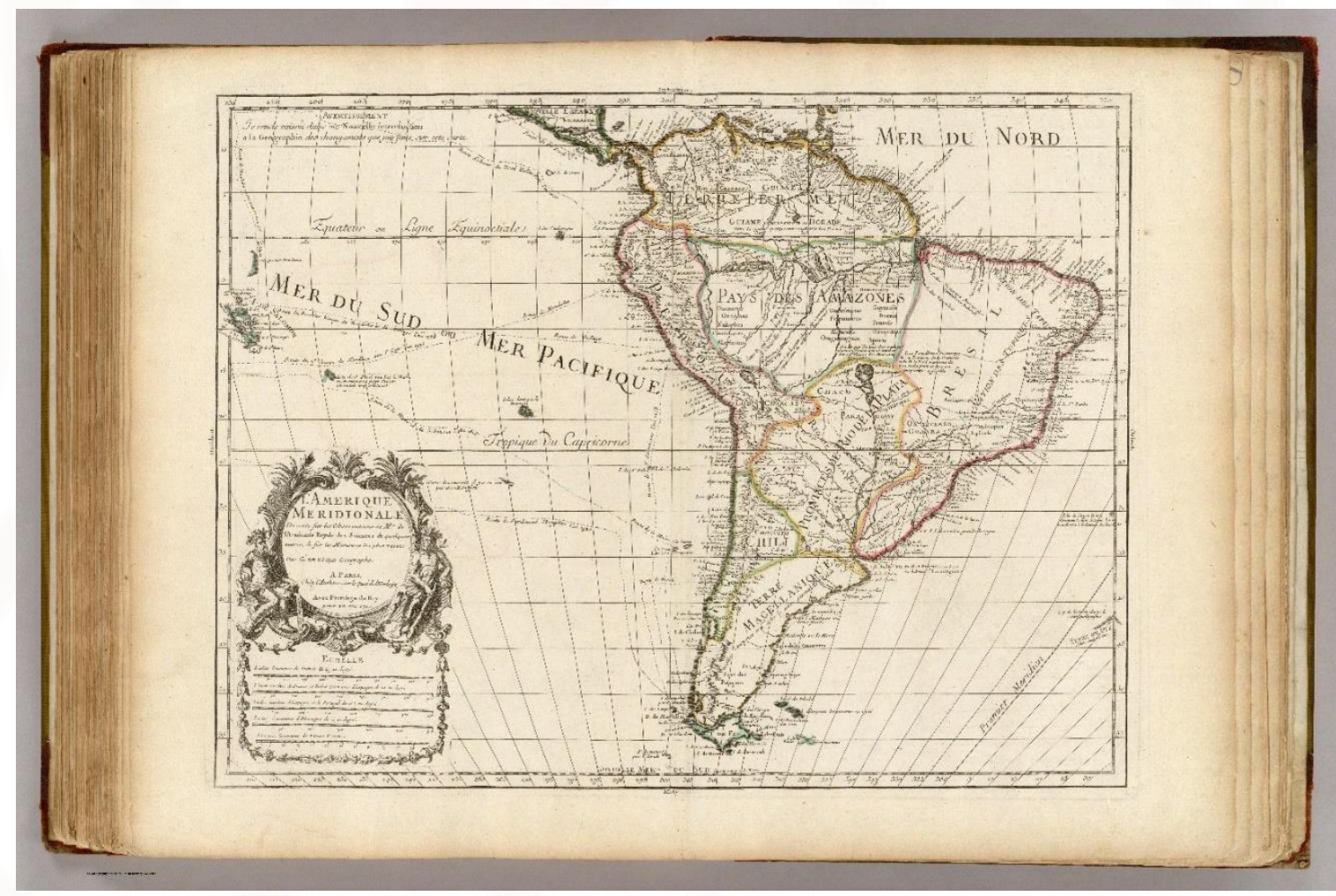

Figura 34 - Visualização da Configuração Territorial na Cartografia Histórica: L'Amerique Meridionale 1700. 
Martins (2008) descreve bem a dinâmica desencadeada pela descoberta do ouro:

"Os mineiros primitivos eram gentes de todas as etnias e de todas as castas que andavam de déu em déu em busca do ouro e do diamante. Ao grito de qualquer achado, acorriam em hordas, formando arraiais de cafuas feitas de capim, palha e casca de coqueiros. Logo, logo, apareciam as vendas e os padres; e, não demorava muito, aparecia também um oficial de elrei para fazer a "distribuição" das datas auríferas e organizar a arrecadação dos reais quintos. Arrecadados os primeiros impostos e comprovada a viabilidade econômica da aglomeração de gentes, instalava-se um pelourinho na praçazinha central, organizavam-se as viciadas eleições de pelouros constituindo uma câmara ou senado de homens-bons, composto geralmente de dois ou três vereadores e um juiz, e estava erigida ou ereta mais uma vila". (MARTINS 2008, p.99)

\section{A Igreja e os Núcleos Urbanos}

A Igreja e o Estado eram associados. A assistência religiosa aos fiéis era apenas uma parte da atuação da Igreja. A Igreja era o meio de obter vários serviços públicos essenciais como o de registros de nascimento e de casamento (MATINS 2008). A Igreja prestava serviços e possuía poderes muito além dos de ordem religiosa:

"A Igreja era associada ao Estado. Além da assistência religiosa aos fiéis, ela prestava diversos serviços públicos, destacando-se os serviços notariais, entre outros, sem os quais as pessoas não poderiam ter registro de nascimento (batistério), casamento etc. e nem mesmo poderiam ser enterradas pois, além dos registros, a Igreja controlava também os cemitérios. O seu relacionamento com os fiéis-vassalos era regido pelo código canônico, inclusive a nível do direito penal canônico, onde, de um lado, podia processar, julgar, condenar e mandar prender 
qualquer pessoa e, de outro, garantia foro privilegiado aos seus clérigos e padres em geral, cujas instâncias, na Colônia, ficavam a cargo do Bispado". (MARTINS 2008, p. 102, grifo nosso)

Barbo (2016) define Arraial como uma "espécie de povoação sem autonomia administrativa, submetida à tutela de uma Vila".

No processo de constituição de um Arraial, a Igreja também estava associada ao Estado, estando vinculada na dinâmica de expansão territorial da rede de Arraiais:

"Com a ereção da capela, o povoado, geralmente, passava a ser denominado arraial. A benção da capela implicava no reconhecimento da existência do povoado pelas autoridades religiosas. Sendo o catolicismo a religião oficial de Estado, os registros de batismo, casamento e óbito feitos pela Igreja é que davam legalidade aos indivíduos". (SOUZA JÚNIOR 2015 p. 106)

A legalidade dos indivíduos estava vinculada à Igreja, uma vez que somente a Igreja realizava os registros oficiais de batismo, casamento e óbito. Era possível fazer esses registros na freguesia mais próxima e legalizar o indivíduo, a família, mas no caso dos núcleos urbanos a legalização era mais complexa.

O reconhecimento da existência do povoado pelas autoridades religiosas se dava pela bênção à Capela.

"Cabe também enfatizar a importância da Igreja Católica na formação de arraiais e vilas no Brasil, posto que a sua presença era condição indispensável para a legitimação desses pequenos agrupamentos populacionais, haja vista que a data de concessão de cura da capela é, na maioria das vezes, considerada como data de fundação da localidade". (BESSA 2013, p. 514)

Ou seja, a oficialização de um Núcleo Urbano se dava pelo reconhecimento da presença da Igreja pelo Bispado. 
A presença da Igreja se dava mediante a construção de uma Capela, que, para ser realizada precisava de uma concessão, que seria um terreno, portanto, um patrimônio destinado à Capela.

Uma concessão dependia de uma Autoridade, portanto, dependia de um representante do poder da Coroa, dependia de legalidade.

Somente a presença da Igreja oficializava o Núcleo Urbano. Um Núcleo Urbano só era oficializado se houvesse legalidade, ou seja, se estivesse sob o poder da Coroa Portuguesa.

Bessa (2013 p. 514) ressalta ainda que a maioria das vezes a data de concessão de cura da Capela é considerada a data de fundação da localidade.

Com base em Barbo (2016), Souza Júnior (2015), Bessa (2013) e Martins (2008), sobre o processo de colonização, é possível estabelecer a seguinte dinâmica de criação dos núcleos urbanos no contexto do ciclo de mineração:

1ํ- - Bandeira:

Marca o território como uma Passagem;

$2^{\circ}-$ Ouro:

Marca o território com a existência de Ranchos.

3ำ - Capitão-Mor:

Marca o território com a presença de uma Autoridade (que representa a Coroa Portuguesa);

Cargo que podia ser concedido a um chefe de Bandeira, pela descoberta de ouro (como no caso de Bartolomeu Bueno, o Anhanguera filho);

Tinha o direito de distribuir Sesmarias e 
Tinha poder para organizar o espaço (que não deveria mais ser considerado um acampamento).

4ำ- Capela:

Erguida no centro de uma das concessões do Capitão-Mor,

É dedicada a um Santo (a).

5ㅇ- Igreja:

Com a bênção (concessão de Cura) da Capela, dedicada a um Santo (a), cujo nome passa a ser ou a fazer parte do nome do Arraial;

O Arraial é oficializado.

A partir da oficialização do Núcleo Urbano, a evolução administrativa não é mais vinculada à evolução da lgreja no local, podendo esta permanecer uma freguesia, sem tornar-se paróquia ou bispado, enquanto o Núcleo Urbano evolui de Arraial para Vila, Cidade, podendo ser, sede de Capitania, capital ou, nas unidades jurisdicionais, sede de Comarca ou Cabeça de Julgado.

"As vilas oficiais eram agrupadas em termos que, por sua vez, compunham comarcas em cujas sedes ficavam o ouvidor-geral, que era o magistrado maior, e os comandos das milícias pagas". (MARTINS 2008, p.101)

\section{Estas são as principais Unidades Territoriais na época do}

\section{ciclo minerador:}

\section{Eclesiásticas:}

Abrangem um território e tem uma sede. Todas as unidades eclesiásticas menores do território são subordinadas à unidade superior. Podem englobar territórios de várias unidades administrativas.

- Freguesia

- Paróquia

BORGES, Roberta Maria Porfírio de Oliveira. 2018. 
- Bispado

Judiciárias:

São áreas de Atuação de um Juiz. Possuem um núcleo urbano como sede. Podem coincidir com uma unidade administrativa ou não. Podem englobar várias unidades administrativas em uma unidade judiciária.

- Julgado

- Termo

- Comarca

Administrativas:

Relacionadas à administração de um território. Possui sede em um Núcleo Urbano.

- Capitania

Relacionadas ao nível de emancipação administrativa do Núcleo Urbano.

- Arraial

- Villa

- Cidade

Algumas outras denominações relacionadas ao processo de apropriação e colonização do território:

- Povoado

Núcleo Urbano sem capela, sem oficialização.

- Catas de Ouro/ Minas/ Achados

Núcleo minerador sem oficialização, sem capela.

- Passagem

Lugar conhecido, pode ser uma paragem ou lugar com alguma estrutura favorável.

BORGES, Roberta Maria Porfírio de Oliveira. 2018. 
Em geral, as mudanças administrativas criam uma nova unidade territorial, com uma fração da unidade territorial anterior, com uma nova representação do poder central, no caso, a Coroa Portuguesa, aproximando o poder central do território.

Esta aproximação se dá pelo aumento de representantes, visto que, na criação de uma nova unidade territorial desmembrada da anterior, o mesmo território passa a ter duas representações do poder central.

As mudanças administrativas com criação de novas unidades territoriais podem ser resultantes de um conflito local ou do poder central, mas sempre estão relacionadas à dinâmica territorial e à alteração do poder, como mecanismo que aproxima o controle ou a ação do sistema colonizador efetivando o poder no território.

Quando uma área fica, de alguma forma, alheia ao poder da representação central, outros poderes locais ou regionais emergem, se efetivam e se estabelecem. A Coroa Portuguesa já havia passado por esta experiência, há pouco havia estabelecido sua soberania sobre outros poderes que estavam no território. $\mathrm{Na}$ expansão européia, uma colônia é parte de um Reino, é território de uma Coroa soberana, o Rei é o senhor absoluto dos territórios conquistados.

\section{As promessas, o esforço, a conquista e o imposto}

Martins (2008) nos mostra que os paulistas bandeirantes haviam atendido aos estímulos da Coroa Portuguesa e se lançado à busca do ouro. Encontrado o ouro, e a mineração se consolidando, achou a Coroa que o domínio dos paulistas não estava garantindo a soberania portuguesa sobre os achados.

Então, por meio de Cartas Régias foi implementada uma política de migração que criou um grande fluxo de portugueses para a região das minas gerais. Assim, a Coroa Portuguesa estabeleceu uma legião de portugueses fiéis à Coroa, repletos de incentivos que, em pouco tempo, devido ao grande número, suprimiram a importância dos paulistas nas minas e até a forma de falar local, a língua geral, já estava suprimida pelo português da metrópole. (MARTINS 2008)

Evidente que o conflito latente eclodiu. Mas a situação criada era determinante, a legião de portugueses fiéis à Coroa havia sido estabelecida para garantir os 
interesses da metrópole nas minas, estava munida e fortalecida para isso. (MARTINS 2008)

Até na mão-de-obra a diferença entre paulistas e portugueses desfavorecia os paulistas que tinham quantidade já limitada de escravos indígenas apresados, enquanto os portugueses possuíam quantidade crescente de africanos escravizados trabalhando nas minas. (MARTINS 2008)

Esta diferença na quantidade limitada de escravos apresados dos paulistas e a quantidade crescente de escravos africanos dos portugueses tinha força e poder territorial, visto que, pelas leis de mineração vigentes:

"Cada escravo possuído dava ao dono o direito a duas braças e meia de terra". (MARTINS 2008, p. 28)

Logo a disputa culminou na Guerra dos Emboabas (1709). Com o evento conhecido como Capão da Traição a vitória portuguesa foi oficializada.

A consequência administrativa da Guerra dos Emboabas foi a criação da Capitania de São Paulo e Minas do Ouro, com foros de Capitania da Coroa. (MARTINS 2008, p. 37)

A criação da Capitania de São Paulo e Minas do Ouro trazia mais autoridades representantes da Coroa, para melhorar a gestão do território, mas o conflito criado seguia seu curso.

Difícil é mensurar exatamente as consequências que a forma de tributação pode trazer ao território. Uma mudança no sistema de tributação pode alterar completamente a dinâmica territorial tanto do território onde o imposto incide diretamente, quanto de outras localidades que podem, ou não, ter contiguidade territorial com a tributada.

Um exemplo foi o que aconteceu em 1719, quando por causa da tributação por meio do sistema de bateias (uma espécie de capitação), a Vila de Pitangui se esvaziara. O então governador da Capitania de São Paulo e Minas do Ouro a qual pertencia a referida Vila, reconhecendo a causa e a consequência, "prometera reduzir o imposto pela metade para que os mineradores voltassem". (MARTINS 2008, p. 71) 
No ano seguinte, na mesma Capitania, houve nova mudança no imposto com a implantação do Sistema de Tributação de Quintagem do ouro nas Casas de Fundição. A implantação deste sistema tributário gerou conflitos, culminando com o Levante de Vila Rica. Após o Levante de Vila Rica, em 1720 é criada a Capitania de Minas Gerais, com sede em Vila Rica e território desmembrado da Capitania de São Paulo e Minas do Ouro. (MARTINS 2008)

A Capitania de São Paulo e Minas do Ouro fica sem as Minas do Ouro não só no nome. A criação da Capitania de Minas Gerais desagrega do território paulista a região dos achados auríferos. O conflito continua latente e as disputas por territórios das fronteiras entre a Capitania de São Paulo e a Capitania de Minas Gerais ainda permanecem.

Nos embates entre portugueses e paulistas, a disponibilidade de grande quantidade de africanos e descendentes em diversas condições sociais, que foram armados para os combates, fez a diferença e foi decisiva na vitória dos portugueses. Assim, o domínio das minas foi passando para os portugueses, enquanto os paulistas iam perdendo os achados, sendo expulsos e excluídos das minas. (MARTINS 2008)

Os paulistas bandeirantes, eram expansionistas. As expedições feitas até então, na região entre os rios Tocantins, Araguaia e Paranaíba, exploraram mas não colonizaram Goiás. (BARBO 2016)

Segundo Mattos (2003), o que aconteceu com os paulistas nesse conflito com os portugueses nas Minas Gerais os incitou a procurar novos rumos para a expansão.

A expansão paulista, em alguns anos, revelou novos veios auríferos "em Cuiabá e em Goiás, incorporando essas extensas regiões do centro-oeste brasileiro à área de sua influência e garantindo, para Portugal, a posse definitiva de tão dilatados territórios". (MATTOS 2003, p. 334)

"Cabe comentar que a mineração não promove um povoamento com contiguidade territorial, ao contrário, gera um espaço intermediário entre os pontos de origem das correntes povoadoras e os núcleos mineradores, como salienta Prado Júnior (1986 apud BESSA 2013). 
Moraes (2001) afirma que o avanço da pecuária, até o Araguaia, Tocantins e também em direção ao sul do Brasil, se deu pela demanda mineira, voltada para o abastecimento da zona mineira, e que:

"A mineração foi também uma atividade essencialmente urbanizadora; em qualquer lugar onde ela ocorria criava cidades. Em consequência, gerou a primeira rede de cidades do Brasil. A produção aurífera gerou um setor dominante para a economia colonial brasileira. A partir dai a colônia, como um todo, trabalhou para a região mineradora". (MORAES 2001, p.112)

\section{Capitação}

Na década de 30 do século XVIII novas mudanças tributárias aconteceram. Em 1730, os interessados na mudança de sistema de tributação "já haviam obtido em segredo uma lista com o número de pretos forros que havia nas Minas", sendo que em "1730 e 1731 a alíquota dos "quintos" foi baixada para 12\%. Em 1732, votou a ser de 20\%”. (MARTINS 2008, p. 71)

Mas o sistema tributário instaurado em 1735, a Capitação, é que teve forte impacto na dinâmica territorial da Capitania de Minas Gerais.

Esta é também a época do Grande Arrocho Legislativo, que, na época branda, acontece da seguinte forma:

"Sobre os negros e pardos - livres, forros e escravos - indo desde a proibição de negras de tabuleiro venderem suas quitandas nas lavras diamantinas, proibição aos pretos do uso de armas, mesmo que fossem simples facas ou paus de ponta". (MARTINS 2008, p. 94)

O projeto do Sistema Tributário da Capitação foi concluído em 1734, com a tese de que a maioria dos negros e mulatos forros trabalhava em ofícios mecânicos, então, sendo estes também tributados e sendo recomendado ao governador que "não consentisse forros vadios e os obrigasse a servir na lavra das terras, ofícios mecânicos etc. de maneira a garantir a ampla base para o futuro tributo", "o custo do tributo a ser 
lançado sobre os escravos" seria pulverizado, a base tributária seria aumentada e geraria uma arrecadação maior para o Erário Régio. (MARTINS 2008, p. 71-72)

"Foi nesse governo que se estendeu o sistema tributário da capitação (por cabeça) para toda a capitania, incidindo sobre todo tipo de mineração, sobre todo tipo de trabalho produtivo. Cada senhor (fosse branco, pardo ou negro forros ou livres possuidores de escravos), pagaria o "quinto" pelo número de escravos que possuísse, empregasse-os ou não nas lavras. Já entre os brancos pobres, negros e pardos forros ou livres que trabalhassem com as próprias mãos, até as pretas tinham que pagar: prostituíam-se para conseguir os quintos de elrei!".(MARTINS 2008, p. 93, grifo nosso)

Martins (2008, p. 69; 72 e 93) afirma que "a tributação mais selvagem e cruel das Minas Gerais foi aquela que vigorou de 1735 a 1751, qual seja, o sistema por capitação", atribuindo ao Sistema de Capitação responsabilidade pela marginalização dos homens brancos pobres e pretos forros, identificando esta como a causa maior do fortalecimento e exacerbação dos quilombos nas Minas Gerais. Aponta ainda que não é coincidência a enorme quantidade de quilombos que surgem neste período, sendo grande parte "apenas vilarejos longínquos fundados por negros e pardos forros que queriam se ver livres, também, da capitação". (MARTINS 2008, p. 69; 72; 93)

"No entanto, houve povoados no governo de Gomes Freire que não aceitaram de maneira nenhuma a ingerência dos oficiais de el-rei. Isto, ou porque se tratavam de garimpeiros, ou por rebeldia ao poder colonial, principalmente na época do imposto da capitação". (MARTINS 2008, p.99) 
CARTOGRAFIA DA FORMAC̄̃̃ TERRITORIAL DE ARAXÁ - MINAS GERAIS - DO SERTÃO KAYAPÓ AO TRIÂNGULO MINEIRO E ALTO PARANAIIBA - HERANÇAS HISTORIOGRÁFICAS E BASES DA GÊNESE NO TERRITÓRIO DE CONFLITO.

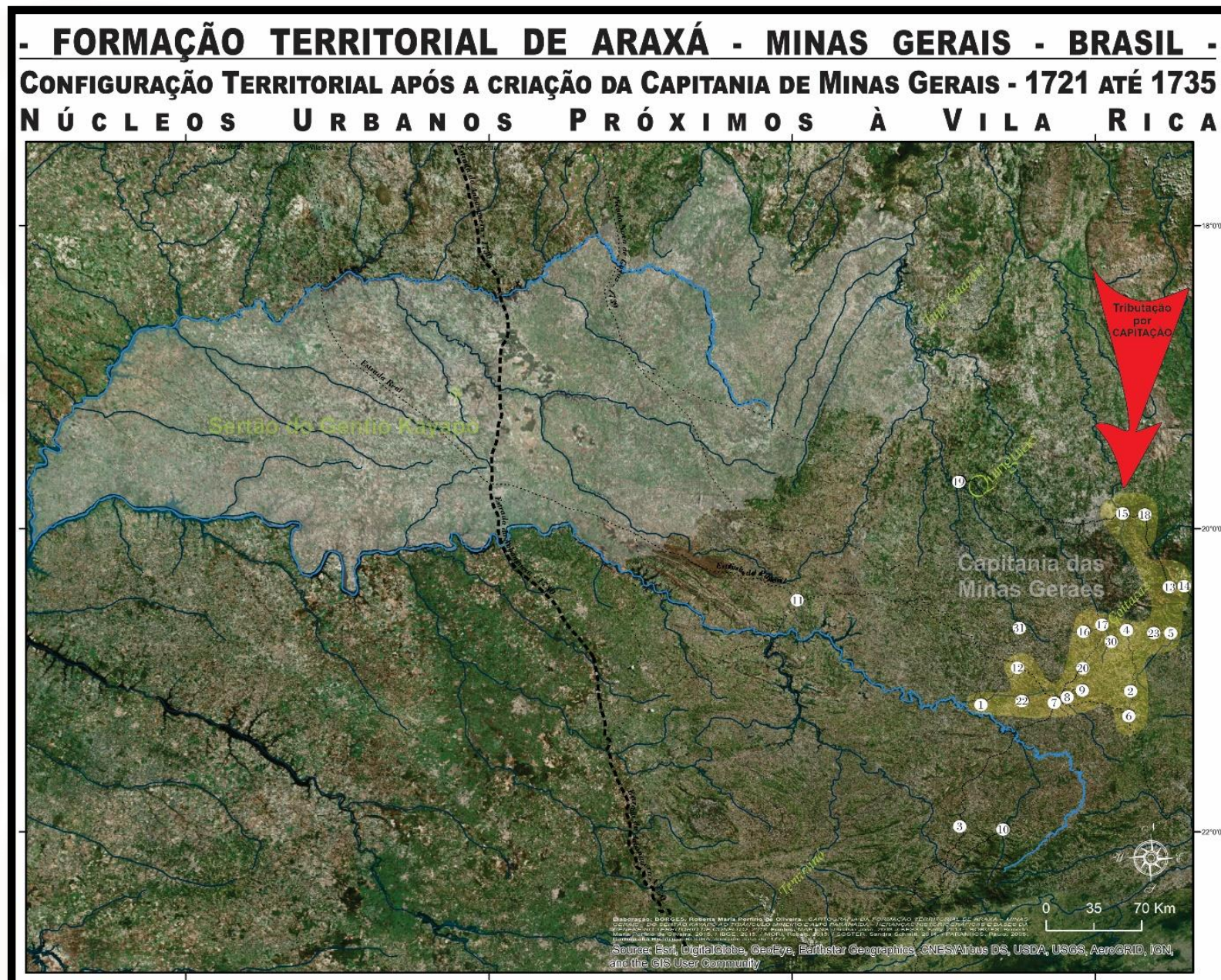

CONFIGURAÇ̃̃O TERRITORIAL E PRINCIPAIS CONFLITOS RELACIONADOS

Concentraçăo de Núcleos Urbanos Reconhecidos na Capitania de Minas Gerais.

Tributaçẫo por CAPITAÇĀO

A CAPTTACĂO foi um Sistema de Tributaçăo no qual todas as pessoas eram

Projeção de Territórios de NAÇÕES INDIGENAS segundo a Cartografia Histórica

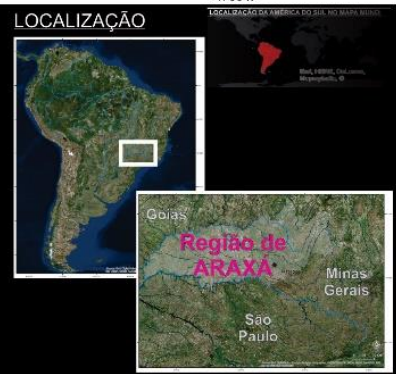

PRINCIPAIS NÚCLEOS URBANOS RELACIONADOS -

Povos e Naçôes Indigenas

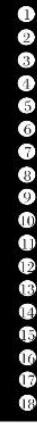

Ibituruna $1674-\mathrm{MC}$

Ressaca 1675 - Ressaquinha - MG

Baependi 1681 - MC

eiro Lafaiete - MG

Catsalas - Nontega 1690 - MC

São João Del Rey - MG

Prados 1704 - MG

Aiuruoca 1706 - MG

Fui 1707 - Piumhi - MC

Säo Tiago 1708 - MC

Vlia de Mariana 1711 - MC

Brumado 1713 - Entre Rios de Minas - MO

Suacui 1713 - Sắ Braz do Suacui - MG
Villa Nova da Rainha 1714 - Caeté- - MC

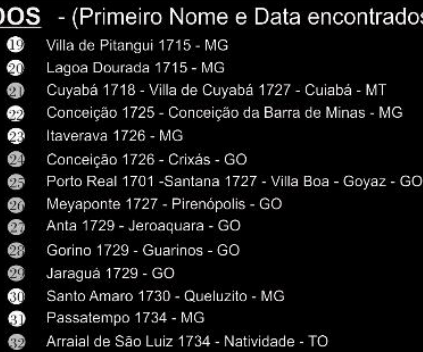

Arraial de São Luiz 1734 - Natividade - TO

TRANCAS HISTORIOGRAFICAS E BASES DA OENESE NO TET

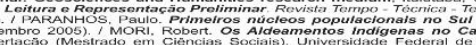

Figura 35 - Da criação da Capitania de Minas Gerais à Capitação.

BORGES, Roberta Maria Porfírio de Oliveira. 2018. 


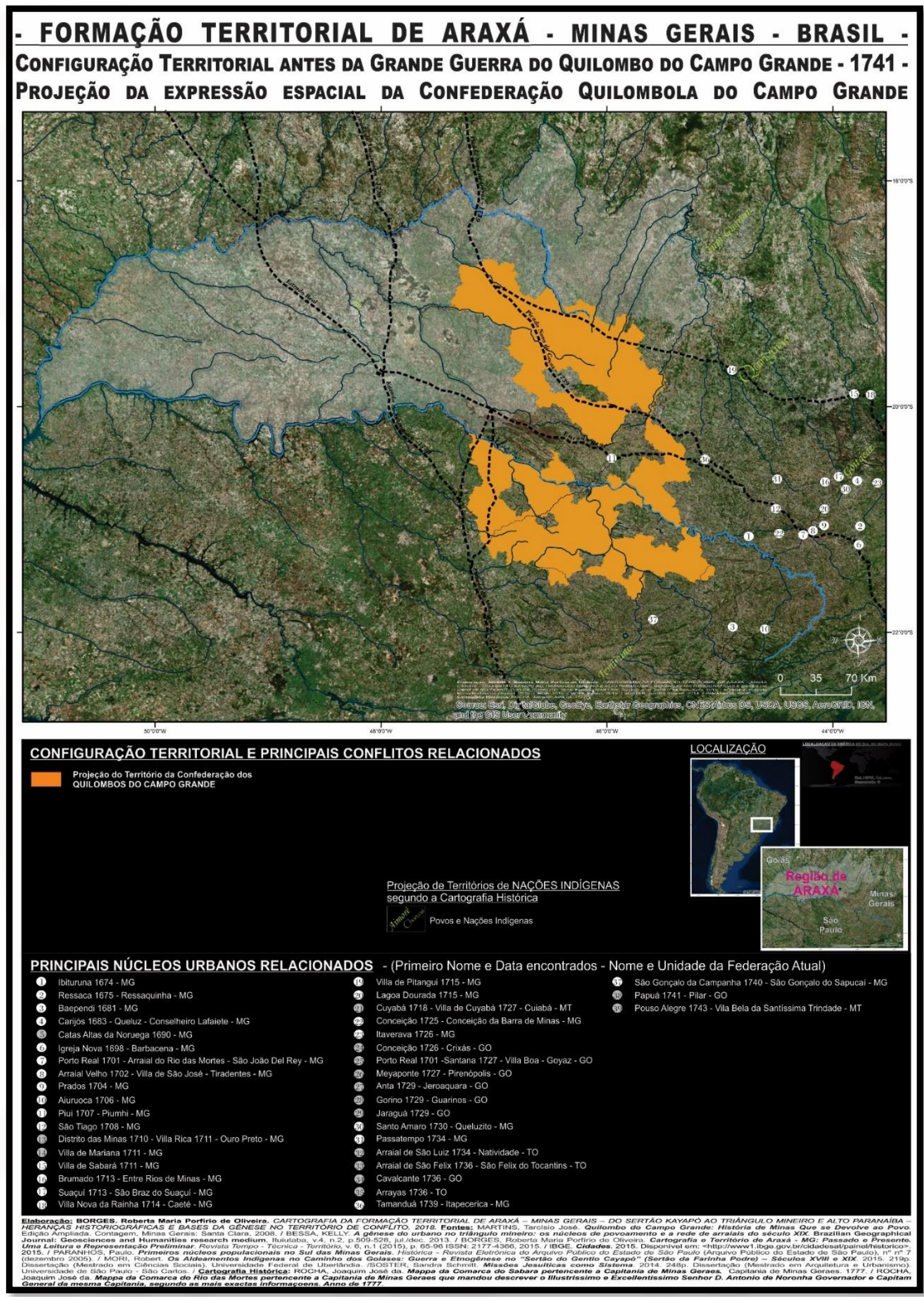

Figura 36 - Configuração Territorial pós-Capitação. 
No território de uma Colônia, o interesse que impera, que rege o sistema, é o da Coroa Portuguesa, a qual pertence o território da colônia. Neste contexto, as relações básicas de poder são claras.

Há os que estão posicionados de acordo ou em favor dos interesses da metrópole, enquanto ocupam esta posição/função, são preservados. O que estiver fora do sistema ou em posição conflitante com os interesses da metrópole serão diluídos, a estes, resta resistir, sobreviver e lutar para existir.

Claro que há meandros e a complexidade inerente às relações humanas na sociedade, mas, em linhas gerais, as relações de poder em uma colônia são relações de apropriação e dominação sobre o território e tudo o que estiver nele.

Marins (2008, p. 100) diz que "a maioria dos núcleos quilombolas do Campo Grande eram apenas povoados de pretos forros e gentalhas misturados ou não com fugitivos da escravidão" e ainda ressalta que na medida dos interesses do Governo, as povoações eram deixadas em paz.

"Revelando-se rica a região em ouro ou diamante, tais povoações eram simplesmente exterminadas por capitães-domato que, para isto, além da tomadia pelos negros fugidos que devolvessem aos senhores, recebiam de seis a mais oitavas de ouro por qualquer cabeça que apresentassem como supostamente de um preto quilombola. Destruídas as povoações, nada se perdia: além de se apossarem da liberdade e do sangue dos pretos - mesmo que fossem forros ou libertos - os assassinos se apossavam de seus achados, de suas mulheres e de suas crianças". (MARTINS 2008, p. 101)

Neste contexto, inicia-se a Grande Guerra do Quilombo do Campo Grande. 


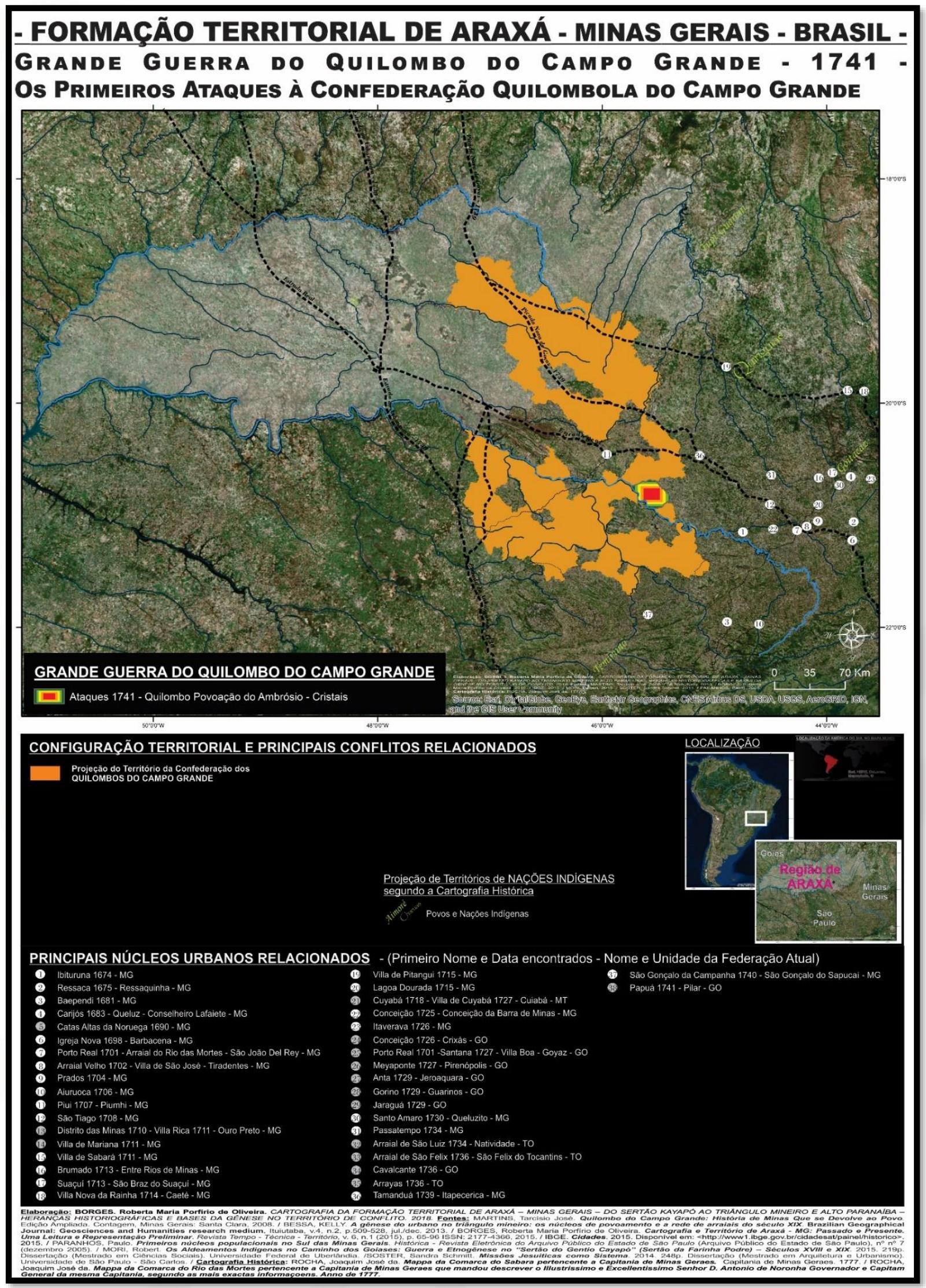

Figura 37 - Os Primeiros Ataques à Confederação Quilombola do Campo Grande - 1741. 


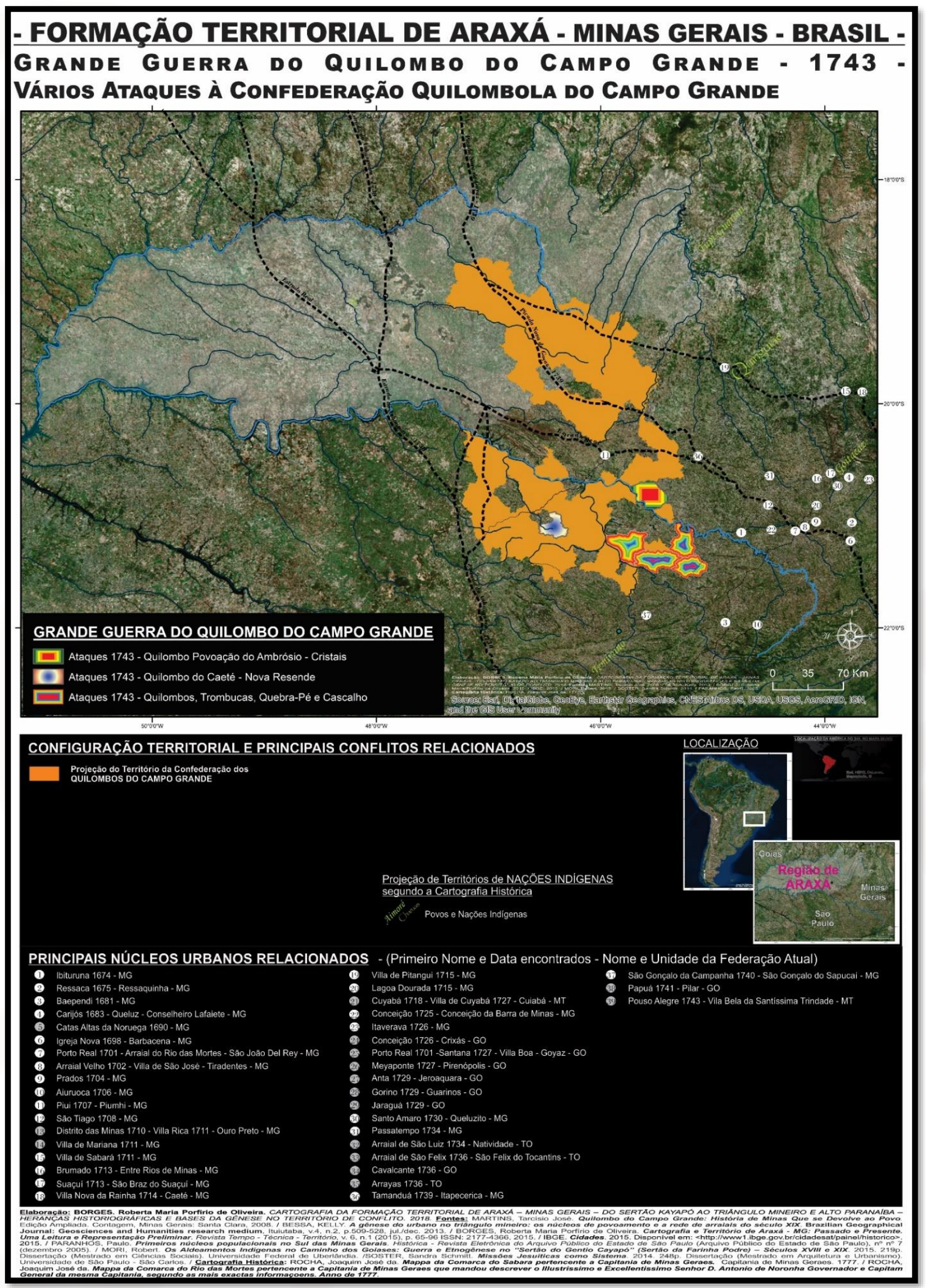

Figura 38 - Vários Ataques à Confederação Quilombola do Campo Grande 1743. 
CARTOGRAFIA DA FORMAC̄̃̃ TERRITORIAL DE ARAXÁ - MINAS GERAIS - DO SERTÃO KAYAPÓ AO TRIÂNGULO MINEIRO E ALTO PARANAÍBA - HERANÇAS HISTORIOGRÁFICAS E BASES DA GÊNESE NO TERRITÓRIO DE CONFLITO.

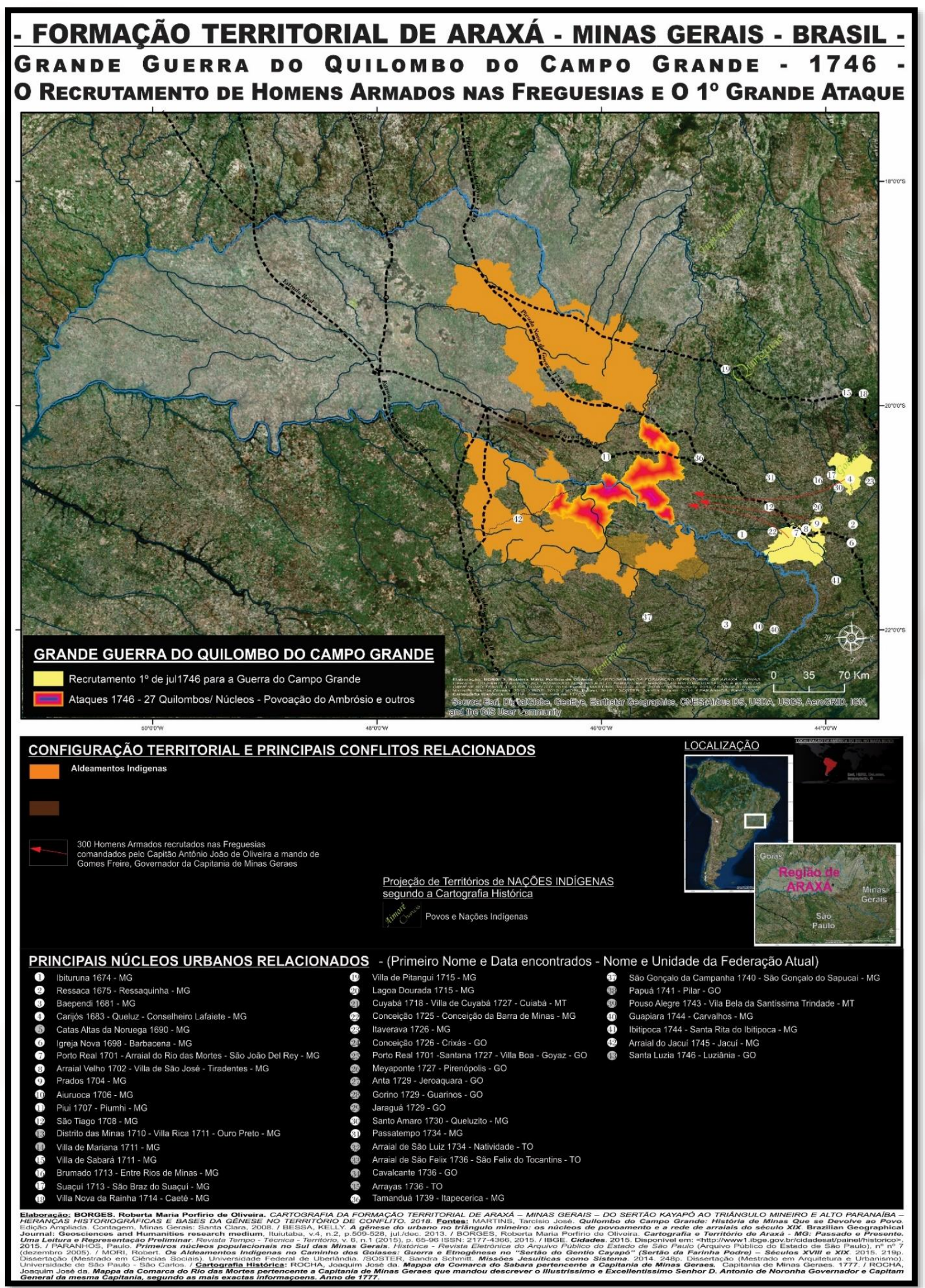

Figura 39 - Grande Ataque - 1746. 


\section{Sertão do Gentio Kayapó x Sertão da Farinha Podre}

A resistência dos índios Kayapós no seu território culminou em vários ataques que dificultavam o funcionamento do Sertão da Farinha Podre no Sertão do Gentio Kayapó. O Sertão da Farinha Podre era passagem da Estrada do Anhaguera para as Minas dos Goiazes, acontece que o Sertão da Farinha Podre estava no Sertão do Gentio Kayapó, território dos índios Kayapós.

De acordo com os dados do levantamento feito por de Mori (2015, p. 46-56), as Incursões Guerreiras dos Índios Kayapós do Sul na área do Sertão do Gentio Kayapó onde estava o Sertão da Farinha Podre tem o primeiro registro em 1744.

Considerando a data do primeiro registro 1774, sabemos que as Incursões Guerreiras dos Índios Kayapós do Sul na Região de Araxá ou começaram em meio à Grande Guerra do Campo Grande (1741-1760) ou começaram a ser registradas em meio à Grande Guerra do Campo Grande.

De qualquer forma, a partir do registro, sabemos que se tornaram oficiais para a Coroa.

Neste contexto, a condição do Sertão da Farinha Podre é de espaço de circulação, sem dinamismo próprio, é um espaço intermediário, constituído "em função das necessidades de intercâmbio das minas com o litoral”. (BESSA 2013)

A função do Sertão da Farinha Podre na engrenagem colonial tinha que ser preservada. Na configuração administrativa da colônia o Sertão da Farinha Podre pertencia à Capitania de São Paulo. Coube ao Governador da Capitania buscar uma solução para garantir os interesses da Coroa na região. 
CARTOGRAFIA DA FORMACÃO TERRITORIAL DE ARAXÁ - MINAS GERAIS - DO SERTÃO KAYAPÓ AO TRIÂNGULO MINEIRO E ALTO PARANAÍBA - HERANÇAS HISTORIOGRÁFICAS E BASES DA GÊNESE NO TERRITÓRIO DE CONFLITO.

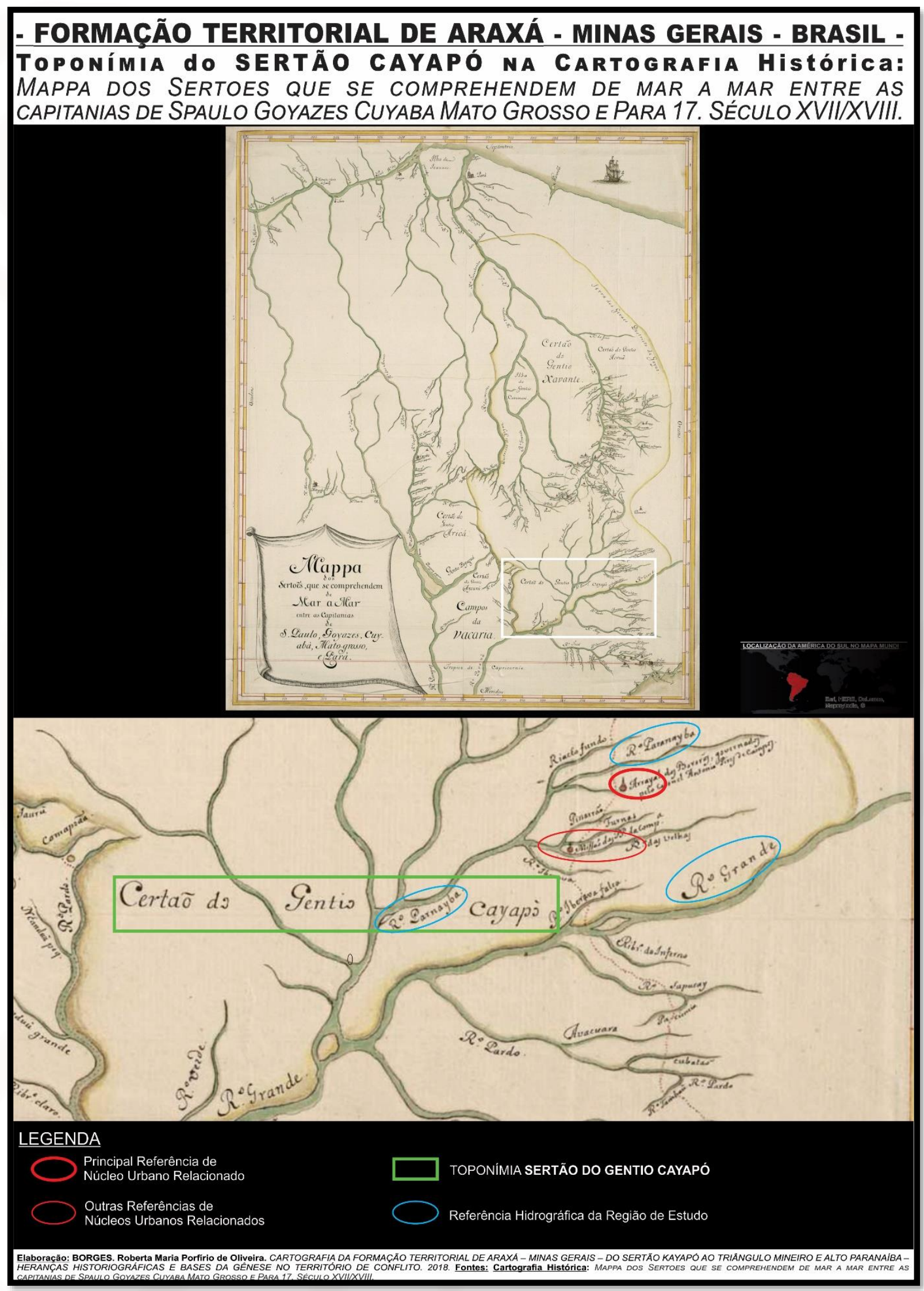

Figura 40 - Análise da Cartografia Histórica - Sertão Cayapó I - Século XVII-XVIII. 
CARTOGRAFIA DA FORMACÃO TERRITORIAL DE ARAXÁ - MINAS GERAIS - DO SERTÃO KAYAPÓ AO TRIÂNGULO MINEIRO E ALTO PARANAÍBA - HERANÇAS HISTORIOGRÁFICAS E BASES DA GÊNESE NO TERRITÓRIO DE CONFLITO.

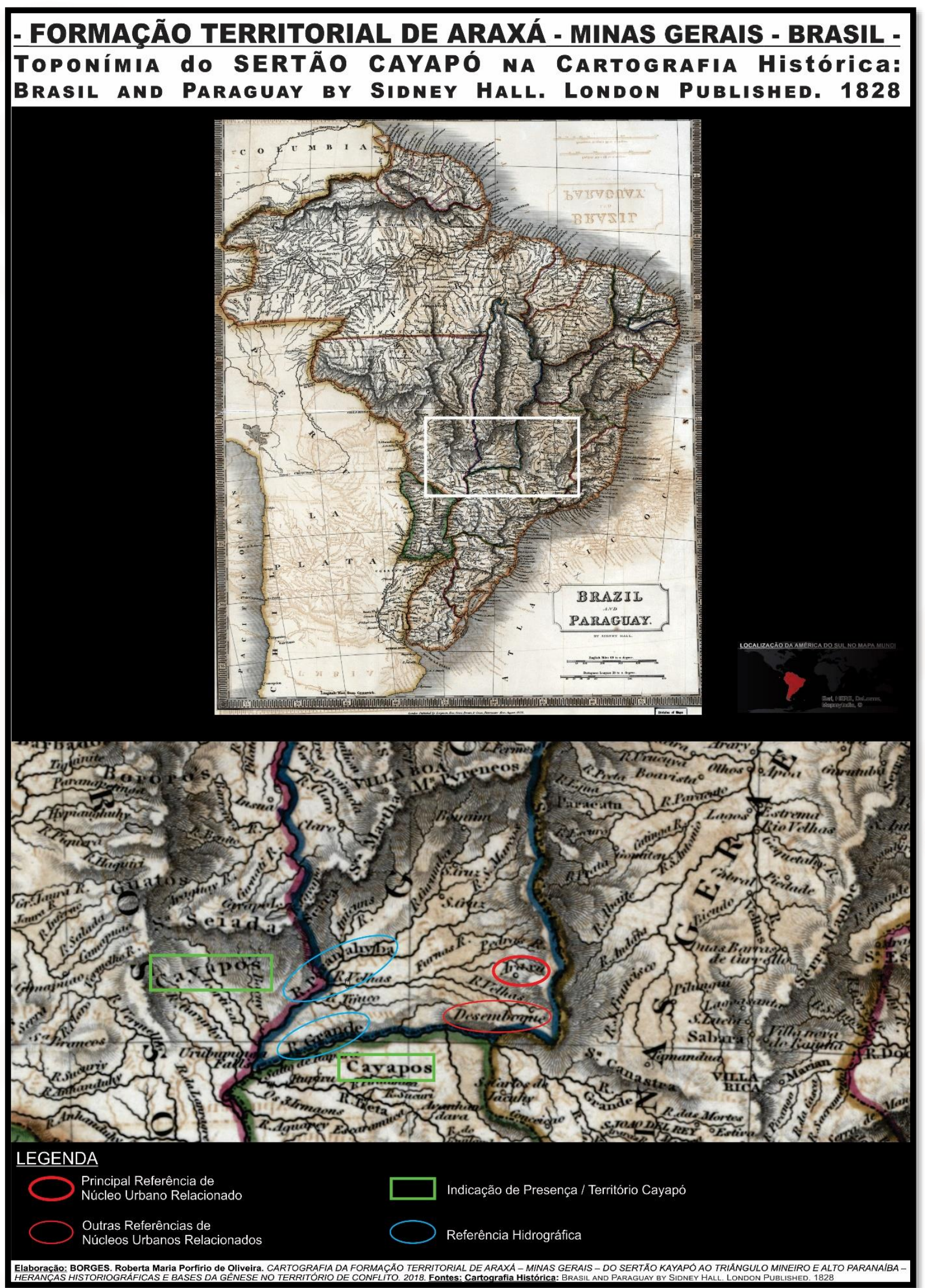

Figura 41 - Análise da Cartografia Histórica - Sertão Cayapó - 1828.

BORGES, Roberta Maria Porfírio de Oliveira. 2018. 


\section{Aldeamentos}

São diferentes dos Núcleos de Matriz Indígena, popularmente conhecidos como Aldeias, que são núcleos de formação própria e espontânea das Comunidades de Matriz Indígena que praticam livremente suas crenças e sua cultura.

Os Aldeamentos Indígenas consistem em núcleos, criados e governados por Bandeirantes atendendo aos interesses colonizadores, para abrigarem Comunidades de Matriz Indígena que atuariam a serviço da colonização.

"O governador e capitão general de São Paulo, Dom Luís de Mascarenhas, após autorização do monarca português, assinou um "ajuste" (contrato), em 1748, com o experimentado sertanista Antônio Pires de Campos, que comandava um exército de índios Bororó e Paresí, cujas aldeias foram subjugadas nos arredores de Cuiabá". (MORI 2017)

"No mesmo ano da assinatura do ajuste, 1748, Pires de Campos, com seu exército de índios, negros e mestiços, construiu um aldeamento denominado Rio das Pedras". (MORI 2015 apud MORI 2017)

Os Aldeamentos da Região do Antigo Araxá foram criados e dispostos com a intenção de promover segurança ao longo da Estrada do Anhanguera, que ligava São Paulo às Minas dos Goyazes. No Aldeamento de Rio das Pedras, governada pelo Coronel Antonio Pires de Campos, habitava população Indígena de Bororós, trazida do Mato Grosso, esta tinha função de Guerrear e Combater os Kayapós do Sul, ou seja, Povos de Matriz Indígena utilizados para combater uns aos outros.

"Os índios aldeados eram empregados no trabalho de manter o Caminho dos Goiases livre dos Kayapó do sul ou no revide dos ataques ocorridos em arraiais - conforme a categoria de guerra justa defensiva autorizada pelo monarca português". (MORI 2015 apud MORI 2017) 


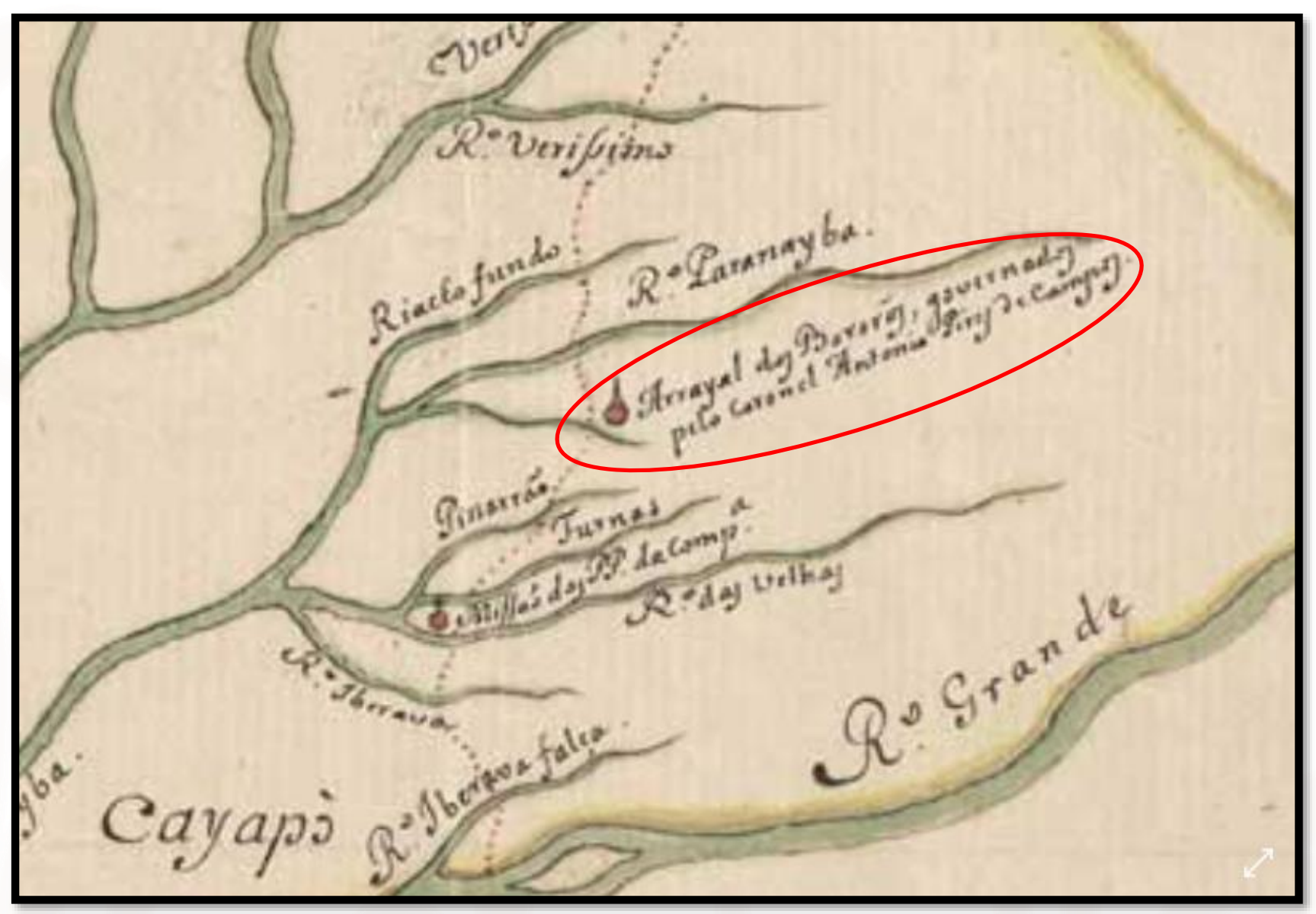

Figura 42 - Detalhe do Arraial dos Bororós na Cartografia Histórica.

Arraial do Bororós Governados pelo Coronel Antonio Pires de Campos - Detalhe, corroborador da natureza dos Aldeamentos na Região de Araxá, da Cartografia Histórica do Século XVIII: Mappa dos Sertoes que se comprehendem de mar a mar entre as capitanias de SPaulo Goyazes Cuyaba Mato Grosso e Para 17.

Logo após o Rio das Pedras, foi criado o aldeamento de Sant'Anna do Rio das Velhas, este, segundo Mori (2017), já a mando do Governo da nova Capitania de Goyaz (criada em 1749), para o aldeamento dos Índios Araxás que habitavam a região.

"Entretanto, após um severo ataque dos Kayapó do sul contra os Araxá que resultou no desbaratamento deste último grupo indígena, o governo de Goiás decidiu deslocar para Santa Ana do Rio das Velhas parte do contingente de índios aldeados em Rio das Pedras". (MORI 2017) 
Rio das Pedras e Sant'Anna do Rio das Velhas foram os principais núcleos de dispersão de núcleos indígenas ao longo do Caminhos dos Goiases. (MORI 2015, p. 174)

Considerando Aldeamentos (oficiais) os núcleos indígenas com Capelas, Lanhoso, São Domingos Estiva e Piçarrão também são Aldeamentos, no entanto, estes foram originados a partir de deslocamento de grupos de índios aldeados no Sertão da Farinha Podre. (MORI 2015, p. 174)

Sem capela, Boa Vista, Rocinha, Uberaba Falso e Baixa são Sítios Indígenas, que consistem em "pequenos núcleos resultados da dispersão espontânea da população [aldeada], ao longo da faixa de terras aldeanas, a partir dos aldeamentos verdadeiros". (LOURENÇO 2005, p. 87-88 apud MORI 2015, p. 173-174)

A dinâmica dos Aldeamentos do Sertão da Farinha Podre é caracterizada por "constantes deslocamentos de grupos indígenas culturalmente distintos e forçados a conviverem em um território delimitado", causando situações de conflito e cisões entre os índios aldeados. (MORI 2015, p. 174) 


\section{O último período da Grande Guerra do Campo Grande}

Até a metade do Século XVIII, além do ouro, os tratados internacionais, Tratado de Madri e Tratado de Santo Idelfonso, legitimaram e definiram grande parte das fronteiras brasileiras. A partir de 1750 acontece o período de apogeu e crise do antigo sistema colonial. (MORAES 2001, p.112)

Há ainda o início da era do Marquês de Pombal, entre suas ações, como a expulsão dos Jesuítas, uma de grande expressão é a finalização do Sistema Tributário de Capitação.

"Após aquele desastre, os novos representantes de Vila Rica192, apesar de sugerirem o aumento de todos os outros impostos para compensar a extinção da capitação, não eram contra as casas de fundição. Eram, isto sim, contra a derrama, isto, por saberem que 'Manda Vossa Majestade (...) que a derrama se faça à proporção dos bens', ou seja, '(...) pagando cada um à proporção do que tiver (...)', pois, como ricos que eram, achavam 'que a derrama há de causar maior estrago que a própria capitação, por ser raio que com maior violência cai sobre os homens ricos, e onde não há estes não podem viver os pobres'”. (MARTINS 2008, p. 72)

Mesmo com o fim da Capitação, seus efeitos se propagam, e suas marcas podem ser vistas no território. Ainda estava em curso a Grande Guerra do Quilombo do Campo grande.

"A Guerra do Campo Grande foi tão importante que o último ataque demorou três anos para ser preparado e motivou a transferência do governador para São João Del Rei (de onde comandou as operações)". (MATINS 2008, p. 97) 


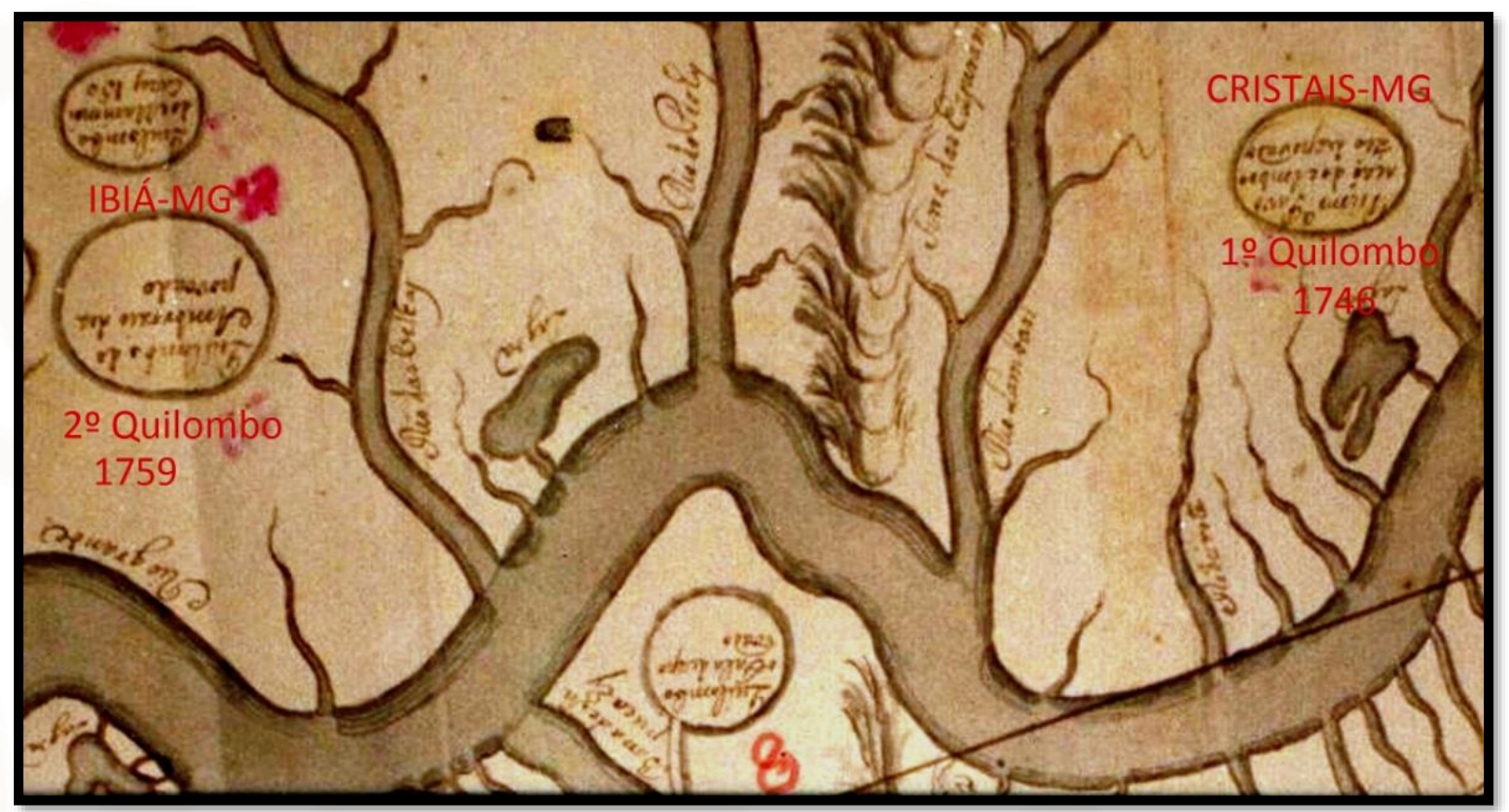

Figura 43 - Ambrósio II no mapa do Capitão Antônio Francisco França com os destaques feitos por MARTINS (2018). Detalhe da Cartografia Histórica: Mapa de Todo o Campo Grande 1760.

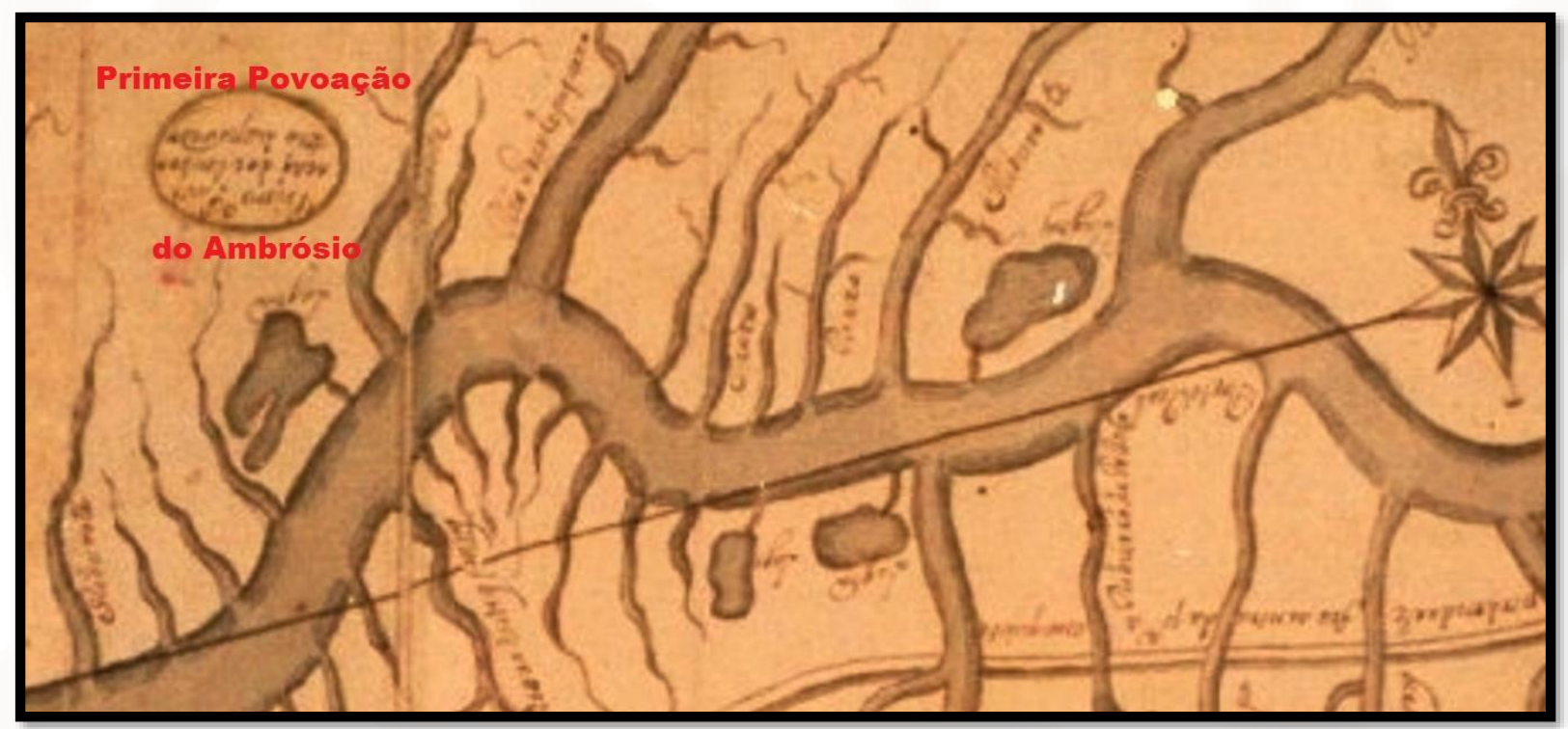

Figura 44 - Identificação da Primeira Povoação do Ambrósio feita por MARTINS (2018). Detalhe da Cartografia Histórica: Mapa de Todo o Campo Grande 1760. 
CARTOGRAFIA DA FORMAC̄̃O TERRITORIAL DE ARAXÁ - MINAS GERAIS - DO SERTÃO KAYAPÓ AO TRIÂNGULO MINEIRO E ALTO PARANAIIBA - HERANÇAS HISTORIOGRÁFICAS E BASES DA GÊNESE NO TERRITÓRIO DE CONFLITO.

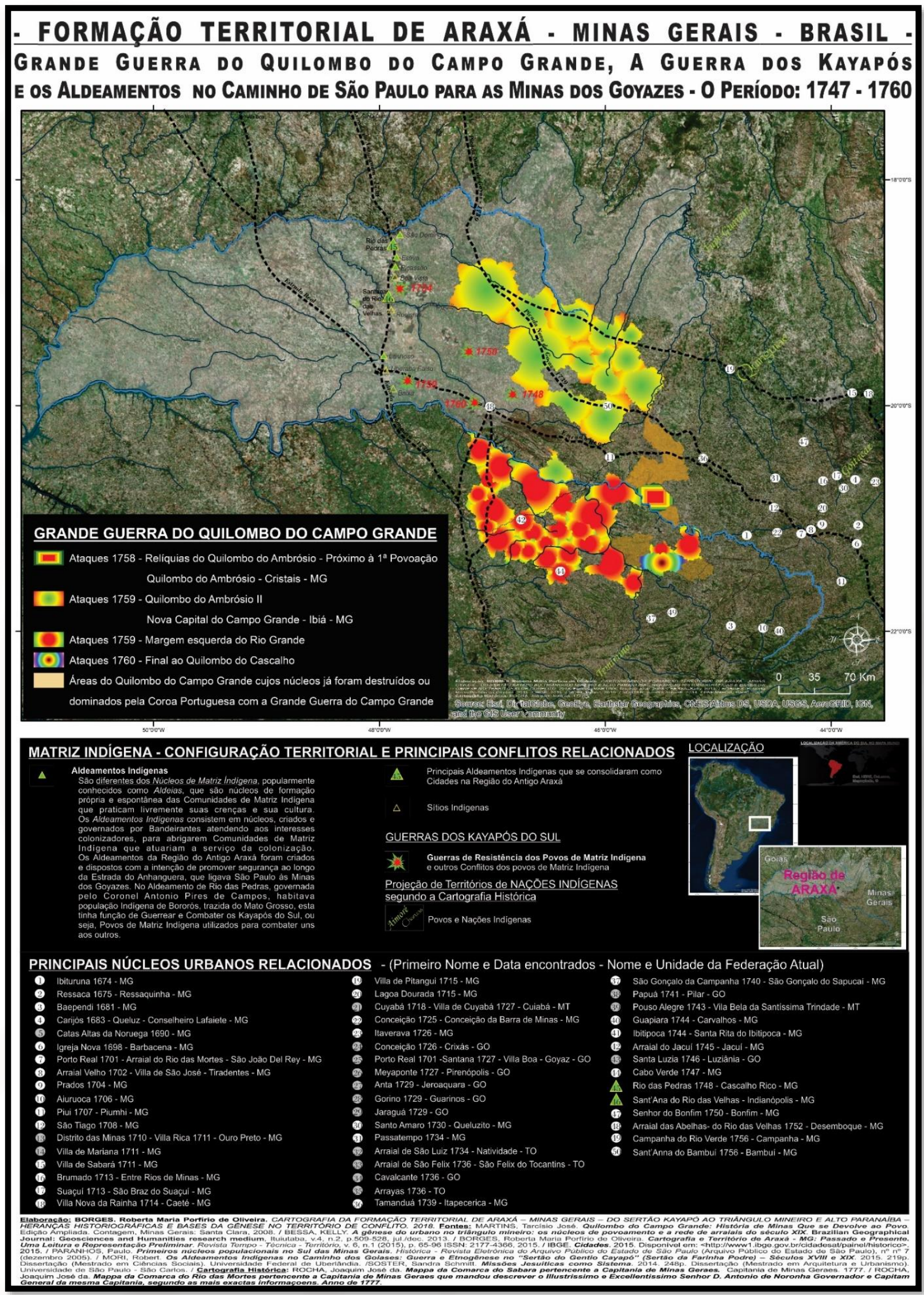

Figura 45 - Grande Guerra do Campo Grande e Guerra do Gentio Kayapó. 
Em um balanço da Grande Guerra do Campo Grande, Martins (2008, p. 792) opta pela pelo dado mais modesto do número de habitantes da Confederação Quilombola do Campo Grande entre os anos 1758-1760 em 9.942 pessoas, sem deixar de ressaltar que há dados e documentos que apontam para 15.552 e 20.000 habitantes na mesma Confederação Quilombola. Martins, sempre embasado em fontes documentais primárias, aponta que 93,34\% da população foi morta.

\section{GRANDE GUERRA DO QUILOMBO DO CAMPO GRANDE}

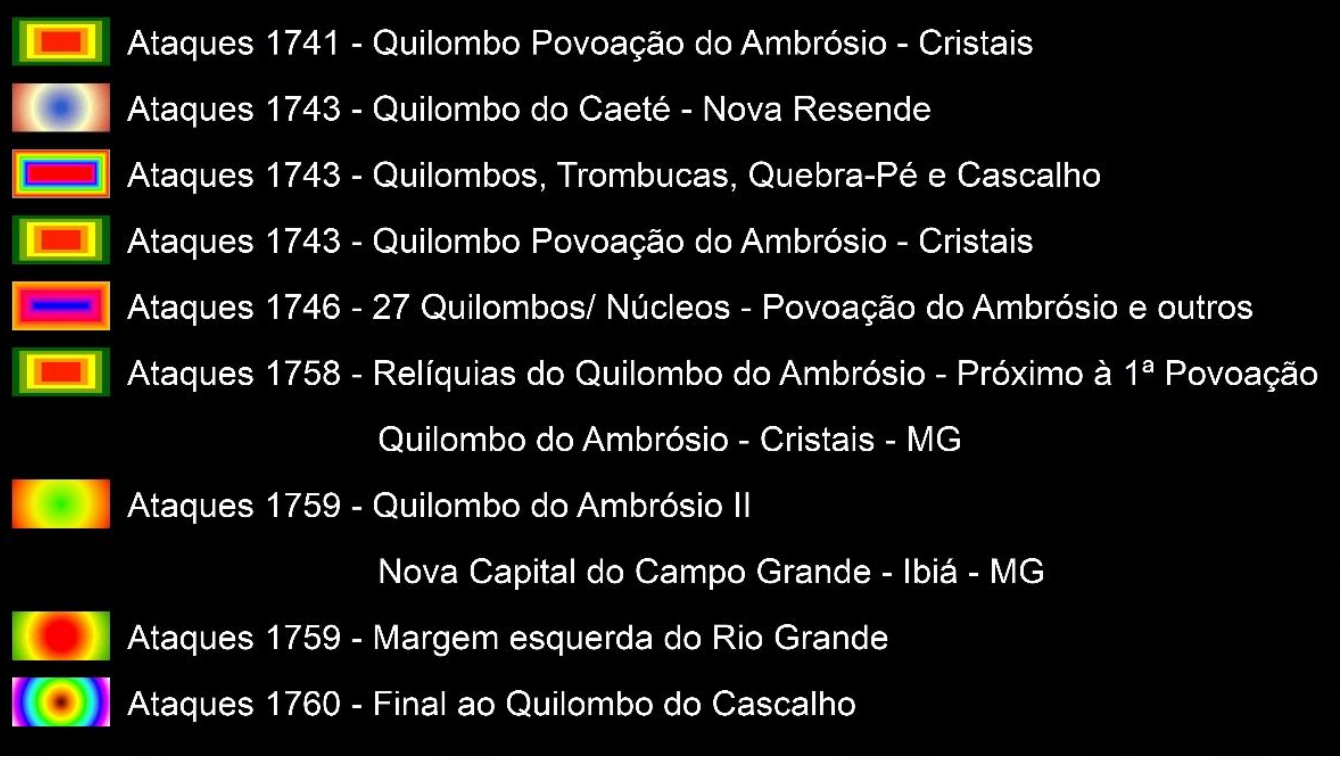

Figura 46 - Ataques ao Quilombo do Campo Grande.

A política de extermínio de Quilombos continua declaradamente, atravessando os governos, até 1768. (MARTINS 2008)

\section{A Gênese no Território de Conflito}

A Capitania do Rio das Mortes representa o contato da Região de Araxá com a Capitania de Minas Gerais, tanto por questão de fronteira com esta comarca da referida capitania, quanto pela importância dos processos que se desenvolveram na Comarca do Rio das Mortes para a Formação Territorial de Araxá.

A referência à Capitania de Minas Gerais, para a Formação Territorial de Araxá tem mais da Comarca do Rio das Mortes do que da Capitania como um todo. 
CARTOGRAFIA DA FORMAC̄̃̃ TERRITORIAL DE ARAXÁ - MINAS GERAIS - DO SERTÃO KAYAPÓ AO TRIÂNGULO MINEIRO E ALTO PARANAÍBA - HERANÇAS HISTORIOGRÁFICAS E BASES DA GÊNESE NO TERRITÓRIO DE CONFLITO.

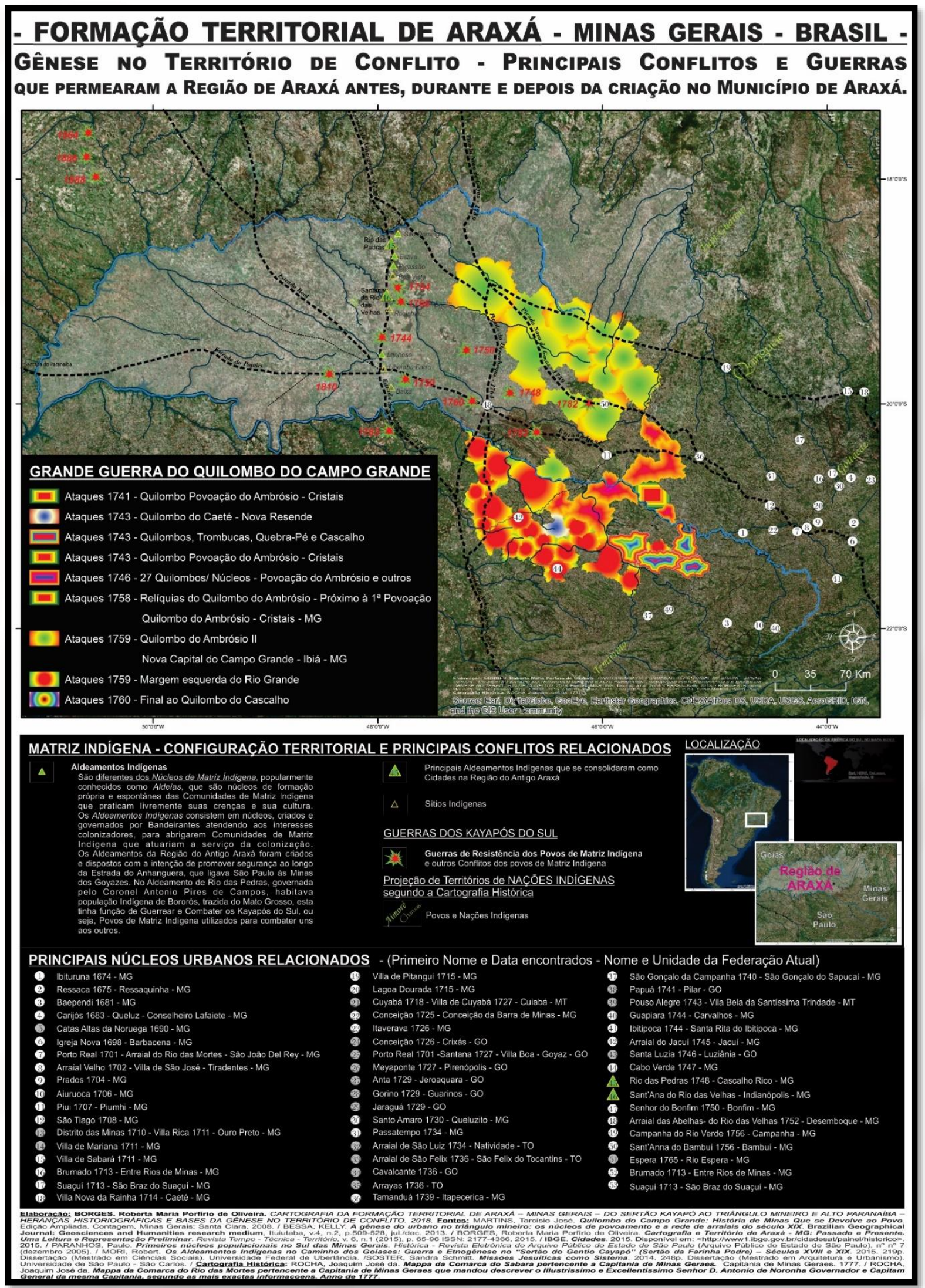

Figura 47 - Gênese no Território de Conflito. 
A Comarca do Rio das Mortes corresponde ao território que de fato ligava os centros administrativos "pós-governo geral", diacronicamente Rio de Janeiro, São Paulo e Vila Rica, à região que viria a ser o Território de Araxá.

A dinâmica territorial e as transformações do espaço da Comarca do Rio das Mortes têm considerável importância na Formação Territorial de Araxá. Esta importância é bem representada pela Grande Guerra do Campo Grande, que em grande parte acontecida também no território da Comarca do Rio das Mortes, e que precedeu a efetiva colonização da Região de Araxá. O Pós-Guerra do Campo Grande acontece na Comarca do Rio das Mortes e na Região do Antigo Araxá, onde, neste momento funciona o Sertão da Farinha Podre.

Araxá tem sua gênese neste Sertão da Farinha Podre que funciona em território do Sertão do Gentio Kayapó, e que também é lugar do Quilombo do Ambrósio, envolvido na Grande Guerra do Quilombo do Campo Grande. Estas são as linhas gerais da gênese no território de conflito.

O declínio do ciclo de mineração que se intensificou em época sincrônica ao início do núcleo urbano de Araxá pode ter aproximado mais os processos dos territórios do Pós-Guerra do Campo Grande, deixando suas marcas nas características desenvolvidas na Formação Territorial de Araxá.

"A comarca, que nunca dependera demasiadamente da mineração, supera com certa galhardia a crise econômica que se abateu sobre a Capitania, principalmente depois de 1780". A Comarca fornecia aos mercados toucinhos, queijos, algodão em rama, tecidos, chapéus de feltro, bois, bestas, galinhas, barras de ouro, acúcar, couros e fumo. (CARRATO 1968, p. 263, grifo nosso)

Esta característica da Comarca do Rio das Mortes, ressaltada por Carrato (1968) se assemelha à característica do Núcleo Urbano de Araxá.

"À medida que se agravavam os sintomas da crise do ouro, foram-se igualmente intensificando as atividades rurais para exportação, especialmente nas vertentes do Rio Grande, ou seja, 
banda são-joanense da Comarca do Rio das Mortes. A banda de Tiradentes, as vertentes do Rio São Francisco, voltava-se mais para o abastecimento da própria Capitania”. (MOURA, 2016.)

Guarda, portanto, a Comarca do Rio das Mortes semelhanças com alguns processos da formação do Núcleo urbano de Araxá, podendo-se considerar alguns elementos como propagação das dinâmicas da Comarca do Rio das Mortes na Região de Araxá.

O Arraial do Rio das Velhas ou como é mais conhecido, o Arraial do Desemboque, localizado no então Sertão da Farinha Podre, desabrochou com a mineração em meio aos conflitos do Campo Grande.

Desde o início do povoado que originou o Arraial, o Desemboque sofreu diversos ataques em meio à Guerra dos Kayapós do Sul (MORI 2015).

O Arraial se desenvolveu e ganhou importância no Sertão da Farinha Podre, que tinha função de espaço de circulação, como ligação do litoral com as minas do Goyaz, em meio aos aldeamentos, sítios indígenas, Guerra dos Kayapós do Sul e Quilombos.

Como característico da ocupação mineradora, a colonização promovida pelo Arraial foi pontual.

O Arraial que tudo suportou a Guerra dos Kayapós do Sul, a Guerra do Campo Grande, teve Cadeia própria e Milícia, se fortaleceu tornando-se Vila e Cabeça de Julgado, depois de anos de existência pontual em um espaço de circulação, sucumbiu ao declínio da mineração.

A sucumbência do Desemboque foi acontecendo à medida que o núcleo urbano, surgido com a demarcação da sesmaria do Barreiro e derivado da pecuária foi se fortalecendo com o crescimento das atividades de criação na região, a Freguesia de São Domingos do Araxá, que surgiu no território do Desemboque se tornou cabeça do Julgado de Araxá, Vila e Cidade.

No Sertão da Farinha Podre foram surgindo Povoados próximos às picadas em função do processo de migração geralista "que introduziu a presença de criadores e 
de roceiros oriundos do centro-sul da província mineira", com a utilização das pastagens naturais e fontes de água salgada desenvolvendo a pecuária e a agricultura de subsistência. (BESSA 2013, p. 514)

Bessa (2013) atribui a efetiva ocupação do Triângulo Mineiro (Sertão da Farinha Podre) ao favorecimento causado pelo declínio da mineração tanto na região central de Minas Gerais como em Goiás e Mato Grosso no final do século XVIII. O desenvolvimento das atividades que visam a posse do território transformou a condição de simples passagem. (BESSA 2013, p. 515)

As atividades pastoris e de subsistência, estimuladas pela concessão de sesmarias, que gerou condições de fixação do homem no território, gerou uma estrutura fundiária marcada pelas grandes propriedades de criação extensiva de gado e agricultura de subsistência. Assim, respondendo às necessidades de ocupação do território, tem-se a geração de centros urbanos próprios desta realidade de grandes propriedades rurais. (BESSA 2013, p. 515)

Os povoados a Arraiais pela ereção de uma capela, segundo Lourenço (2002, p. 197), a fundação dos Arraiais do Triângulo Mineiro são resultado de iniciativas das oligarquias rurais para a formação de patrimônios religiosos.

O processo de Formação territorial de Araxá segue seu curso, em sincronia com os ciclos em andamento na Capitania, no contexto das Comarcas limítrofes, especialmente a Comarca do Rio das Mortes, e com os demais ciclos urbanizadores que se desenrolavam no território da colônia.

Segundo Moraes (2001), em 1822 No momento da independência, apenas 1/5 do território brasileiro estava ocupado pela economia colonial, o restante constituía grandes fundos territoriais, a manutenção da soberania sobre esses fundos territoriais, juntamente com a manutenção do escravismo, levou a independência de forma monárquica, relacionando a soberania territorial à legitimação dinástica, presente no antigo regime monárquico, no qual os territórios pertenciam às casas reinantes, assim, a manutenção do príncipe português no brasil tornou a autonomia brasileira e seus territórios, internacionalmente e diplomaticamente, uma questão de família. (MORAES 2001, p. 112-113) 
CARTOGRAFIA DA FORMAC̄̃O TERRITORIAL DE ARAXÁ - MINAS GERAIS - DO SERTÃO KAYAPÓ AO TRIÂNGULO MINEIRO E ALTO PARANAÍBA - HERANÇAS HISTORIOGRÁFICAS E BASES DA GÊNESE NO TERRITÓRIO DE CONFLITO.

\begin{tabular}{|c|c|c|c|c|c|c|}
\hline \multicolumn{7}{|c|}{$\begin{array}{l}\text { FORMAÇÃO TERRITORIAL DE ARAXÁ - MINAS GERAIS } \\
\text { - FORMAÇÃO DO TERRITÓRIO DO MUNICÍPIO DE ARAXÁ - } 1608 \text { A } 1835 \text { - } \\
\text { O TERRITÓRIO DAS UNIDADES TERRITORIAIS E MODIFICAÇõES AdMINISTRATIVAS } \\
\text { RELACIONADAS }\end{array}$} \\
\hline $\begin{array}{l}\text { TEMPO } \\
\text { HISTÓRICO }\end{array}$ & \multicolumn{4}{|c|}{ UNIDADES AUTÔNOMAS - CAPITANIAS } & \multicolumn{2}{|c|}{ TERRITÓRIO ENTRE O RIO GRANDE E O RIO PARANAÍBA ${ }^{1}$} \\
\hline ANO & $\begin{array}{l}\text { TERRITÓRIO DA } \\
\text { CAPITANIA DO } \\
\text { RIO DE JANEIRO, } \\
\text { SĀO PAULO E } \\
\text { MINAS }\end{array}$ & $\begin{array}{l}\text { TERRITÓRIO DA } \\
\text { CAPITANIA DE SĀO } \\
\text { PAULOE MINAS DO } \\
\text { OURO }\end{array}$ & $\begin{array}{l}\text { TERRITÓRIO DA } \\
\text { CAPITANIA DE } \\
\text { MINAS GERAIS }\end{array}$ & $\begin{array}{l}\text { TERRITÓRIO DA } \\
\text { CAPITANIA DE } \\
\text { GOIAS }\end{array}$ & $\begin{array}{l}\text { TERRITÓRIO DA MARGEM DIREITA DO } \\
\text { RIO DAS VELHAS }{ }^{2}\end{array}$ & $\begin{array}{l}\text { TERRITÓRIO DA MARGEM } \\
\text { ESQUERDA DO RIO DAS VELHAS }\end{array}$ \\
\hline 1608 & \multicolumn{4}{|c|}{ CAPITANIA do RIo de JaNeIRo, São Paulo e Minas } & & \\
\hline 1709 & $\begin{array}{l}\text { CAPITANIA DO } \\
\text { RIO DE JANEIRO }\end{array}$ & \multicolumn{3}{|c|}{ Capitania de São Paulo e Minas do Ouro } & & \\
\hline 1721 & & $\begin{array}{l}\text { CAPITANIA DE } \\
\text { SÃO PAULO }\end{array}$ & $\begin{array}{l}\text { CAPITANIA DE } \\
\text { MINAS GERAIS }\end{array}$ & & & \\
\hline \multirow[t]{2}{*}{1736} & & & \multicolumn{4}{|c|}{ A PICADA DE GOYAZ É OFICIALMENTE ABERTA NA REGIĀO. B } \\
\hline & & & & $\begin{array}{l}\text { MINAS DE } \\
\text { GOYAZ }^{A}\end{array}$ & & $\begin{array}{c}\text { Passagem do Rio Grande e das } \\
\text { Velhas }^{A}\end{array}$ \\
\hline 1748 & & $\begin{array}{l}\text { CAPITANIA DE SÃo } \\
\text { PAULO }\end{array}$ & & $\begin{array}{l}\text { CAPITANIA DE } \\
\text { GOYAZ }\end{array}$ & Sertão da Farin & ha Podre ${ }^{3}$ \\
\hline 1752 & & & & & & $\begin{array}{c}\text { Arraial do Rio das Velhas / Arraial } \\
\text { das Abelhas }{ }^{B}-\text { Mineraçãa }^{A} \text { - } \\
\text { Diamantes }\end{array}$ \\
\hline \multirow[t]{2}{*}{1766} & & & & & \multicolumn{2}{|c|}{$\begin{array}{c}\text { Julgado das Cabeceiras do Rio das Velhas }{ }^{4} \text { (instituído oficialmente em } 2 \\
\text { de março) abarca todo o Sertão da Farinha Podre. }\end{array}$} \\
\hline & & & & & $\begin{array}{l}\text { Governo de Goyaz ordena "a prisão } \\
\text { de todos aqueles que embaraçarem a } \\
\text { exploração do território (...) entre o } \\
\text { Rio Paranaiba e o Rio das Velhas" A }\end{array}$ & $\begin{array}{l}\text { Criada Milícia auxiliar de } \\
\text { Ordenanças no Arraial das } \\
\text { Abelhas (ou das Velhas) }\end{array}$ \\
\hline $\begin{array}{l}1770 \mathrm{a} \\
1779\end{array}$ & & & & & $\begin{array}{l}1770 \text { - Começam as primeiras } \\
\text { fazendas de pastoreio na região de } \\
\text { Araxá }\end{array}$ & $\begin{array}{l}\text { Arraial de Nossa Senhora do } \\
\text { Desterro das cabeceiras do Rio } \\
\text { das Velhas }{ }^{6 ; 7}\end{array}$ \\
\hline $\begin{array}{l}1780 / \\
1789\end{array}$ & & & & & $\begin{array}{l}1785 \text { - Demarcação da Sesmaria do } \\
\text { Barreiro } \\
\begin{array}{c}1788 \text { - Celebração da primeira missa } \\
\text { no território de Araxác }\end{array}\end{array}$ & $\begin{array}{c}\text { Julgado das Cabeceiras do Rio das } \\
\text { Velhas }\end{array}$ \\
\hline 1791 & & & & & $\begin{array}{l}1791 \text { - Criada a FREGUESIA de São } \\
\text { Domingos do ARAXÁ }\end{array}$ & $\begin{array}{l}\text { Julgado das Cabeceiras do Rio das } \\
\text { Velhas }\end{array}$ \\
\hline 1811 & & & & & $\begin{array}{l}1811 \text { - JULGADO do ARAXÁ } \\
\text { Araxá elevado a Julgado e } \\
\text { desmembrado do Julgado das } \\
\text { Cabeceiras do Rio das Velhas }\end{array}$ & $\begin{array}{c}\text { Julgado das Cabeceiras do Rio das } \\
\text { Velhas }\end{array}$ \\
\hline \multirow[t]{2}{*}{$\begin{array}{l}1815 / \\
1816\end{array}$} & & & $\begin{array}{l}\text { Criada a } \\
\text { Comarca de } \\
\text { Paracatu }^{8}\end{array}$ & & \multicolumn{2}{|c|}{$\begin{array}{c}1816 \text { - Julgados de Araxá e do Desemboque, com todo o seu território, } \\
\text { são integrados à Capitania de Minas Gerais, anexados a Comarca de } \\
\text { Paracatu }\end{array}$} \\
\hline & & & & & Julgado do Araxá & Julgado do Desemboque ${ }^{B}$ \\
\hline 1831 & & & & & $\begin{array}{l}1831 \text { - ARAXÁ elevado a VILA, sede do } \\
\text { MunicípIO de São Domingos do Araxá }\end{array}$ & \\
\hline 1835 & & & & & \multicolumn{2}{|c|}{1835 - O Município de Araxá abarca todo o Sertão da Farinha Podre ${ }^{D}$} \\
\hline 1865 & & & & & 1865 - ARAXÁ elevado a CIDADE & \\
\hline \multicolumn{7}{|c|}{ 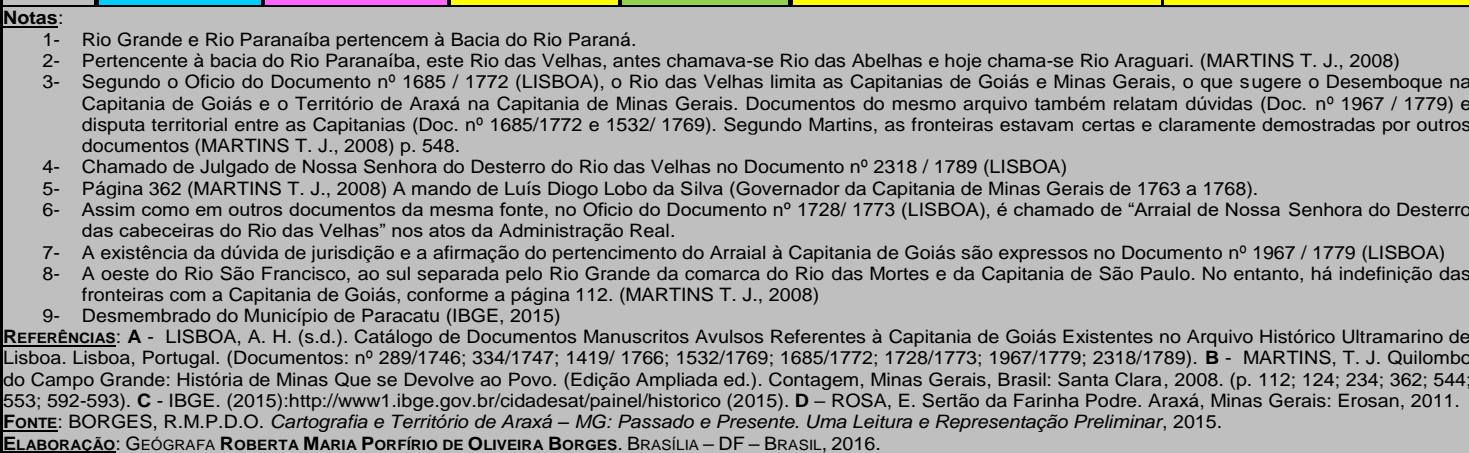 } \\
\hline
\end{tabular}

Quadro 2 - Formação do território do Município de Araxá. 


\section{Capítulo IV - O TeRRITÓRIO: DO ANTIGO}

MunicípIo de ARAXÁ AOS 76 MunicíPIOS do INÍCIO DO SÉCULO XXI

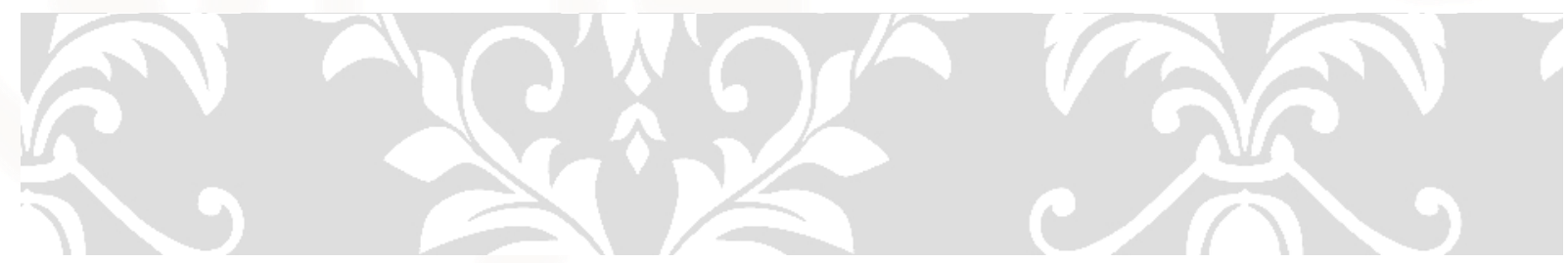




\section{Território de ARAXÁ}

Em Formação do Território do Município de Araxá - 1608 a 1835 (Quadro 2) toda a evolução administrativa da região de Araxá é demonstrada, especialmente a mudança de julgado para município em 1831, quando Araxá é elevado a Vila e tornase sede do Município de São Domingos do Araxá. Em Processo de desmembramento dos municípios oriundos do território do Município de Araxá - Minas Gerais - Brasil (Figura 47) é possível observar a configuração do Antigo Município de Araxá em 1836 e a partir desta unidade territorial, as transições administrativas do território do Antigo Município de Araxá ao longo de sua história. Em Área do Município de Araxá no decorrer do tempo histórico - Versão Preliminar (Gráfico 1), Processo de desmembramento dos municípios oriundos do território do Município de Araxá - Minas Gerais - Brasil - Linha do tempo da Área Aproximada dos municípios no respectivo ano de criação e área atual $\left(\mathrm{km}^{2}\right)$ (Figura 48) e Distribuição do Território do Antigo Município de Araxá ao longo do tempo histórico. (Figura 49) é demonstrada as mudanças de área do Município de Araxá, assim como dos municípios originários do Antigo Município de Araxá. O Antigo Município de Araxá definido em Cartografia e Território de Araxá. (BORGES 2015)

Área do Antigo Território de Araxá em relação à outras unidades territoriais nacionais e internacionais.

\begin{tabular}{|c|c|c|c|}
\hline \multicolumn{4}{|c|}{$\begin{array}{l}\text { ÁREA DO ANTIGO TERRITÓRIO DE ARAXÁ EM RELAÇÃO À OUTRAS } \\
\text { UNIDADES TERRITORIAIS NACIONAIS E INTERNACIONAIS }\end{array}$} \\
\hline \multicolumn{4}{|c|}{ CONTEXTO NACIONAL } \\
\hline Unidade Territorial & Tipo & Localização & Área $\left(\mathrm{km}^{2}\right)$ \\
\hline Antigo Município de Araxá & Município & Brasil & $105.307,010$ \\
\hline Santa Catarina & Estado & Brasil & $95.737,895$ \\
\hline Pernambuco & Estado & Brasil & $98.076,001$ \\
\hline Paraíba & Estado & Brasil & $56.468,427$ \\
\hline Rio Grande do Norte & Estado & Brasil & $52.811,110$ \\
\hline Espírito Santo & Estado & Brasil & $46.089,390$ \\
\hline Rio de Janeiro & Estado & Brasil & $43.781,566$ \\
\hline Alagoas & Estado & Brasil & $27.848,158$ \\
\hline Sergipe & Estado & Brasil & $21.918,454$ \\
\hline \multicolumn{4}{|c|}{ CONTEXTO INTERNACIONAL } \\
\hline
\end{tabular}

BORGES, Roberta Maria Porfírio de Oliveira. 2018. 


\begin{tabular}{|c|c|c|c|}
\hline Unidade Territorial & Tipo & Localização & Área $\left(\mathrm{km}^{2}\right)$ \\
\hline Antigo Município de Araxá & $\begin{array}{c}\text { Município } \\
\text { Minas Gerais } \\
\text { Brasil }\end{array}$ & América do Sul & 105.307 \\
\hline Islândia & País & Europa Insular & 103.000 \\
\hline Coréia do Sul & País & Ásia Oriental & 99.016 \\
\hline Hungria & País & Europa & 93.032 \\
\hline Portugal & País & Europa & 92.152 \\
\hline Guiana Francesa & $\begin{array}{l}\text { Departament } \\
\text { o Ultramarino } \\
\text { da França }\end{array}$ & América do Sul & 90.000 \\
\hline Jordânia & País & $\begin{array}{l}\text { Sudoeste } \\
\text { Asiático }\end{array}$ & 89.342 \\
\hline Áustria & País & Europa & 83.853 \\
\hline Emirados Árabes Unidos & País & $\begin{array}{l}\text { Sudoeste } \\
\text { Asiático }\end{array}$ & 83.600 \\
\hline \multicolumn{4}{|c|}{$\begin{array}{l}\text { FoNTES: IBGE, 2016. Área Territorial Brasileira: Consulta por Unidade da Federação: } \\
\text { http://www.ibge.gov.br/home/geociencias/areaterritorial/principal.shtm. Acesso em } \\
\text { 11/10/2016. / Internacional: Wikipedia.org. Acesso em 11/10/2016. } \\
\text { ELABORACÁO: GEÓGRAFA ROBERTA MARIA PORFíRIO DE OLIVEIRA BoRGES. BRASÍLIA - DF } \\
-2016\end{array}$} \\
\hline
\end{tabular}

\section{Quadro 3 - Área do Antigo Território de Araxá em relação à outras unidades territoriais nacionais e internacionais.}

\section{Processo de divisão dos municípios a partir do território do município de Araxá de 1835}

No ano de 1835 o município de Araxá abarcava todo o Sertão da Farinha Podre (Quadro 2), lugar no qual Araxá foi o primeiro núcleo urbano que vingou e permaneceu, tornando-se oficialmente uma cidade em 1865 (ROSA, 2011).

A partir de 1836, começou o processo de divisão do território do Município de Araxá, originando, até hoje, 76 municípios brasileiros, todos no estado de Minas Gerais (Quadro 6 e Figuras 47, 48 e 49). Em ampla pesquisa nos registros disponibilizados pelo IBGE (2015), foi feito o estudo da criação dos municípios, cujo resultado foi a constatação da abrangência do território do Município de Araxá em 1835 para além da Mesorregião do Triângulo Mineiro e Alto Paranaíba. Em 1835 o território do Município de Araxá correspondia aos territórios de 76 municípios do Estado de Minas Gerais, englobando todo o território da Mesorregião do Triângulo 
Mineiro e Alto Paranaíba (66 Municípios) além de partes das Mesorregiões do Noroeste de Minas (Presidente Olegário, São Gonçalo do Abaeté, Lagamar, Lagoa Grande e Varjão de Minas) e Central Mineira (Abaeté, Morada Nova de Minas, Biquinhas, Paineiras e Cedro do Abaeté) (Figura 47 - 1995-2015). A origem destes é demonstrada na pesquisa e representada na organização sistematizada (conforme Quadro 5) das informações oficiais encontradas sobre a criação de cada Município (Quadro 6).

Alguns territórios e frações de territórios pertenceram a diferentes municípios no decorrer das mudanças administrativas regionais, são meandros administrativos importantes, que demandam futura detalhada investigação. Visando facilitar a compreensão do processo aqui apresentado, consideramos a configuração administrativa local vigente no momento da criação de cada muncípio, de acordo com os dados fornecidos pelo IBGE (2015), de forma simplificada, assim, adotamos o último ou o mais expressivo pertencimento do território na época do desmembramento para classificar a origem imediata do municípios. Por questões metodológicas, a delimitação territorial é baseada na configuração atual dos municípios, também dada pelo IBGE (2015) que, com a soma dos territórios dos municípois desmembrados, fazemos uma projeção da área $\left(\mathrm{km}^{2}\right)$ (Figura 48 e Figura 49) e da delimitação do território dos municípios no tempo histórico (Figura 47), buscando representar sua configuração no passado (Figura 47 - 1835 a 1962).

\begin{tabular}{|c|c|c|c|c|c|c|c|c|}
\hline \multicolumn{9}{|c|}{ CÓDIGO DE ORIGEM TERRITORIAL DO MUNICÍPIO } \\
\hline \multicolumn{9}{|c|}{ CAMPOS DE CLASSIFICAÇÃO SEPARADOS POR PONTO (.) } \\
\hline $\begin{array}{l}\text { Origem } \\
\text { Territorial }\end{array}$ & \multicolumn{5}{|c|}{ Campos utilizados } & \multicolumn{3}{|c|}{ Campos possíveis } \\
\hline $\begin{array}{l}10 \\
\text { MUNICÍPIO } \\
\text { CRIADO }\end{array}$ & $\begin{array}{l}\text { 1a } \\
\text { GERAÇÃo }\end{array}$ & $\begin{array}{l}\mathbf{a} \\
\text { GERAÇÃO }\end{array}$ & $\begin{array}{l}\text { a } \\
\text { GERAÇÃO }\end{array}$ & $\begin{array}{l}4^{\mathrm{a}} \\
\text { GERAÇÃO }\end{array}$ & $\begin{array}{l}5 \mathrm{a} \\
\text { GERAÇÃO }\end{array}$ & $\begin{array}{l}\text { 6ạ } \\
\text { GERAÇÃO }\end{array}$ & $\begin{array}{l}7 \underline{7} \text { GERAÇÃO } \\
\text { Ger }\end{array}$ & ... \\
\hline \multicolumn{9}{|c|}{ REPRESENTADOS POR: } \\
\hline $\begin{array}{l}\text { Prefixo } \\
\text { (letras) }\end{array}$ & $\begin{array}{l}\text { Algarismo } \\
\text { Romano }\end{array}$ & $\begin{array}{l}\text { Letra } \\
\text { Maiúscula }\end{array}$ & $\begin{array}{l}\text { Algarismo } \\
\text { Arábico }\end{array}$ & $\begin{array}{l}\text { Letra } \\
\text { Minúscula }\end{array}$ & $\begin{array}{l}\text { Algarismo } \\
\text { Arábico }\end{array}$ & $\begin{array}{l}\text { Algarismo } \\
\text { Romano }\end{array}$ & $\begin{array}{l}\text { Letra } \\
\text { Maiúscula }\end{array}$ & $\ldots$ \\
\hline Arx. & I. (...) & A. (...) & 1. (...) & a. $(\ldots)$ & 1. $(\ldots)$ & I. $(\ldots)$ & A. $(. .)$. & $\ldots$ \\
\hline Arx. & I. & A. & 1. & a. & 1 & & & \\
\hline \multicolumn{9}{|c|}{ Arx.I.A.1.a.1 } \\
\hline \multicolumn{9}{|c|}{$\begin{array}{l}\text { OBSERVAČ̃̃O: APÓS O ÚLTIMO CAMPO DO CÓDIGO DE ORIGEM TERRITORIAL NÃO HÁ PONTO, EXCETO O CÓDIGO DO MUNICÍPIO } \\
\text { DE ARAXÁ (ArX.). }\end{array}$} \\
\hline \multicolumn{9}{|c|}{ 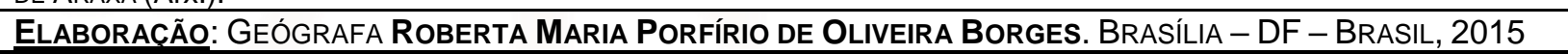 } \\
\hline
\end{tabular}

Quadro 4 - CÓDIGO DE ORIGEM TERRITORIAL DO MUNICÍPIO.

FONTE: BORGES, Roberta Maria Porfírio De Oliveira. Cartografia e Território de Araxá - MG: Passado e Presente. Uma Leitura e Representação Preliminar, 2015. 
A criação dos municípios foi dividida em gerações (Figura 47 e Quadro 6), considerando que o município de Araxá corresponde, em 1835, a totalidade da região (Figura 47 - 1835, Figura 48 e Figura 49), de forma similar a uma descendência familiar, os sete municípios criados pela divisão direta deste território correspondem à 1a geração: Uberaba (1836), Patrocínio (1840), Carmo do Paranaíba (1848), Sacramento (1870), Ibiá (1923), Perdizes (1938) e Santa Juliana (1938). A 2ª geração corresponde a desmembramentos ocorridos de municípios da $1^{\underline{a}}$ geração, a $3^{\underline{a}}$, de municípios da $2^{\underline{a}}$, a $4^{\underline{a}}$ de municípios da $3^{\underline{a}}$ e a $5^{\underline{a}}$ de municípios da $4^{a}$. Os municípios são classificados sequencialmente, de acordo com a data de criação de cada um, dentre os demais que foram desmembrados do mesmo município (Quadro 6). Ocorrendo, no futuro, novos desmembramentos, é possível acomodar os novos municípios na descendência seguindo a mesma lógica de classificação, de acordo com a ordem apropriada, inclusive, se necessário, em novas gerações.

Foi criado um código para cada município, denominado 'Código de Origem Territorial do Município', constituído, inicialmente, de seis campos separados por pontos (.), sendo o primeiro campo um prefixo $(A r x)$, referente à origem no primeiro município criado (Araxá) seguido dos demais campos, cada um referente ao município ascendente de cada geração de municípios (Quadro 5). Ao final do código não há ponto, indicando que o último campo corresponde ao próprio município, classificado em relação aos demais que possuem exatamente a mesma procedência. A exceção é o código do Município de Araxá, este composto unicamente pelo prefixo e finalizado com ponto (Arx.). 


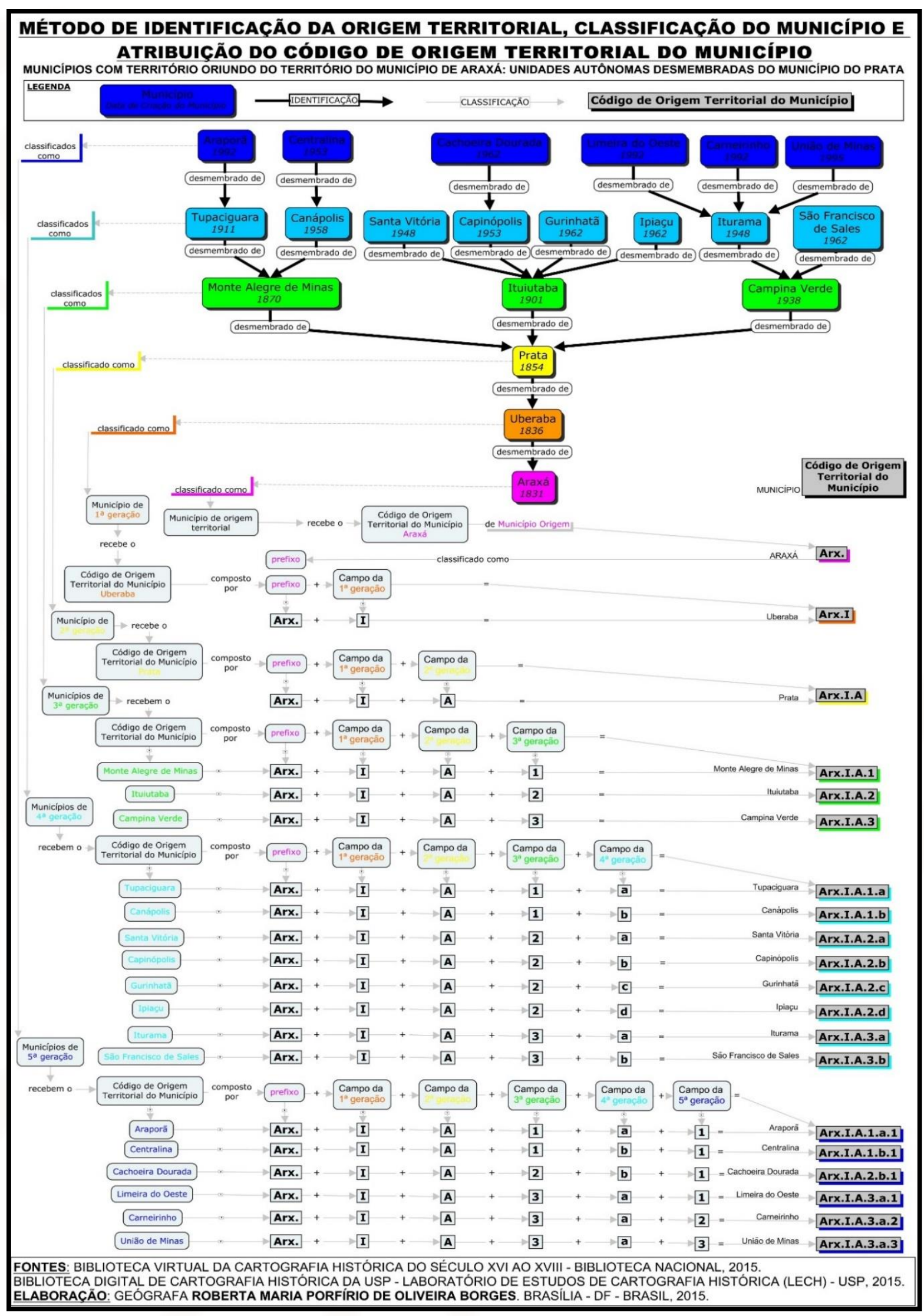

Quadro 5 - Método de Identificação da Origem Territorial, Classificação do Município e Atribuição do CÓDIGO DE ORIGEM TORRITORIAL DO MUNICíPIO. FONTE: BORGES, Roberta Maria Porfírio De Oliveira. Cartografia e Território de Araxá - MG: Passado e Presente. Uma Leitura e Representação Preliminar, 2015. 
CARTOGRAFIA DA FORMAC̄̃̃ TERRITORIAL DE ARAXÁ - MINAS GERAIS - DO SERTÃO KAYAPÓ AO TRIÂNGULO MINEIRO E ALTO PARANAÍBA - HERANÇAS HISTORIOGRÁFICAS E BASES DA GÊNESE NO TERRITÓRIO DE CONFLITO.

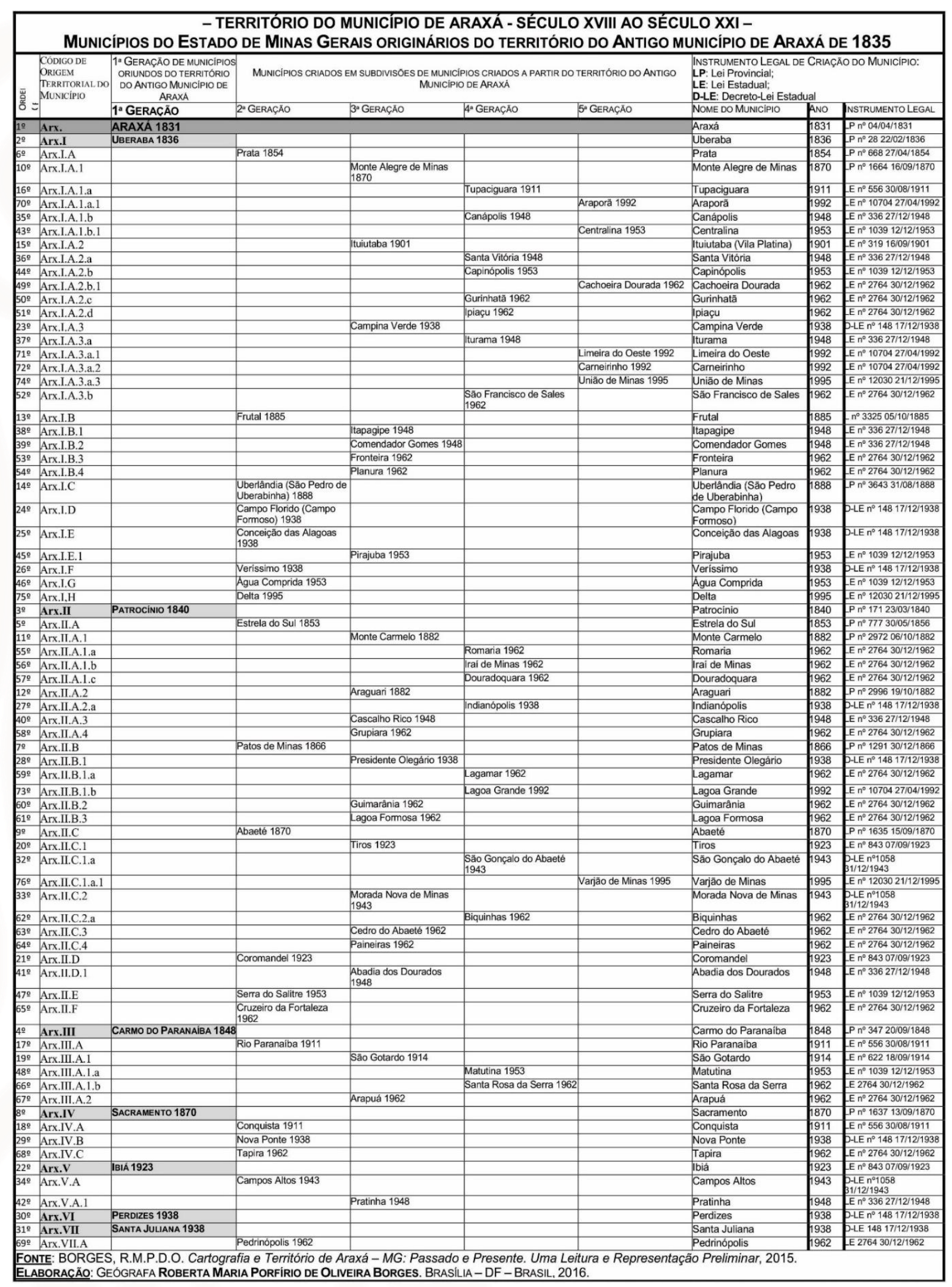

Quadro 6 - Território do Município de Araxá - Século XVIII ao Século XXI Municípios do Estado de Minas Gerais originários do território do município de Araxá de 1835.

FONTE: BORGES, Roberta Maria Porfírio De Oliveira. Cartografia e Território de Araxá - MG: Passado e Presente. Uma Leitura e Representação Preliminar, 2015. 


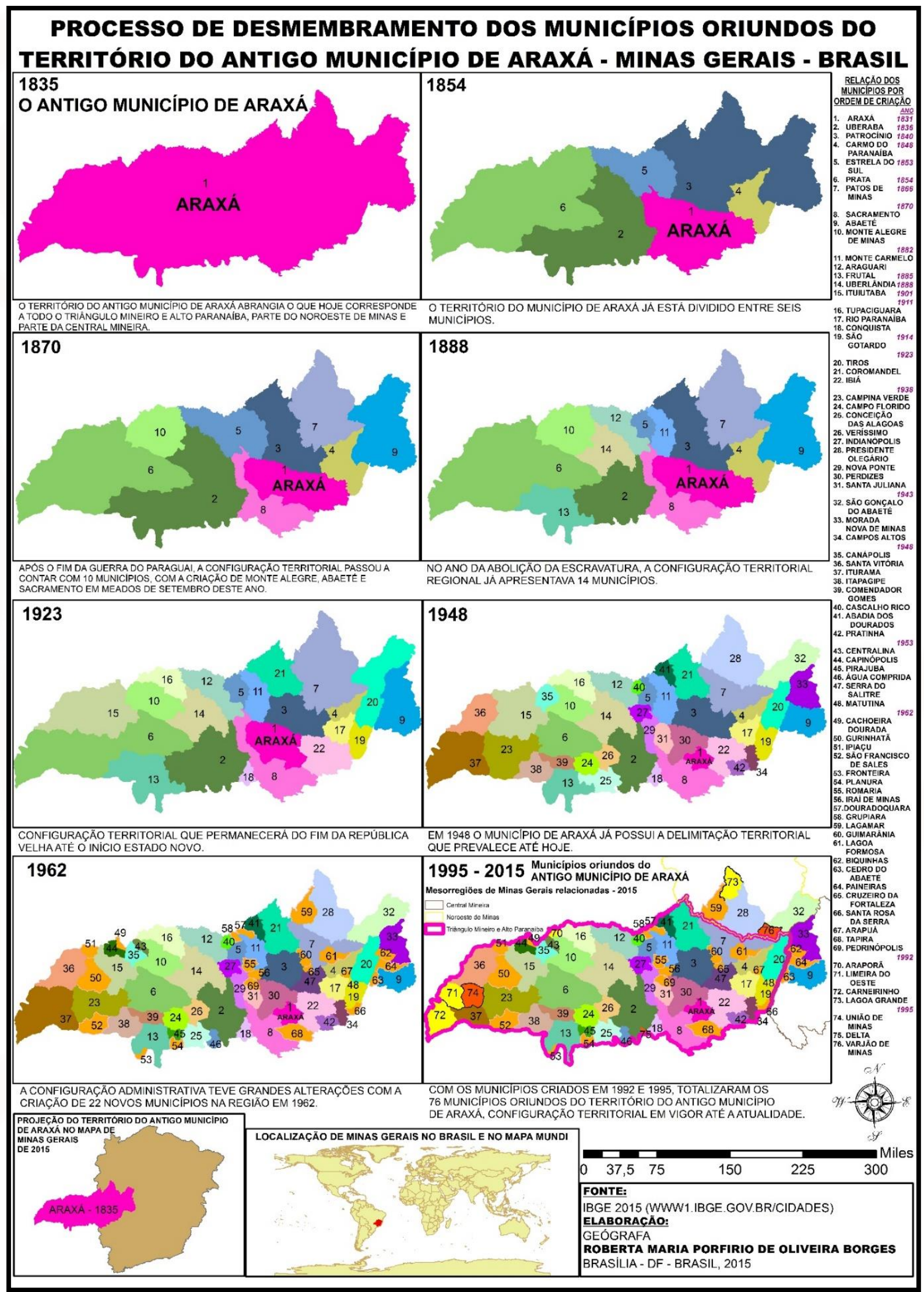

Figura 48 - Processo de desmembramento dos municípios oriundos do território do Município de Araxá - Minas Gerais - Brasil.

FONTE: BORGES, R.M.P.D.O. Cartografia e Território de Araxá - MG: Passado e Presente. Uma Leitura e Representação Preliminar, 2015. 
O processo de desmembramento dos 76 municípios oriundos do território do Antigo Município de Araxá implica na divisão deste território em territórios menores destinados aos novos municípios criados. Desta forma, o território do município de Araxá sofreu modificações desde o primeiro desmembramento, o Gráfico 1 demonstra as alterações da área do território do município de Araxá ao longo do tempo histórico conforme a criação de municípios de 1a geração (Quadro 4).

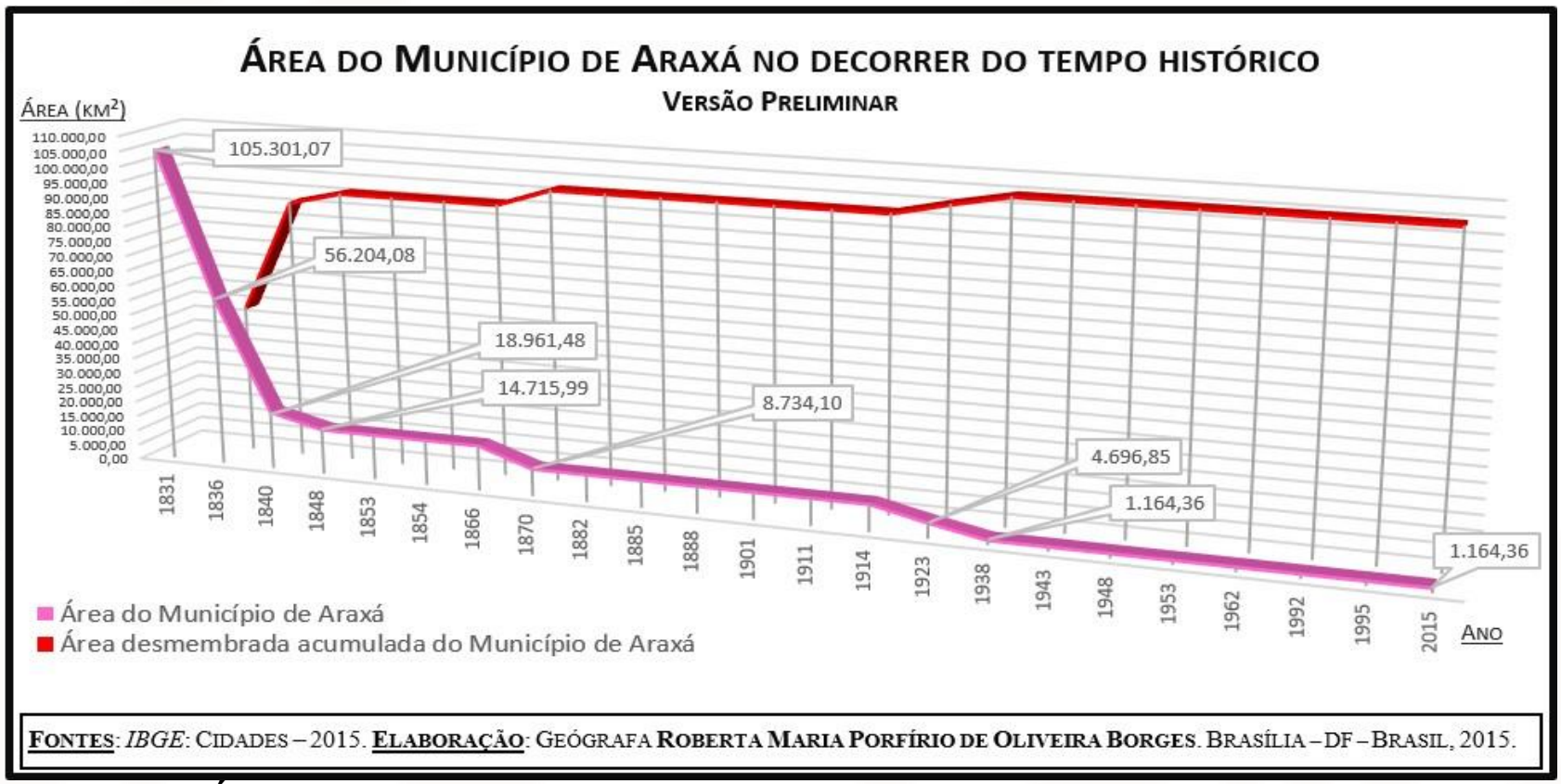

Gráfico 1 - Área do Município de Araxá no decorrer do Tempo Histórico. FONTE: BORGES, R.M.P.D.O. Cartografia e Território de Araxá - MG: Passado e Presente. Uma Leitura e Representação Preliminar, 2015.

Em Processo de desmembramento dos municípios oriundos do território do Município de Araxá - Minas Gerais - Brasil - Linha do tempo da Área Aproximada dos municípios no respectivo ano de criação e área atual $\left(\mathrm{km}^{2}\right)$ (Figura 48) são demonstradas as alterações das áreas dos territórios dos municípios ao longo do tempo histórico conforme a criação de municípios de $1^{\underline{a}}$ a 5 ${ }^{\mathfrak{a}}$ geração (Quadro 4).

A partir dos dados do IBGE (2015), as áreas atuais dos municípios foram somadas à área do respectivo município do qual procede o seu território, conforme a metodologia já usada para a identificação da origem e classificação dos municípios (Quadro 4), buscando obter de forma aproximada a área de cada município no momento de sua criação. Para retratar o processo de divisão do território em quilômetros quadrados $\left(\mathrm{km}^{2}\right)$ até a atualidade os municípios foram dispostos, com suas áreas no momento de sua criação, em uma linha do tempo que inicia em 1835 e se estende até o ano de 2015 (Figura 48). Os dados obtidos dispostos em um gráfico 
de barras (Figura 49) permitem a visualização da distribuição da área do território nos anos em que ocorreram alterações na configuração administrativa. Depois, foi calculada a fração do território, que corresponde a cada município na atualidade, em relação ao Antigo Município de Araxá (Figura 49 - Distribuição Territorial Atual). 
CARTOGRAFIA DA FORMAÇÃO TERRITORIAL DE ARAXÁ - MINAS GERAIS - DO SERTÃO KAYAPÓ AO TRIÂNGULO MINEIRO E ALTO PARANAIIBA - HERANÇAS HISTORIOGRÁFICAS E BASES DA GÊNESE NO TERRITÓRIO DE CONFLITO.

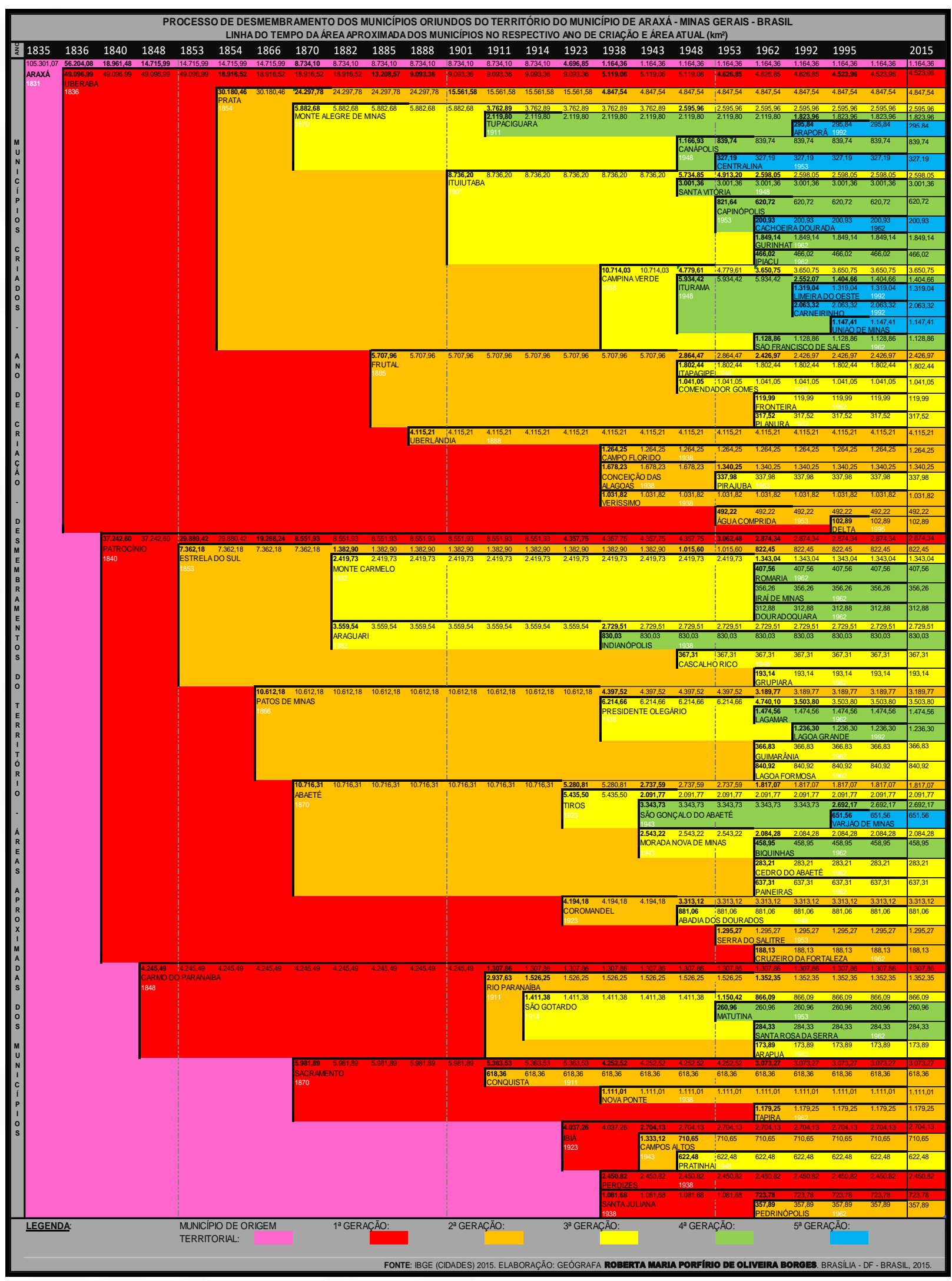

Figura 49 - Processo de desmembramento dos municípios oriundos do território do Município de Araxá - Minas Gerais - Brasil - Linha do tempo da Área Aproximada dos municípios no respectivo ano de criação e área atual $\left(\mathbf{k m}^{2}\right)$. FONTE: BORGES, Roberta Maria Porfírio De Oliveira. Cartografia e Território de Araxá - MG: Passado e Presente. Uma Leitura e Representação Preliminar, 2015. 


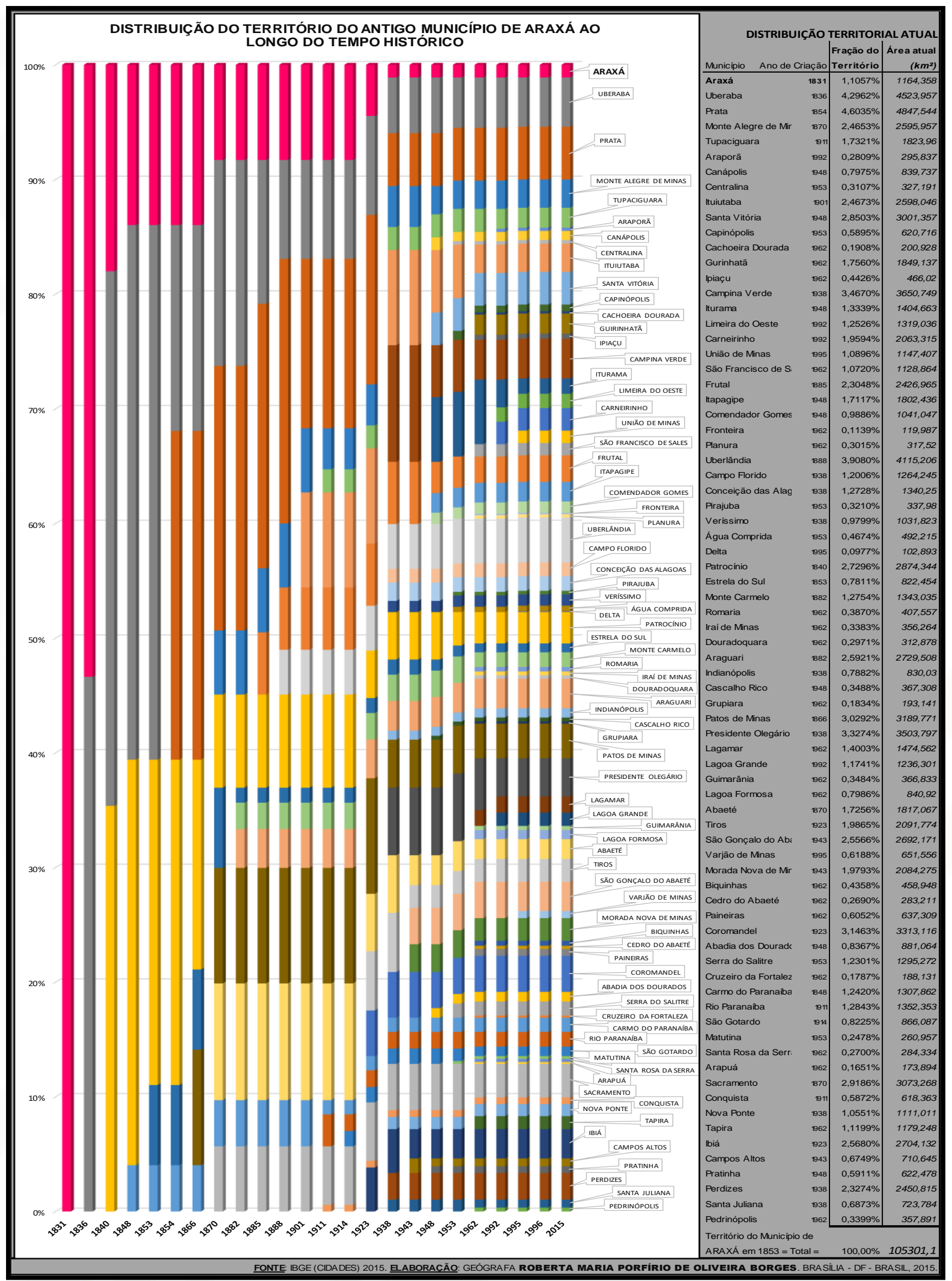

Figura 50 - Distribuição do Território do Antigo Município de Araxá ao longo do tempo histórico.

FONTE: BORGES, Roberta Maria Porfírio De Oliveira. Cartografia e Território de Araxá - MG: Passado e Presente. Uma Leitura e Representação Preliminar, 2015. 


\section{CONCLUSÕES E RECOMENDAÇÕES}

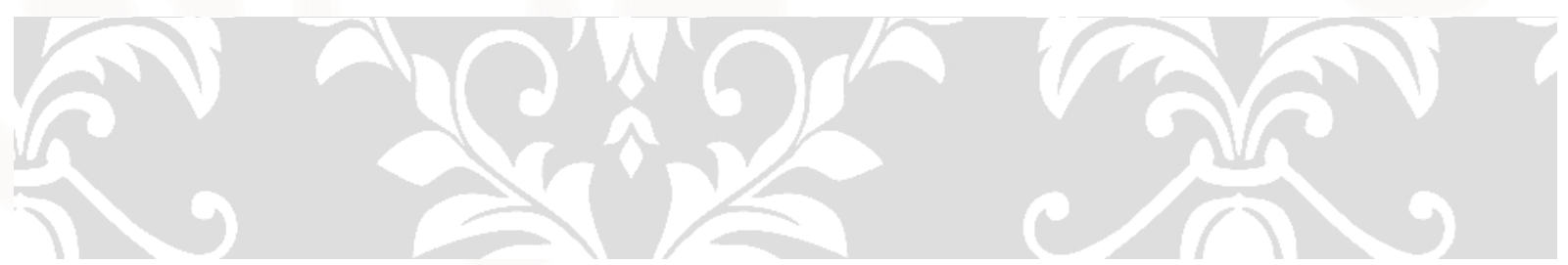


A Carta Magna (Constituição Federal/1988) confere aos municípios a atribuição de ordenar o seu território, de forma complementar aos demais entes. Assim, há ênfase no governo local, como ponto focal para promover um desenvolvimento espacial coerente, frente a dimensão dos desafios impostos por problemas territoriais complexos que não respeitam divisões administrativas e demandam, cada vez mais, a adoção de ações de governança integrada, para transcender as limitações das intervenções fragmentadas. Além de instrumentos de planejamento e gestão territorial, os municípios devem se respaldar de dados e conhecimentos que fundamentem a realização de diagnósticos, contemplando o olhar técnico e do agente social na prática de um planejamento compatível e integrado com todas as políticas e planos dos entes envolvidos.

Frente a dimensão dos desafios impostos por problemas territoriais complexos que não respeitam divisões administrativas e demandam, cada vez mais, a adoção de ações de governança integrada, para transcender as limitações de intervenções fragmentadas, além de instrumentos de planejamento e gestão territorial, os municípios devem se respaldar de dados e conhecimentos que fundamentem a realização de diagnósticos, contemplando o olhar técnico e do agente social na prática de um planejamento compatível e integrado com todas as políticas e planos dos entes envolvidos (Brasil, Ministério das Cidades, 2015).

A concepção, elaboração, implementação e avaliação de planejamentos estratégicos que permitam conciliar objetivos contrários e modelos de desenvolvimento conflituosos demanda o conhecimento da formação da configuração social e territorial regional para a compreensão do contexto histórico e das características sociais, políticas, econômicas e culturais da área de atuação (Brasil, Ministério das Cidades, 2015)

Neste contexto, assumem relevância os estudos que buscam desenvolver uma abordagem analítica da dinâmica territorial desenvolvida ao longo do tempo, orientados na perspectiva geográfica da contextualização e a espacialização das informações, contribuindo para a compreensão da dinâmica de desenvolvimento político-administrativo e explicação da territorialidade atual com seus conflitos e harmonias, o que proporciona embasamento para tomada de decisões coerentes com a história regional na gestão política do território. 
Assim sendo, no contexto local, o conhecimento da dinâmica de formação territorial e desenvolvimento do Município de Araxá ao longo do tempo é relevante para todos os municípios da região do Antigo Município de Araxá, permitindo, além do resgate histórico, a compreensão das características que permeiam os municípios da região.

Com a Cartografia da Formação Territorial de Araxá, a espacialização dos elementos deste processo confirmou a importância das transformações dos territórios que contextualizam a Região de Araxá e das dinâmicas territoriais de outras unidades como a Comarca do Rio das Mortes na Formação Territorial de Araxá.

A Cartografia da Formação Territorial de Araxá permitiu outras constatações por meio da análise dos documentos cartográficos produzidos:

A expansão da atividade mineradora para o Goyaz conferiu à Região de Araxá a função de espaço de circulação, ligando por meio da Estrada do Anhanguera o Litoral às minas do Goyaz, o que confirmou assim que este primeiro papel da Região de Araxá na engrenagem do sistema colonial não foi intrínseco à colonização do território, como em outros lugares onde a criação do caminho trazia a colonização.

Logo a Região de Araxá desempenhou outro papel no sistema colonial durante o ciclo do ouro: o de região de movimentos e ações de resistência. Na Cartografia da Formação Territorial de Araxá fica evidente a existência e persistência de dinâmicas dos movimentos de resistência de comunidades de matriz indígena - como os Kayapós do Sul - e de matriz africana - como os quilombos da Confederação Quilombola do Campo Grande.

A Cartografia da Territorialidade de Araxá também comprova que a gênese de Araxá foi em Território de Conflito ao tornar cartograficamente visível que o início do núcleo urbano se deu em região da Grande Guerra do Campo Grande e também da Guerra dos Kayapós do Sul.

Levando em Consideração o entendimento de Moraes (2001) de Território e de Formação Territorial, na Formação Territorial de Araxá as três dimensões são relacionadas especialmente à colonização do território, contemplando as três dimensões: Ideológica, Jurídica e Militar, correspondendo respectivamente à 
implementação da colonização, à criação das unidades administrativas coloniais e às guerras que devastaram os que combatiam a realização das duas primeiras dimensões.

A cartografia colonial e imperial analisada mostrou, em várias perspectivas, a representação da região delineada pelos Rios Grande e Paranaíba, naquele tempo era parte do Sertão do Gentio Kayapó, onde funcionou o colonial Sertão da Farinha Podre, até a época em que este território, dividido pelo Rio das Velhas, hoje denominado Rio Araguari, compreendeu à sua margem esquerda o Julgado do Desemboque e à margem direita o Julgado de Araxá.

O Desemboque desenvolveu-se com a mineração. Com o declínio da mineração, o Desemboque sofreu perdas determinantes, especialmente de habitantes, enquanto o aumento da criação de gado fortalecia o Araxá. Em 1831 é criado o Município de Araxá. Consolidado, em 1835, o Município de Araxá possuía um território de, aproximadamente, 105.307,01 km², o Antigo Município de Araxá, abrangendo toda a região entre os Rios Grande e Paranaíba em extensão superior à que hoje é chamada de Triângulo Mineiro. O desenvolvimento da região demandou de forma crescente a proximidade da administração dos núcleos urbanos que foram surgindo e se estabelecendo. Em 1836 começou o processo de divisão do Antigo Município de Araxá.

Desde 1831, há 184 anos, houve a criação de 76 municípios com o território do Antigo Município de Araxá, estas criações ocorreram em 22 momentos diferentes. Chamamos de momento o ano em que ocorreu criação de um ou mais municípios. Os quatro primeiros momentos ocorreram na $1^{\text {a }}$ metade do século $\mathrm{XIX}(1831,1836,1840$ e 1848), em cada um destes momentos apenas um município foi criado, assim ocorre também em cinco $\left(1853,1854,1866,1885\right.$ e 1888) dos sete momentos da $2^{a}$ metade do século XIX (1853, 1854, 1866, 1870, 1882, 1885 e 1888), sendo que em dois momentos deste período foram criados mais de um município (3 municípios em 1870 e 2 municípios em 1882).

Com a virada do século, na 1a metade do século XX há sete momentos (1901, 1911, 1914, 1923, 1938, 1943 e 1948) em apenas dois ocorre a criação de um município por vez (1 município em 1901 e 1 município em 1914), os demais momentos 
são de criação múltipla (3 em 1911, 3 em 1923, 9 em 1938, 3 em 1943 e 8 em 1948), adicionando 28 novos municípios a região.

A $2^{\text {a }}$ metade do século XX foi marcada por apenas 4 momentos, nos quais 34 municípios foram criados: 6 em 1953, 21 em 1962, 4 em 1992 e 3 em 1995. Destacase que 21 municípios foram criados em 1962, o que representa 27,63\% do total de municípios, é o ápice da concentração da criação de municípios na região. A modificação na configuração político-administrativa regional, em 1962, consiste em cerca de $11,03 \%\left(11.617,58 \mathrm{~km}^{2}\right)$ do território total (aproximadamente 105.301,07 $\mathrm{km}^{2}$ ), que passa a constituir os novos municípios.

Dos 22 momentos de criação, metade (11) ocorreram no século XIX e a outra metade no século XX, no entanto, no século XIX, 14 municípios foram criados, 18,42\% do total, enquanto 62 municípios foram criados no século $X X, 81,58 \%$ do total.

O território do Antigo Município de Araxá hoje corresponde aos territórios de 76 municípios do Estado de Minas Gerais, abrangendo todo o território da Mesorregião do Triângulo Mineiro e Alto Paranaíba (66 Municípios) além de partes das Mesorregiões do Noroeste de Minas (Presidente Olegário, São Gonçalo do Abaeté, Lagamar, Lagoa Grande e Varjão de Minas) e Central Mineira (Abaeté, Morada Nova de Minas, Biquinhas, Paineiras e Cedro do Abaeté) (Figura 11 - 1995-2015). Da configuração territorial do Estado brasileiro de Minas Gerais vigente no ano de 2015, que conta com 853 municípios, 76 são oriundos do território do Antigo Município de Araxá, o que corresponde a, aproximadamente, 8,9\% dos municípios do Estado e $1,3 \%$ dos 5.568 municípios do país.

A Cartografia da Formação Territorial de Araxá, possibilita a visualização, ao longo do tempo, da expressão territorial de fases, dinâmicas e processos da Formação Territorial de Araxá e de outras unidades territoriais envolvidas, como por exemplo, os 76 municípios oriundos do Território do Antigo Araxá ou ainda de núcleos urbanos de gênese colonial oriundos do território da Comarca do Rio das Mortes.

A Cartografia da Formação Territorial de Araxá fornece foi realizada em documentos articulados, mas independentes, sendo, portanto, cada um capaz de isoladamente prestar o entendimento as informações nele tratadas. Este formato de cartas independentes possibilita mais versatilidade para a utilização dos documentos 
cartográficos em diversos lugares e situações como escolas, escritórios e repartições públicas, para ensino, estratégias empresariais e decisões do poder público em que o histórico do município ou da região seja relevante.

O conhecimento da evolução administrativa regional contribui para a compreensão do contexto histórico e para a concepção, elaboração, implementação e avaliação de planejamentos estratégicos que permitam conciliar objetivos contrários e modelos de desenvolvimento conflituosos. Neste contexto, esta história dos mapas e espacialização das informações oficiais sobre a formação administrativa dos municípios, visam contribuir para a compreensão da dinâmica de desenvolvimento político-administrativo e explicação da territorialidade atual com seus conflitos e harmonias, proporcionando embasamento para tomada de decisões coerentes com a história regional na gestão política do território. 


\section{REFERÊNCIAS BIBLIOGRÁFICAS}

ANJOS, Rafael Sanzio Araújo dos. Territórios das Comunidades Remanescentes de Antigos Quilombos no Brasil - Primeira Configuração Espacial. 2ª . Brasília: Mapas Editora \& Consultoria, 2000.

ANJOS, Rafael Sanzio Araújo dos. Relatório de Campo no Quilombo do Campo Grande / Ambrósio MG. Tempo - Técnica - Território 1 (2010): 36.

BARBO, Lenora de Castro. Goiás nos Mapas: Representações do Territórios em Disputa. In: 3ํㅗㅇ Simpósio Brasileiro de Cartografia Histórica, 3, Belo Horizonte, 2016. Belo Horizonte-MG: CRCH/UFMG, 2016. p. 96-106.

BENTO, Cláudio Moreira, Cel et GIORGIS, Luiz Ernani Caminha, Cel. Brasil Lutas Internas 1500/1916. Resende/Barra Mansa: FAHIMTB/IHTRGS, 2016. ISBN: 978-8560811-26-7, 2016.

BESSA, KELLY. A gênese do urbano no triângulo mineiro: os núcleos de povoamento e a rede de arraiais do século XIX. Brazilian Geographical Journal: Geosciences and Humanities research medium, Ituiutaba, v.4, n.2, p.509-528, jul./dec. 2013.

BORGES, Roberta Maria Porfírio de Oliveira. Cartografia e Território de Araxá - MG: Passado e Presente. Uma Leitura e Representação Preliminar. Revista Tempo Técnica - Território, v. 6, n.1 (2015), 65:96 ISSN: 2177-4366, 2015.

BRASIL, Governo Federal do. Ministério das Cidades. Estatuto da Cidade - Lei no 10.257, de 10 de julho de 2001. 2001.

BRASIL, Biblioteca Nacional do. Biblioteca Virtual da Cartografia Histórica do Século XVI ao XVIII: http://consorcio.bn.br/cartografia/apresentacao.html. (20 de março de 2015).

BRASIL, República Federativa do. Constituição Federal. 1988.

BRASIL, Câmara dos Deputados. Arquivo Histórico. Disponível em: $<$ http://arquivohistorico.camara.leg.br>

CARRATO, José Ferreira. Igreja Iluminismo e escolas mineiras coloniais. Nacional. São Paulo, 1968

CARRATO, José Ferreira. Capitania de Minas Gerais nos fins da era colonial. Compilação: Acervo Cartografico do Arquivo Público Mineiro - APM. s.d.

CEZARIO, Leandro Fazollo. A estrutura jurídica no Brasil colonial. Criação, ordenação e implementação. Revista Âmbito Jurídico (Rio Grande) XIII (jan 2010).

CINTRA, Jorge Pimentel. Reconstruindo o Mapa das Capitanias Hereditárias. Anais do Museu Paulista. N. Sér. v. 21, n.2, p. 11- 45. Jul.-dez. 2013. 
CORDEIRO, Cecília Siqueira. Historiografia e História da Historiografia: alguns apontamentos. XXVIII Simpósio Nacional de História. Lugares dos Historiadores: Velhos e Novos desafios, 2015.

DIALÉTICO. Brasil Colônia: Estrutura Político-Administrativa. História Geral \& do Brasil. 2015. www.dialetico.com.br (acesso em 2015).

ELLIS, Myriam. As Bandeiras na Expansão Geográfica do Brasil. In: História Geral da Civilização Brasileira. Tomo I: A Época Colonial. V. 1. Do descobrimento à expansão territorial, por Sérgio Buarque de HOLANDA, 300-324. Rio de Janeiro: Bertrand Brasil, 2003.

FERREIRA, João Carlos Vicente. História de Vila Bela da Santíssima Trindade. Vila Bela da Santíssima Trindade. Portal Mato Grosso.Disponível em: <http://portalmatogrosso.com.br>, 2017.

FILHO, Ives Gandra da Silva Martins. Evolução histórica da estrutura judiciária brasileira. Revista Jurídica Virtual. Subchefia para Assuntos Jurídicos. Casa Civil. Presidência da República. vol.1, n. 5, setembro 1999.

FILHO, Ives Gandra da Silva Martins. O Ordenamento Jurídico Brasileiro. Revista Jurídica Virtual da Subchefia para Assuntos Jurídicos da Casa Civil da Presidência da República, v. 1, n. 3, julho 1999.

FURTADO, Celso. A Formação Econômica do Brasil. 27. São Paulo: Nacional, 1998.

HACK, Rafael Fernando. História e Historiografia. 2011. http://pedrodaveiga.blogspot.com.br/2011/03/historia-e-historiografia.html.

IBGE. Cidades. 2015: http://www1.ibge.gov.br/cidadesat/painel/historico. 2015.

ITAPECERICA, Prefeitura Municipal de. História de Itapecerica MG. Disponível em:<http://www.itapecerica.mg.gov.br/conteúdo/história>. Acesso em 02 de fevereiro de 2017.

LAEMMERT, Almanak. Annuario Administrativo, Agricola, Profissional, Mercantil e Industrial da República dos Estados Unidos do Brasil para 1917. Vol. 2. Rio de Janeiro: Officinas Typograficas do Almanak Laemmert, 1917.

MARTINS, A. de Assis, e J. Marques de OLIVEIRA, Almanak Administrativo, Civil e Industrial da Provincia de Minas Geraes para o anno de 1865. Ouro Preto, Minas Geraes: Typographia do Minas Geraes, 1864.

MARTINS, Antônio de Assis, ed. Almanak Administrativo, Civil e Industrial da Provincia de Minas-Geraes do anno de 1869 para servir no de 1870. Rio de Janeiro: Typographia do Diario do Rio de Janeiro, 1870.

MARTINS, Tarcísio José. Quilombo do Campo Grande: História de Minas Que se Devolve ao Povo. Edição Ampliada. Contagem, Minas Gerais: Santa Clara, 2008. 
MARTINS, Tarcísio José. O Ambrósio - 1759 do Capitão Antônio Francisco França - 1760 em MG Quilombo - O Quilombo Minas Gerais. Disponível em: http://novo.mgquilombo.com.br/imagens-quilombolas/o-ambrosio-1759-do-capitaoantonio-francisco-franca-1760/. Acesso em 24 de janeiro de 2018.

MATTOS, Odilon Nogueira de. A guerra dos Emboabas. In: História Geral da Civilização Brasileira. Tomo I: A Época Colonial. V. 1. Do descobrimento à expansão territorial, por Sérgio Buarque de HOLANDA, 300-324. Rio de Janeiro: Bertrand Brasil, 2003.

MATTOS, Raimundo José da Cunha. Carta Corográfica Plana da Província de Goyaz e dos Julgados de Araxá e Desemboque da Província de Minas Geraes. Goyaz, 1826/1836. 1836.

MORAES, Antônio Carlos Robert de. Bases da Formação Territorial do Brasil. GEOGRAFARES, nำ2, jun. 2001: 105-113.

MORI, Robert. Os Aldeamentos Indígenas no Caminho dos Goiases: Guerra e Etnogênese no "Sertão do Gentio Cayapó" (Sertão da Farinha Podre) - Séculos XVIII e XIX. 2015. 219p. Dissertação (Mestrado em Ciências Sociais). Universidade Federal de Uberlândia.

MORI, Robert. Uma questão de terras: Índios e Geralistas no Sertão da Farinha Podre - Séculos XVIII e XIX. Crítica e Sociedade: revista de cultura política, Uberlândia, v. 7, n. 1, 2017.

MOURA, Antônio de Paiva. Campo das Vertentes: sua origem e sua característica. As Minas Gerais: asminasgerais.com.br, acesso em 03 de fevereiro de 2016.

PARANHOS, Paulo. Primeiros núcleos populacionais no Sul das Minas Gerais. Histórica - Revista Eletrônica do Arquivo Público do Estado de São Paulo (Arquivo Público do Estado de São Paulo), no 7 (dezembro 2005).

PEIXOTO, Afrânio. História do Brasil. Transcrição para eBook 2008 (www.ebooksbrasil.org): Digitalização da $2^{a}$ edição em papel. Biblioteca do Espírito Moderno - Série 3. ${ }^{\text {a }}$ - História e Bibliografia. Cia Editora Nacional - 1944

PORTUGAL, Arquivo Histórico Ultramarino de Lisboa. Catálogo de Documentos Manuscritos Avulsos Referentes à Capitania de Goiás Existentes no Arquivo Histórico Ultramarino de Lisboa. Lisboa, s.d.

RIO PARANAÍBA, Prefeitura de. História: Nossa Cidade. Disponível em: <http://www.rioparanaiba.mg.gov.br/historia.htm>. Acesso em 22 de fevereiro de 2017.

ROCHA, Joaquim José da. Mappa da Comarca do Rio das Mortes pertencente a Capitania de Minas Geraes que mandou descrever o Illustrissimo e Excellentissimo Senhor D. Antonio de Noronha Governador e Capitam General da mesma Capitania, segundo as mais exactas informaçoens. Anno de 1777. Capitania de Minas Geraes. 1777. 
ROCHA, Joaquim José da. Mappa da Comarca do Sabara pertencente a Capitania de Minas Geraes. Capitania de Minas Geraes. 1777.

ROSA, Ernesto. Sertão da Farinha Podre. Araxá, Minas Gerais: Erosan, 2011.

SANTOS, Milton. Metamorfoses do Espaço Habitado, fundamentos Teórico e Metodológico da Geografia. ISBN 85-271-0068-1. São Paulo: Hucitec, 1988.

SANTOS, Milton. Território, Globalização e Fragmentação. São Paulo. Hucitec, 1994.

SANTOS, Milton. A Natureza do Espaço. Técnica e Tempo. Razão e Emoção. São Paulo: Hucitec, 1996.

SANTOS, Milton. As cidadanias mutiladas. In GERNER, Julio (Ed). O Preconceito. São Paulo, Imprensa Oficial do Estado, 1996/1997.

SANTOS, Milton. O Dinheiro e o Território. Conferência de inauguração do Mestrado em Geografia da Universidade Federal Fluminense, 1999.

SANTOS, Milton. Para que a geografia mude sem ficar a mesma coisa. RA'E GA, Curitiba: Editora UFPR, n. 9, 2005. p. 125-134.

SÃO PAULO, Archivo do Estado de. Publicação Official de Documentos Interessantes para a História e Costumes de São Paulo - Diversos. Vol. IV. São Paulo: Typographia da Companhia Industrial de São Paulo, 1896.

SILVA, Paula Junqueira da, e Maria Geralda de ALMEIDA. TERRITORIALIDADE E DESTERRITORIALIDADE: os assentamentos rurais e a reterritorialidade do campesinato no espaço agrário do Cerrado mineiro. V CONGRESSO DE CIÊNCIAS HUMANAS, LETRAS E ARTES. Pilar - Ouro Preto - Minas Gerais - Brasil: UFOP, 2001.

SOSTER, Sandra Schmitt. Missões Jesuíticas como Sistema. 2014. 248p. Dissertação (Mestrado em Arquitetura e Urbanismo). Universidade de São Paulo - São Carlos.

SOUZA, Bruno Augusto de, Ednahn Veríssimo Andrade da SILVA, e Fernando Silveira LEÃO. Região, Regionalismo e Regionalidade: o Movimento. GeoAtos - Revista Geografia em Atos, no 13 (Departamento de Geografia da FCT/UNESP) 1 (2013): 107117.

USP, Laboratório de Estudos de Cartografia Histórica (LECH)/. Cartografia Histórica. 02 de 04 de 2015. www.mapashistoricos.usp.br.

WDL, World Digital Library. World Digital Library. 12 de 05 de 2015. http://www.wdl.org/pt/ 